\title{
The Politics of Order in Informal Markets: Evidence From Lagos
}

\section{Citation}

Grossman, Shelby. 2016. The Politics of Order in Informal Markets: Evidence From Lagos.

Doctoral dissertation, Harvard University, Graduate School of Arts \& Sciences.

\section{Permanent link}

http://nrs.harvard.edu/urn-3:HUL.InstRepos:33840713

\section{Terms of Use}

This article was downloaded from Harvard University's DASH repository, and is made available under the terms and conditions applicable to Other Posted Material, as set forth at http:// nrs.harvard.edu/urn-3:HUL.InstRepos:dash.current.terms-of-use\#LAA

\section{Share Your Story}

The Harvard community has made this article openly available.

Please share how this access benefits you. Submit a story.

\section{Accessibility}


(C) 2016 - Shelby Grossman

All rights reserved. 
Dissertation Advisors: Robert Bates

Catherine Duggan, Jeffry Frieden, James Robinson

Shelby Grossman

The Politics of Order in Informal Markets: Evidence from Lagos

\begin{abstract}
Property rights are important for economic exchange, but in much of the world they are not publicly provided. Private market organizations can fill this gap by providing an institutional structure to enforce agreements, but with this power comes the ability to extort from the group's members. Under what circumstances will private organizations provide a stable environment for economic activity? Using original survey data collected from 1,878 randomly sampled traders across 269 markets, 68 market leaders, and 55 government revenue collectors across 57 local governments in Lagos, Nigeria, along with market case studies, I find that strong markets maintain sophisticated institutions to support trade not in the absence of government, but rather as a response to active interference. I argue that market organizations develop and enforce pro-trade institutions when threatened by politicians they perceive as predatory, and when the organization can respond with threats of its own. Under such a balance of power, the organization will not extort because it needs the support of the traders it represents in order to keep threats credible.
\end{abstract}




\section{TABLE OF CONTENTS}

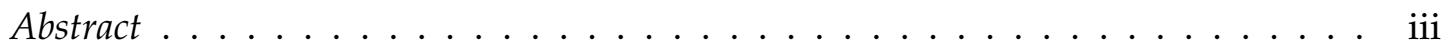

Acknowledgments ............................... vi

1. Explaining Private Order Institutions . . . . . . . . . . . . . . . . . . I

1.1 The argument: How threats of state interference sustain private order institutions ........................ 4

1.2 Additional factors that may shape private good governance . . . . . . 14

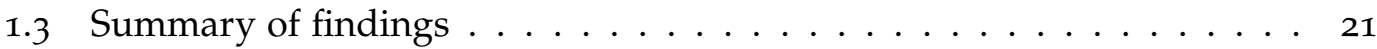

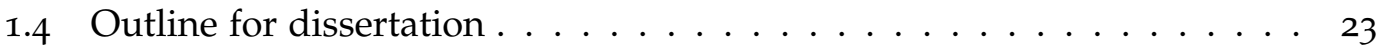

2. Conceptualizing Market Associations for Empirical Analysis and Situating the Case 27

2.1 What is a market association? . . . . . . . . . . . 27

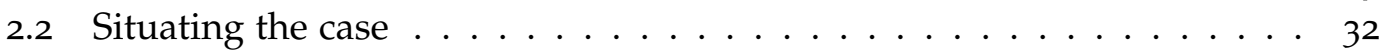

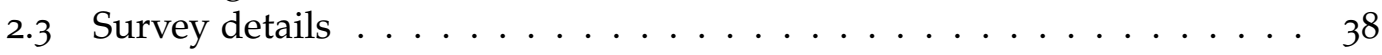

2.4 Conclusion . . . . . . . . . . . . . . . . . 45

3. Case Studies of Markets with Different Institutions . . . . . . . . . . . . . . . 46

3.1 An orderly market . . . . . . . . . . . . . . . . . 48

3.2 A failing market governed by a predatory market association . . . . . 55

3.3 A failing market governed by a weak market association . . . . . . . . . 65

3.4 Why not leave? And why join in the first place? . . . . . . . . 70

3.5 Conclusion ......................... 71

4. Testing the theory with hundreds of Lagos market associations . . . . . . . . . . . . . 73

4.1 Measuring variables . . . . . . . . . . . . . . . . 75

4.2 Descriptive statistics . . . . . . . . . . . . . . . . . . . . 79

4.3 Results ........................ 80

4.4 Assessing additional factors that may shape private governance . . . . . 88

4.5 Conclusion ............................ 99 
5. Testing the Theory with the Market Men and Women Association . . . . . . . . . . . 101

5.1 Introduction . . . . . . . . . . . . . . . . . 101

5.2 MMWA outcomes: Extortion and institutions . . . . . . . . . . . 103

5.3 Market Men and Women Association-state balance of power . . . . . . . 109

5.4 Tracing market women strength . . . . . . . . . . . . . . 112

5.5 Evidence contrary to presence of state-MMWA collusion . . . . . . . . 121

5.6 Conclusion . . . . . . . . . . . . . . . . . 124

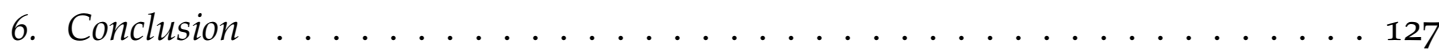

6.1 The myth of spontaneous order . . . . . . . . . . . . . 127

6.2 Summary of argument and findings . . . . . . . . . . . . . . 129

6.3 Broader implications . . . . . . . . . . . . . . . . . 131

$\begin{array}{ll}\text { Appendix } & 134\end{array}$

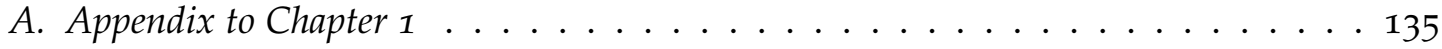

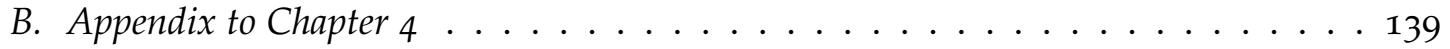

Bibliography. . . . . . . . . . . . . . . . . 140 


\section{ACKNOWLEDGMENTS}

I want to thank each of my committee members - Robert Bates, Catherine Duggan, Jeffry Frieden, and James Robinson - for being excited about the importance of my dissertation topic over the past few years. The excitement you all conveyed in meetings motivated me in my research and writing.

Bob, thank you for helping me realize when I had found an important dissertation topic. You pointed me to big theoretical readings early on that allowed me to put my narrow topical interests into perspective and assess how what I saw in the field matched up to the state of existing research. Additionally, thank you for honestly pointing out ways in which I could improve as a scholar throughout my time in graduate school. This type of feedback is hard to come by, and I was always grateful for it.

Jeff, you made my dissertation stronger by forcing me to think through the logic of every assertion I made. Thank you for being positive and encouraging and accessible.

James, thank you for pushing me to always think through the political dimensions of trade, and for always being so confident that there was an important political dimension to be uncovered.

Catherine, thank you for forcing me to be precise in the way I portrayed existing scholarship, and for sharing insights from your own research into the political economy of firms in Nigeria.

Thank you to Chris Woodruff and the Private Enterprise Development in LowIncome Countries initiative for funding both surveys used in this project. Chris, thank you also for welcoming me, as a political scientist, into your PEDL community. 
Thanks to Gwyneth McClendon for providing thoughtful feedback on my work, and for answering a variety of professionalization questions over the years and never making me feel bad for asking.

Jonathan Phillips, thanks for reading everything I sent you so carefully and providing detailed and supportive feedback at many stages of this project. Thanks to friends and running group members Julie Faller and Rakeen Mabud. Our chats sensitized me to issues of exclusion that now inform how I see the world. Thanks to Graeme Blair for introducing me to Lagos, and for making sure the way I framed this project was always compelling, clear, and polished. Diane de Gramont, thanks for sharing your insights about Lagos politics.

Meredith Startz, working with you on projects has made me realize the benefits of collaboration. I have learned so much from you, and you have made me a more careful researcher.

Dylan Groves, thank you for the energy and humor you brought to the first Lagos Trader Survey. Hakeem Bishi, thanks for the professionalism and attention to detail that you brought to the second Lagos Trader Survey. To both of you: your positive attitudes have been contagious.

To my dissertation group, Jen Pan, Amanda Pinkston, Molly Roberts, Chiara Superti, and Vanessa Williamson: you each gave me important feedback on framing at every step of this project. As importantly, I learned so much from following the development of your projects.

Amanda, graduate school was a happy and intellectually exciting time of my life because of you. Thank you for talking through ideas with me, spending time thinking through my challenges, and listening to my fieldwork adventures. I'm grateful for your friendship. 
Thanks to my brother for paying my cell phone bill during graduate school and allowing me access to his Netflix and Amazon Prime accounts. Thanks to my parents for calling my bank every time my debit card was copied in Nigeria, for much needed airport pick ups after fieldwork trips, and for helping me move at least six times.

Finally, thanks to the traders, market leaders, and government officials who chose to trust me and speak with me for this project. In particular, thanks to Edwin Nnamdi Onye, Alhaja Marsha, and two traders from Ladipo Spare Parts Market and a former market manager who will go unnamed. I hope you all feel that this dissertation captures something approximating the realities of market governance in Lagos. 


\section{EXPLAINING PRIVATE ORDER INSTITUTIONS}

Oke-Arin and Ladipo, two of the largest markets in Lagos, Nigeria, are similar in many ways. Both have around 1,00o traders, are ethnically homogenous, and focus on high-end products (wine in Oke-Arin and spare car parts in Ladipo). The private traders' associations that lead both markets are exceptionally strong, holding regular well-attended meetings and enforcing leaders' decisions about market management. But this is where the similarities end. Oke-Arin is a model of good governance. The association uses its strength to support and enforce a wide variety of pro-trade institutions, even when those impose short-run costs on members or leaders. They handle customer complaints impartially, sometimes confiscating sub-standard wine from traders' shops, and adjudicate disputes between traders to maintain order in the market. In contrast, the association in Ladipo, the spare parts market, uses its strength to extort from traders inside the market. They created a pernicious "toll gate fee" that customers and traders must pay every time they enter, and traders say the leaders "eat and eat," a reference to using these fees for personal benefit. The association spreads humiliating rumors about traders who threaten their policies. They turn traders against each other, creating a hostile and opaque business environment.

The underlying dynamics explaining divergent outcomes in these two markets are not obvious. Existing explanations for private good governance focus on the size and diversity of the group, but Oke-Arin and Ladipo are similar on these dimensions. In addition, both associations are strong in the sense that they are able to control the 
market's internal affairs. Yet one association uses its strength to promote trade and the other uses its strength to predate.

This puzzle speaks to an enduring question: how does economic activity take place in states where the rule of law is weak - states where laws are unclear and agreements unevenly and inefficiently enforced? A large literature spanning from the determinants of trade in medieval Europe to how prison gangs enforce illegal drug contracts argues that private groups can provide institutions that support contractual trade (Duggan, Forthcoming; Ellickson, 1991; Gambetta, 1996; Greif, 1993; Milgrom, North and Weingast, 1990; Richman, 2006; Skarbek, 2014). With the power to privately enforce agreements, though, comes the power to extort, and indeed many private groups predate on their members.

Under what conditions, then, will private groups use their power to promote trade? I approach this question using original survey and case study data collected in hundreds of markets in Lagos, Nigeria. Lagos markets are uniquely well-suited to provide insight into these issues on a number of dimensions. First, Lagos State has a sizable population and 57 local governments. This means that there are a large number of markets and a great deal of local variation in factors affecting market governance, while macro conditions are held constant. Second, I am able to observe a sometimes elusive counterfactual - markets that fail - because many are on land that is designated for markets, and alternative use of the land is not normally possible, allowing bad markets to hold on longer than they might in other contexts. Third, some markets have associations that govern for life, while others have associations with term limits. This allows me to assess the role of a long time horizon, which has been theorized to align incentives between a group leader and group members 
(Olson, 2000). ${ }^{1}$

In Lagos, I find hundreds of private market associations, both strong and weak. As the cases of Oke-Arin and Ladipo show above, however, strength does not necessarily translate into good governance. Instead, I find that private good governance arises from the interaction between a strong market association and an interventionist local government. I argue that interventionist governments - governments that aim to intervene in societal groups, typically to extract revenue - incentivize strong private associations - associations that can control the group's internal affairs - to promote trade. In contexts where the rule of law is weak, groups perceive interventionist governments as predatory. In the face of this threat, an association's ability to push back against the government is dependent on its ability to mobilize group members, which motivates it to support rather than extort from them. In addition, an interventionist government will incentivize an association to reduce internal disputes, as disputes provide opportunity for meddling public officials to involve themselves in market affairs. Associations limit disputes by preventing group member opportunism and ensuring group members avoid known dishonest individuals based outside the group, which supports trade.

This is not an argument about the state directly organizing the economy, nor is it an argument about the economy growing when the state stays out of market affairs. Rather I suggest the threat of the government involving itself in private groups compels groups to maintain order. In contrast to accounts of private order that suggest private institutions substitute for public institutions (e.g. McMillan and Woodruff, 1999), I argue that as the government grows, private institutions grow. Elinor Ostrom argues the government can help enable private ordering by offsetting the costs of

\footnotetext{
${ }^{1}$ I use the terms "group association" and "group leaders" interchangeably.
} 
monitoring shared resource usage (1990), and here I present an additional channel government threats generating defensive pro-trade institutions - through which the government shapes group order.

Conventional wisdom suggests that less political interference would be better for market order in a developing country context, but my argument predicts the opposite. Using original survey data I present evidence that strong market associations are less likely to extort in the face of state interference. With three market case studies I highlight the mechanisms through which threats of state interference enable private ordering, and document how predatory associations can persist.

\subsection{The argument: How threats of state interference sustain private order institutions}

An association that governs a group - whether public or private - that is strong enough to protect property rights and enforce contracts is also strong enough to confiscate the wealth of its members, what Barry Weingast calls "the fundamental political dilemma of an economic system" (1995, p. 1). A large, diverse, and interdisciplinary literature has described the characteristics that define successful selfgoverning organizations in the absence of impartial public institutions that protect property rights. However, this body of work rarely grapples with when, why, and how some groups succeed in developing these institutions while others do not. I address this gap in the literature by exploring what incentivizes an association to invest in pro-trade institutions, when alternatively, they could use their strength to predate.

The emergence of pro-trade institutions is not a foregone conclusion, for a variety

of reasons. A novel contribution of my argument is to highlight that the short-term 
costs of such institutions are substantial to an association. Specifically, two types of institutions matter for supporting contractual trade: information sharing and enforcement institutions. With strong information sharing institutions, group members will have information about the past behavior of potential trading partners and will be able to avoid entering into risky transactions with dishonest individuals (e.g. Greif, 2006; Milgrom, North and Weingast, 1990). Enforcement institutions enforce agreements (e.g. Milgrom, North and Weingast, 1990), punish dishonest outsiders (through boycotts), and punish opportunistic insiders through in-group policing (e.g. Fearon and Laitin, 1996; Habyarimana, 2009) impartially and efficiently, and these rulings have high compliance rates (e.g. Richman, 2006).

Both types of institutions have costs from the perspective of the leaders, who must either motivate members to share information about people who have cheated them - a difficult endeavor when group members are in competition with each other and individually have little incentive to share such information - or occasionally make rulings in disputes that go against the short-term interests of group members. I note these costs to emphasize that only under very specific conditions where benefits to a group association outweigh costs will these institutions be observed. Many studies either claim that group members are not in fact in competition with each other (Greif, 2006) or ignore the role of competition, focusing only on what happens once collective problems have been overcome. $^{2}$

Further, the success of a group depends on internal governance. What prevents group leaders from simply extorting from their members? Under what conditions are group leaders incentivized to serve interests outside their own? When a group leader

\footnotetext{
${ }^{2}$ An exception here is Frye (2000) who argues that low tax rates can facilitate information sharing within a group, as the consequences of a member sharing information with the government about another member's volume of trade are less severe.
} 
could punish an opportunistic group member for cheating an outsider, what prevents the leader from accepting a bribe from the member to not enforce the punishment? The literature leaves such important questions unanswered. The few studies that have tried to address this focus on private constitutions and internal systems of checks and balances (e.g. Leeson, 2007). But these explanations are incomplete. What limits internal collusion? What constrains a predatory leader from using the powers of incumbency to buy off or slander those who oppose her rule?

In contrast to much of the existing literature on private groups which suggests that private institutions substitute for public institutions (e.g. Greif, 1993; Richman, 2006) I argue that interventionist governments can spawn and make more critical private good governance; private associations will predate without public institutions that force them to behave otherwise. I argue that two types of institutions, property rights institutions (which protect individuals from extortion), and contracting institutions (which enable contractual agreements between individuals) are most likely to be observed within organizations when the association is strong and confronted by threats of state interference. ${ }^{3}$

I define strong associations as group leaders who can control internal group affairs. These are associations with the de facto right to adjudicate disputes that occur within the group. I make the assumption that these associations, composed of one or more leaders, are self-interested. They aim to maximize their income, which results from maintaining their position and power to tax group members.

Interventionist governments are those with a motivation to intervene in organized societal groups, typically to extract revenue from groups. This concept is distinct from concepts like government capacity which include components of social control, such

\footnotetext{
3 The distinction between property rights and contracting institutions was made by Acemoglu and Robinson (2005) and North (1981).
} 
as the state's effectiveness in taxation, coercion, and appropriation of resources (e.g. Geddes, 1994; Migdal, 1988). The concept of government interventionism is unrelated to societal strength, which for the purposes of this study is a distinct explanatory variable. A government can be interventionist according to my definition even if it does not succeed in extracting revenue, which might be the case when up against a very strong association. ${ }^{4}$ In addition I make no assumptions about whether politicians are predatory or not, which I use to mean extracting revenue that is not used to benefit the public (Evans, 1989), a process that is often (though not always) characterized by unpredictability (Shleifer and Vishny, 1993). The point is simply that in a context where governments do not have a developmental track record, groups perceive interventionist, activist, governments as predatory, and their goals as contrary to group interests. I further assume that these group and government attributes are relatively "sticky," or slow to change.

I argue that mutual threats between the group and government enable group leaders to maintain order. Interventionist governments can threaten to increase group member taxes or even threaten group viability, perhaps by threatening the group's ownership status over assets. When an organization is strong, these government threats motivate the associations to not extort and invest in other pro-trade institutions such as information sharing.

Why will these threats limit private extortion? A strong association wants to keep an interventionist government out of the group. The association's threats against the state, however, are credible only if the association can mobilize members to protest or vote as a block or otherwise collectively sanction politicians (Bates and Lien, 1985). And mobilization requires support. To obtain this support, the association will not

\footnotetext{
4 Governments of course may aim to intervene in some types of societal groups but not others, but for simplicity in this paper I conceptualize governments as being interventionist or not.
} 
extort. This part of the argument has parallels to the state-building literature. For Tilly (1992), a group leader's ability to push back against an external threat requires support from group members, incentivizing negotiation and exchange between the group leader and group members, and for Centeno (2003), only under certain conditions - some existing level of organizational capacity - will external threats promote institution building. ${ }^{5}$

Why will the threat of state interference encourage the association to facilitate information sharing? Interventionist governments motivate the association to keep its house in order. Disputes provide an opportunity for public officials to intervene in a group. For example, police might come into an area to deal with an altercation. If an association permitted opportunistic behavior, such as allowing a group member to sell sub-standard products, public officials could exploit a customer complaint as an opportunity to intervene in the market and extract revenue. By eliciting and sharing information about dishonest trading partners, the association limits disputes, limiting openings for government extortion, which can threaten the influence of group leaders. It is important to note, however, that association strength is a necessary condition. State interference will not lead to information sharing when the association is weak.

The notion of state-society struggles promoting trade is distinct from descriptions of partnerships between the state and societal groups that are seen in research on coproduction (Mitlin, 2008) and on how developmental states are effective in promoting economic growth (e.g. Doner, 1992; Evans, 1995). Those who argue that under a very

\footnotetext{
5 The mutual threat argument has parallels to Oliver Williamson's theory that two actors can provide each other with hostages to facilitate contractual trade (1983), and to arguments that a balance of power between the state and businesses can shape tax rates (Luong and Weinthal, 2004). There are also parallels to Duggan (Forthcoming) who argues that private lending markets grew when the state could check their power, namely by preventing lenders from stealing from their clients. This led potential borrowers to trust lenders. This argument also builds on work that suggests external threats, such as police repression, can motivate group solidarity (Thachil, 2015).
} 


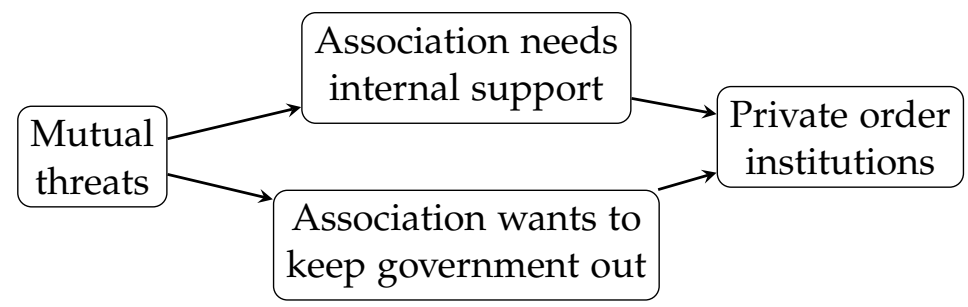

Figure 1.1: Two mechanisms that connect mutual threats with private order.

specific condition - when the state is developmental - close cooperation between the state and business associations is critical for growth, tell us little about the conditions under which localized growth would be observed in non-developmental states.

However, I am of course not the first to argue that a balance of power between the state and society can lead to economic growth. Karl Polanyi, for example has proposed that there are enormous perils to untempered market liberalism (1944). David Kang has argued that a balance of power between the state and businesses can constrain corruption (2002). My contribution is to introduce two mechanisms through which this balance of power can affect trade, shown in figure 1.1.

In Governing the Commons Ostrom observes that collective action problems in water basin governance were overcome in the face of an external threat from the government - namely an impending lawsuit that threatened to alter the group's status quo (1990). But Ostrom ultimately focuses on the importance of public officials in offsetting the costs of common resource governance by assisting with resource use monitoring. I argue that in contexts where the rule of law is weak the government does not typically offset resource governance costs, and rather attention should be focused on the role of the state as an external threat (or not).

Ostrom, though, is one of few (along with Frye (2000)) who have considered the origins of private institutions. The vast literature on private governance describes 
only how these groups function, not what makes trade-promoting organizations more likely. My contribution is to show that in developing countries, even when the government is not offsetting the costs of group governance, politicians are still incentivizing the creation of such institutions. In short, this is an argument about the conditions under which a self-governing organization will 1) not itself extort, and 2) be incentivized to provide the costly and important services that enable trade.

Table 1.1: Predictions of the argument. This table shows predicted levels of private extortion and pro-trade institutions (e.g. information sharing).

Interventionist government Non-interventionist government

\begin{tabular}{|l|l|l|}
\cline { 2 - 3 } Strong association & $\begin{array}{l}\text { Private extortion: Low } \\
\text { Pro-trade institutions: High }\end{array}$ & $\begin{array}{l}\text { Private extortion: High } \\
\text { Pro-trade institutions: Low }\end{array}$ \\
\cline { 2 - 3 } Weak association & $\begin{array}{l}\text { Private extortion: Ambiguous } \\
\text { Pro-trade institutions: Low }\end{array}$ & $\begin{array}{l}\text { Private extortion: Ambiguous } \\
\text { Pro-trade institutions: Low }\end{array}$ \\
\cline { 2 - 3 } & \multicolumn{2}{|l}{}
\end{tabular}

From this discussion, the following testable predictions emerge. Private extortion should be low and pro-trade institutions (such as information sharing) should be present in groups with strong associations that face threats of state interference. Given that pro-trade institutions are costly for the association, they require association will and ability to sustain. I expect we will not observe pro-trade institutions in any other case. While I expect that strong associations will extort in the absence of a check on their power, it is unclear how associations will behave when weak. Some weak associations are largely absent, and these may not extort. Others may be weak but make half-hearted attempts at low-level extortion. 


\subsubsection{Public extortion}

Though not the focus of this dissertation, I expect efforts to constrain public extortion to go hand-in-hand with the other pro-trade institutions discussed above. Strong associations, in the presence of an interventionist government, will mobilize to protect the group from public extortion, essentially shaping government policies with regard to the group. A variety of conceptual challenges, however, conspire to make this a variable that is difficult to predict and measure. ${ }^{6}$

First, scholars are interested in state extortion largely due to its effects on trade. While the standard academic definition of extortion is illegal demands for property backstopped by threats, in developing countries individuals use extortion to mean this and more. Sometimes, in fact, the illegal nature of demands is perceived as inconsequential. Other aspects of state fee collection may be more pernicious.

In developing countries, extortion may be used to mean one or more of the following: 1) unpredictability of tax collection, 2) disparity in the tax rate across individuals, 3) government discretion in when and what is charged, 4) when the state breaks agreements with associations about taxes, 5) theft - traders will say they were extorted if someone pretending to be a government official collected taxes from them, ${ }^{7}$ and 6) the amount of taxes; taxes that are seen as objectively too high are considered extortion. Notably, none of these are conceptions related to state performance. This could be because of a perception that taxes are never used to benefit society. Collecting taxes and not using them to benefit the public is simply taxation.

But when a societal group faces state extortion, it will not face extortion in all

\footnotetext{
6 The discussion on extortion that follows has been informed by brainstorming with Catherine Duggan as part of an ongoing coauthored project on extortion.

7 I consider this state extortion as the state could invest effort in arresting these individuals, or instituting policies to allow taxpayers to ensure they are paying a reputable representative of the state.
} 
of these forms. For example, in some associations government officials may change the tax rate week to week (conception $\#_{1}$ ) but the amount charged is always uniform across group members (conception \#2).

As such, efforts to constrain extortion would manifest themselves in different ways. This makes it difficult to predict what sorts of group institutions should be expected. In this project I will consider the actual outcome - extortion - as opposed to the group institutions to constrain extortion, as the former is easier to observe. However I will only look at this outcome in the case study data, due to the challenges in developing theoretical expectations for when we should (for example) observe taxation that is unpredictable but not perceived as too high.

Table 1.2: Predictions of the argument for public extortion. This table shows predicted levels of public extortion.

\begin{tabular}{|ll|l|}
\multicolumn{2}{c}{} & \multicolumn{2}{l}{ Interventionist government } & Non-interventionist government \\
\cline { 2 - 3 } Strong association & Low & Ambiguous \\
\cline { 2 - 3 } Weak association & High & Ambiguous \\
\cline { 2 - 3 } & &
\end{tabular}

Public extortion, in any form, should be low for group members under strong associations that face threats of state intervention. Public extortion should be high for groups members in weak associations under the jurisdiction of an interventionist local government. The expectations are ambiguous in the other two cases. In non-interventionist governments low-level bureaucrats may (or may not) engage in unsanctioned extortion, and it is unclear how a strong, predatory association would respond to this. 


\subsubsection{Collusion}

The possibility of association-politician collusion complicates the argument presented here. Collusion with the goal of increasing rents from group members is theoretically most likely in interventionist governments, as non-interventionist governments are definitionally less interested in raising revenue. In these interventionist governments collusion is possible with strong associations that might be interested in the short-term gains of joint predation. Existing research suggests collusion exacerbates private predation: Marx et al. (2013) have shown that there are higher levels of private leader predation when public officials and group leaders collude in slums, and LeBas (2013) shows that private militias become more predatory when they partner with the state.

To the extent that collusion is occurring in this context it should downward-bias the estimates in section 4.3.4. Collusion would manifest as private predation in the strong-interventionist scenario, pushing down the estimate on the absence of private extortion. For this reason, the possibility of collusion does not threaten the findings.

However, these points leave two questions unanswered: first, how common should collusion be? Research on collusion finds that two factors enable collusion: frequency of interactions between parties and the ability to detect defections from collusive arrangements (Ivaldi et al., 2007). The former condition is certainly met for most associations in developing countries. Interactions with local politicians tend to be common. However, there may be serious constraints on the ability to detect defections. In this context, defection would involve an association under-reporting collected fees to a local politician. It would be very difficult for state officials to ascertain if this were happening. Associations have high levels of information about conditions and happenings in their group, information that is challenging for outsiders to obtain. When 
firms collude they develop sophisticated monitoring strategies to detect cheating; I expect the hurdles to these strategies to be substantial in this context.

Second, even if collusion is rare, when will it be observed? Through a close examination in chapter 3 of an association that colluded with a local government, I inductively develop an argument for the conditions that make collusion more likely.

\subsection{Additional factors that may shape private good governance}

In this section I will assess the theoretical plausibility of additional explanations for private good governance. The design of this project allows me to control for a variety of variables that could affect private governance, such as the type of regime that the group is located in. I will focus here first, on other potential group-level explanations, such as the heterogeneity of group members and the time horizon of group leaders. I will also discuss the plausibility of individual-level explanations that some have posited may obviate the need for group institutions. Last I will assess other explanations related to the role of public institutions. In chapters 3 and 4 I assess these explanations empirically.

\subsubsection{Other group-level explanations}

\section{Can individuals sort into groups?}

The argument rests on the assumption that group members aim to maximize their income, which results in part from whether they are part of a group that has pro-trade institutions. A potential criticism of the argument is that successful traders select into trade-promoting markets, and this explains the persistence of market order, not the mutual threat argument. I expect, however, that there will be substantial frictions to sorting into trade-promoting groups. This is because 1) group membership is 
relatively sticky, making it difficult for individuals to frequently switch group membership, and 2) outsiders have highly incomplete information about the conditions in the group before joining. These assumptions may not hold for all groups everywhere, but I expect they will hold for many groups we care about in developing countries, such as trade unions or business associations.

\section{Can traders sanction or overthrow predatory leaders?}

What prevents group members from overthrowing a predatory group leader, or less severely, sanctioning a predatory leader? Here I address the alternative explanation that group members should be able to pressure their leaders to not extort. There are a number of ways this could work. First, perhaps logics for group monitoring of public officials apply to group member monitoring of group leaders. For example when a leader is embedded in the community she serves her desire for social acceptance in other spheres of her life can motivate good governance (Tsai, 2007; Uzzi, 1996). In many urban contexts, though, such embeddedness does not exist. Group leaders do not interact with members in any non-group context. A second possibility is for group members to partner with third parties to sanction their leaders (analogous to the logic in Markus (2012)). This would require a group overcoming the collective action problem in the absence of their existing leader, no easy feat. As Bates has observed, "[t]he demanders of institutions cannot supply them because institutional innovations themselves constitute collective dilemmas" (1988). Third, there are compelling arguments about how group cooperation is facilitated by sanctioning those who act opportunistically (e.g. Miguel and Gugerty, 2005). While this literature lacks substantive accounts of this sanctioning, leaving unanswered important questions about how and when such sanctioning occurs, almost certainly a leader is 
required to initiate these decisions. Through what mechanism, then, would a group sanction their leaders? Such sanctioning is possible to imagine, but I expect it to be unusual in practice.

If sanctioning is difficult, the obstacles to mutiny are enormous (Leeson, 2007). Mutiny is, first and foremost, a collective action problem. Collective action problems are normally overcome with the guidance of a leader, but in cases of potential mutiny the recognized leader is definitionally not going to be part of such collective efforts. Normally a new leader must be identified, which, as noted above, is not straightforward. Further, mutiny is exceptionally risky. Group members must trust that a large number of fellow group members will follow through on a promise to mutiny. But paradoxically, in groups where mutiny is desirable a predatory group leader has probably cultivated distrust among group members. Finally, in many-though not all-groups in developing countries, the group leader has state recognition. This can make mutiny even more difficult, depending on the extent of such recognition. In short, while group sanctioning of a leader and mutiny are theoretically possible, these actions should be empirically rare.

\section{Is the long time horizon of a leader sufficient for private order?}

Another explanation focuses on the time horizon of the leader. In many organizations group leaders hold their position for life. Is this long time horizon sufficient to align incentives between the leader and group members as has been theorized by Mancur Olson (2000)? After all, if group leaders aim to maximize their income, which is a function of fees that are collected from group members proportional to the amount of wealth generated in the group, wouldn't greater group order increase group-derived leader profits over the long-term? In fact, a long time horizon may not 
be sufficient to constrain short-term temptations to extort. Leaders can have conflicts of interest, such as other businesses and income streams, that may encourage them to act on short-term opportunities at the expense of long-term group revenue growth (Ostrom, 1990).

Additionally, in many developing country contexts, it is unclear how any individual could ever have a long time horizon. High levels of political uncertainty and the prospect of natural and human-influenced disasters may make it unrealistic for any individual to assume she will be in a position for an extended period of time.

\section{Is group homogeneity sufficient for private order?}

In the absence of a strong and predictable legal environment, and when traders have no fixed assets to be used as collateral, many have argued that trust is critical for enabling trade (e.g. Fafchamps, 1996). Studies have shown that shared ethnicity can create such trust and promote cooperation (Habyarimana, 2009) and enable economic growth (Easterly and Levine, 1997; Robinson, 2015).

One might, then, think that more group homogeneity would be associated with more cooperation, which might be associated with better trade outcomes. However, when thinking about trade unions or business associations, group members are often in competition with each other. Because of this, even in small groups it is unlikely members will cooperate organically simply because they share an ethnic identity. Additionally, unstructured cooperation is often not possible with large groups that have hundreds of members. These large groups require leaders and rules that are impartially and efficiently enforced.

Perhaps, though, group leaders who share the ethnicity of group members feel more affinity toward them and are then less likely to predate. There is evidence, 
however, that group leaders can also capitalize on group homogeneity to facilitate extortion and consolidate power (Acemoglu, Reed and Robinson, 2014; Berman, 1997). I expect that group homogeneity will not be associated with private order institutions.

\subsubsection{Individual-level explanations}

Is shared ethnicity with trading partners a substitute for private order?

What if, though, individuals could rely on shared ethnic identity with suppliers and customers to grow her business? The ability of traders to get products on credit from their suppliers and feel comfortable selling to customers on credit are critically important outcomes in many developing countries. In Africa, access to finance is a major constraint for $37 \%$ of all firms. Supplier credit finances virtually the same amount of working capital as bank loans (World Bank, 2007). Similarly, in contexts where customers do not always have funds to pay for products immediately, being able to assess when it is smart to sell on credit is critical for expanding economic activity. I proposed that group institutions can facilitate these contractual transactions, but what if individual relationships can substitute?

In the case at hand, physical marketplaces, I do not expect shared ethnicity to facilitate these contractual transactions between traders and suppliers and customers. There are two reasons for this. First, for Habyarimana et al. (2009) shared ethnicity leads to cooperation because of threat of social sanction for opportunistic behavior. In dense urban environments, where traders may not live in the same neighborhood that the market is in, it is unclear how simply sharing membership in one of a few large ethnic groups would make social sanction easier. Second, the market trader context is different than the context in many studies of ethnicity and trade. All of the traders under study here are easily findable. They have physical, permanent shops 
in physical, permanent markets. In a sense, this case allows us to control for the "findability" mechanism that Habyarimana et al. find does connect shared ethnicity and trust. While this case will not allow me to examine the generalizability of their finding as all traders are findable, I expect that in this context there will not be a relationship between shared ethnicity and contractual trade.

\section{Can relational contracting substitute for private order?}

Economists often assume that relational contracting - "informal agreements sustained by the value of future relationships" - can enable contractual trade in the absence of access to impartial public dispute resolution mechanisms (Baker, Gibbons and Murphy, 2002). Long-term relationships, it is theorized, can enable reputational mechanisms. A nascent literature is starting to carefully examine the conditions that must be met to enable relational contracting. For example, MacLeod (2007) notes that an individual who cheats another must expect that their reputation will be harmed. One study suggests that it may be cheaper to incur monitoring costs over investing in relational contracting (Taylor and Wiggins, 1997).

I expect that relational contracting will be rare for two reasons. First, relational contracting assumes a buyer can either 1) distinguish between seller malevolence and events that occurred outside the control of the seller, or 2) that events outside the control of the seller are rare. Both of these assumptions must be questioned in a developing country context where it is very difficult to get information about events that may or may not have occurred. This is in part due to the sheer number of actors involved in any given transaction. A seller may say that products got water damaged because of a shipping agent who didn't care for them properly. It will be difficult for the buyer to ascertain whether this is true, or whether the seller tried to offload bad 
products on the buyer. When these sorts of events are rare, you trust that they were indeed outside the control of the seller. But when these events happen frequently as they do in many developing countries - it becomes exceptionally hard to build a reputation.

Second, reputation has a greater effect on trade when information is shared. In competitive business environments, where individuals may benefit from their competitors being cheated, this is not to be assumed. Indeed it is the group institutions I have described that may be critical to enable this information sharing.

\subsubsection{Other explanations that emphasize public institutions}

Does variation in the quality of public institutions affect market order?

My argument about the role of government interference in private order is agnostic to the intent of the interference. The government could be interfering to predate, or interfering to raise taxes that will be used to build a road. But what if what matters is more the quality of the public institutional environment? Perhaps private predation is less likely when the group is located in a jurisdiction with stronger and more impartial public institutions. Then group members could bring complaints about group governance to politicians and bureaucrats. Knowing this, group leaders would choose not to predate.

However, in developing country contexts where the quality of governance may vary but is all below a certain threshold, the costs of inducing a government to force an association to account properly for fees is very high, and the probability of success uncertain. Moreover, it is not clear how being in a responsive government would make other group institutions like information sharing more likely. 
What if these private market associations are actually public?

What if seemingly private institutions are not that important vis a vis public institutions, or not actually private? Edwards and Ogilvie (2012) reexamine primary source documents that have been used to highlight the role of private institutions in enabling impersonal long-distance trade at the medieval Champagne Fairs, and they find that, in fact, public officials appointed the "private" fair judges. Public officials were motivated to create an impartial judicial system because the trade fairs brought in so much revenue that this reduced the incentive to sell privileges to local elites.

There is likely much truth to the argument that many private groups are more public than they appear. In societies where the rule of law is weak, the line between what is public and what is private is often blurry. And yet the idea that private associations are inherently public, and that public officials alone can be incentivized to implement trade-expansion policies, seems misguided. Edwards and Ogilvie contend that trade can expand on the assumption that public officials will act as stationary bandits, wanting to increase the size of the pie, and thus the amount of taxation. This rests on the assumption that public officials have long time horizons (i.e. with regard to job security (Levi, 1989)) and the capacity to enforce trade-promoting policies such as neutral arbitration. It seems unlikely that this was the case. At minimum, in many developing countries today the relevant leaders have exceptionally tenuous job security and it cannot be assumed that their interests are aligned with the long-term interests of traders.

\subsection{Summary of findings}

Do all strong market associations promote trade? Using survey data, I show that the answer is no. Stronger market associations are more likely to involve themselves 
in internal market affairs, but association strength on its own cannot explain variation in the provision of pro-trade institutions. With survey and case study data I show that strong market associations are more likely to promote trade when faced with the threat of state interference. I present data from the survey that better governed market associations are more likely to be politically engaged; this is consistent with the proposed mechanism of associations not extorting so as to be able to mobilize traders for political ends. Evidence from a case study support the assertion that associations will work to reduce internal disputes so that disputes do not escalate to the attention of public officials: I show that a market association punishes its own traders for selling substandard products to reduce the likelihood that a regulatory agency involves itself in the market. I find, however, that strong associations do not always promote trade in the presence of state threats. Though rare, sometimes associations collude with the state: one case suggests that associations may collude with the state when their hold on power is threatened by traders.

I find that sorting into trade-promoting markets is not frictionless: traders stay in markets for on average 7 years. While traders are more likely to stay in well-governed markets for longer periods of time than traders in poorly-governed markets, there is also evidence of traders renting shops in failing markets, not knowing that these markets are failing. I document a variety of other obstacles to relocating, including the cost of advance rent. Are markets more likely to be better governed when the market leader holds her position for life? I find that these markets are more likely to have associations that facilitate information sharing, but they are no less likely to extort from traders. Can individual-level relational contracting substitute for group-level institutions? I find that traders are less likely to receive products with defects the longer they have had a relationship with their supplier, but the size of this effect is extremely 
small. Finally, I note that there is variation in market association governance among markets within local governments. The attributes of the local government on its own do not determine the presence or absence of private order among societal groups.

\subsection{Outline for dissertation}

1.4.1 Chapter 2: Conceptualizing market associations for empirical analysis and situating the case

To test the argument I want data on both orderly and disorderly markets and the associations that govern them, across both interventionist and non-interventionist local governments. One of the primary data sources for this project is two original surveys of informal traders. This chapter focuses on theoretically important challenges in survey implementation.

First, the unit of analysis for this project is the market association, not the individual trader. I describe how I use the individual survey data to identify market associations, a task that was not as straightforward as it might appear. Second, I provide background on markets in Lagos.

Third, creating accurate sample frames for small businesses in developing countries - sample frames that include businesses that are not registered with the government - is a notoriously difficult endeavor. The predominant approach in small business surveys to generating a sample frame is to collect a list of firms from a national or municipal statistics agency, but of course these lists are censored to informal firms which definitionally do not register with the government. Some of the World Bank's Enterprise Surveys focus explicitly on informal traders. One approach these surveys use is to sample only from well-recognized informal markets, but these markets could be unrepresentative on any number of dimensions (Benjamin et al., 2014). 
Another approach is to create sampling areas from city blocks (World Bank, 2010) for example, start at the corner of a given block and approach the third shop - but using city blocks imposes a level of order that often does not exist in poor urban areas.

In this chapter I discuss the creation of two original sample frames. The first is a list of virtually all Lagos markets on local government land. The second is a businesslevel sample frame of 53,0001 Lagos shops, a sample frame that includes shops in the universe of markets in the key commercial areas in Lagos. The result is two surveys that are more representative that almost all existing surveys of informal traders. In addition, for the second of the surveys I conducted I was able to direct enumerators to specific randomly sampled shops, greatly reducing opportunities for enumerator discretion, another challenge that has plagued existing surveys of this population.

\subsubsection{Chapter 3: Case studies of markets with different institutions}

The approach I take in this chapter to assessing the argument involves conducting case studies of three markets. One market, a wine market, is a paragon of order, and I document the conditions that sustain its sophisticated private ordering institutions. The other two markets are disorderly. One market, a general market, is governed by a weak association that has not been able to push back against government threats. The other market, a car spare parts market, is an example of the rarely documented but empirically common case where group leaders extort from their own members.

The cases illuminate the mechanisms driving the relationship between market association strength, local government interventionism, contractual-trade promoting institutions, and extortion. They also provide evidence of the idiosyncratic determinants of market political power and local government interventionism in an attempt 
to assuage concerns about endogeneity and further ensure that there are no omitted variables driving the relationships observed in the survey data.

\subsubsection{Chapter 4: Testing the theory with hundreds of Lagos market associations}

In this chapter I test the argument by analyzing original data from surveys of 1,878 market traders across 269 market associations, 68 market association officials, and 55 of the 57 local government revenue collectors in Lagos. I operationalize variables to assess the main argument along with existing explanations.

\subsubsection{Chapter 5: Testing the Theory with the Market Men and Women Association}

In this chapter I broaden the scope of observation by examining how the argument works at the state level, between the the Market Men and Women Association (MMWA), an umbrella group for the markets, and the Lagos state government. The MMWA invests in institutions to protect property rights of group members, including tools to reduce "agent predation" (Markus 2015), predation by low-level bureaucrats. I present evidence that the presence of pro-trade institutions in the MMWA can be explained by my argument. While a casual observer may argue the MMWA colludes with the Lagos state government, I conclude by presenting evidence that this is not the case.

\subsubsection{Chapter 6: Conclusion}

In the final chapter I consider the bounds of the argument, and other cases the argument may extend to. I then compare the policy implications of my argument in contrast to the policy implications of a world view where private order emerges when it is needed. Last, I explore the relationship between private order in groups 
and more generalized economic growth in developing countries. 


\section{CONCEPTUALIZING MARKET ASSOCIATIONS FOR EMPIRICAL ANALYSIS AND SITUATING THE CASE}

In this chapter I do three things. First I introduce the unit of analysis, the market association, and explain how I identified these associations. Determining which traders belonged to the same association was not straightforward, and I discuss the brute force method I developed to address this challenge. Second, I provide brief background on markets and local governments in Lagos. The argument was developed in part inductively, and I provide evidence from elite interviews that helped me to understand the role of mutual threats in this context. Through this discussion I describe an exogenous source of local government interventionism that is particular to Lagos, assuaging concerns that market association strength shapes the character of the local government. Third, I discuss how I developed the sample frame and the sampling strategy used for the surveys. The two surveys involved the creation of more complete sampling frames - both at the market and trader level - than almost any other study of informal businesses in the developing world.

\subsection{What is a market association?}

The unit of analysis for this study is the market association, the group of individuals who govern a market. For some of the "traditional" markets in Lagos, markets in a physically delimited plot of land where traders sell fruits and vegetables on wooden 
stands, it is obvious what the market and market association is. The physically delimited plot of land demarcates the market, and there will be one main association for the area. This association will typically have the same name as the market. For example, if the market is called Pelewura, the association will be called the Pelewura market association, or traders might reference the Pelewura market executives. But it is not always this straightforward.

For traders in plazas - multi-story buildings with 10-50 traders in small shops one cannot assume that the association for that building is the traders' main market association. For example, figure 2.1 shows Trade Fair, a large commercial area in Lagos. Each gray rectangle is a plaza. While there are typically associations for each plaza, there are also often associations for clusters of plazas. There are further three main associations in Trade Fair: the Balogun Business Association, the Association of Progressive Traders, and the Auto Spare Parts and Machinery Dealers Association. And then there is an association for all of Trade Fair.

To determine which association was a trader's main business association, I had the following open-ended question asked in the second survey: ${ }^{1}$

What is the main market or plaza association that you belong to?

This question raised a number of challenges. Sometimes traders said they did not belong to any association, but this was rarely actually the case. Enumerators were trained at the start of the survey, and also re-trained periodically during survey implementation, about how to follow-up on this response. To determine whether the trader did in fact belong to an association, the enumerator asked traders whether they paid dues to any association, who they paid trash fees to, and whether they attended

\footnotetext{
${ }^{1}$ The first survey focused on "traditional" markets, where the main association is the association for the physically delimited plot of land, so this question was not necessary.
} 


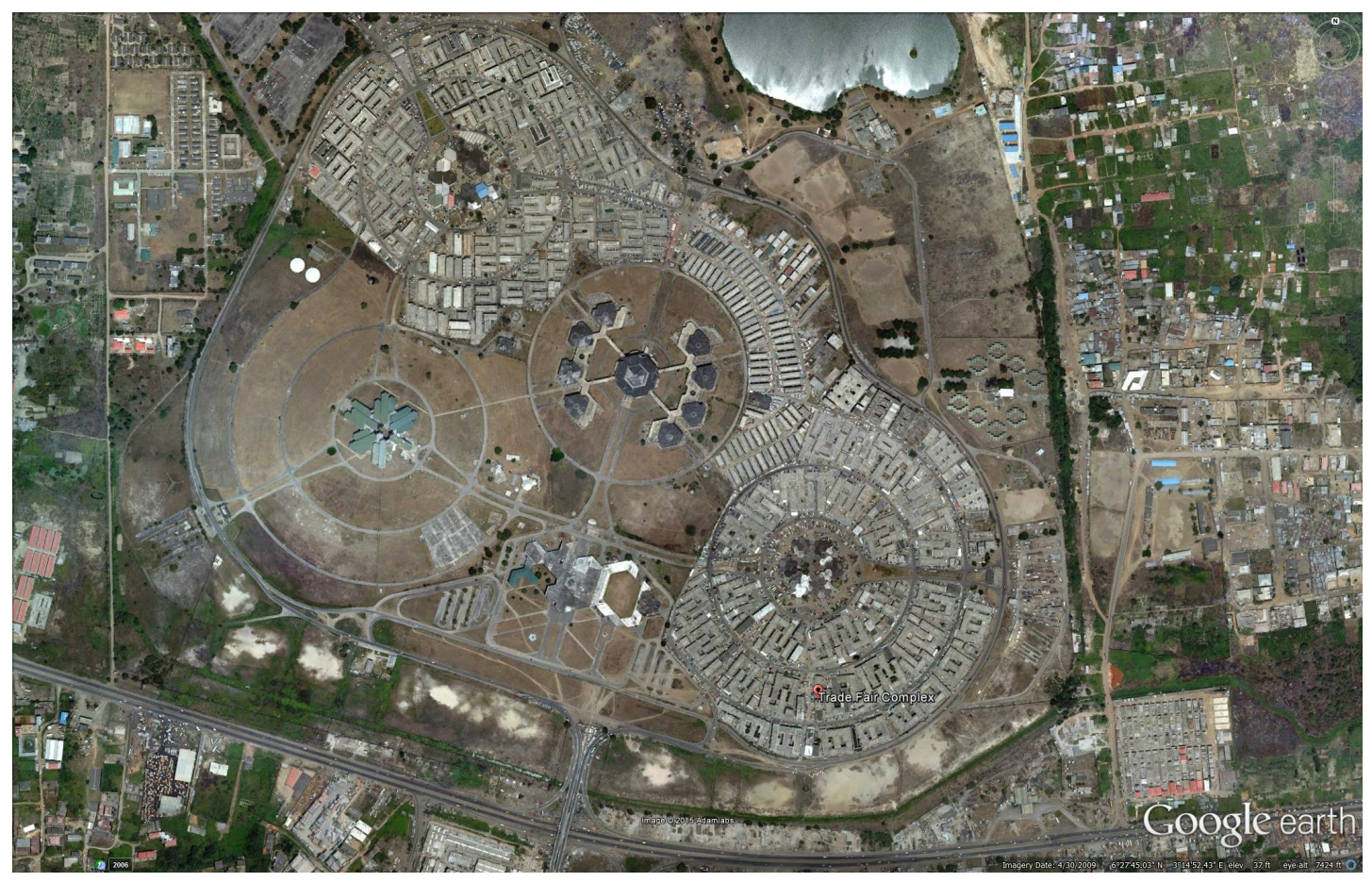

Figure 2.1: A satellite image of Trade Fair, a commercial area in Lagos. Each grey rectangle is a plaza, but the plaza association is not always a trader's main business association.

any meetings. Typically traders did, in fact, belong to an association, but said no at first because they did not have frequent interactions with the association. But it was important to consider these cases as association membership as well. If I missed these cases, the data would be censored to associations that are not very active, and this is precisely the important counterfactual that many studies of private groups miss. In some rare cases traders reported not paying dues or fees to any association and not attending any meeting. We coded this as not belonging to an association. But in most cases, the "no association" response could be overcome with a few follow up questions.

The next challenge was to determine which traders belonged to the same market association so that I could average responses by market association. As shown in 
Table 2.1: Examples of challenges in identifying which traders belonged to the same market association. If one trader reported belonging to the Balogun Market Association in Lagos Island, and another reported belonging to the Balogun Trade Association in Lagos Island, research assistants would go back to the traders and ask if these were the same association.

$\begin{array}{llll}\text { Trader ID } & \text { Market name } & \text { Area } & \text { Association ID } \\ 1 & \text { Balogun Business Association } & \text { Trade Fair } & 1 \\ 2 & \text { Balogun Market Association } & \text { Lagos Island } & 2 \\ 3 & \text { Balogun Trade Association } & \text { Lagos Island } & 2 \\ 4 & \text { BTA } & \text { Lagos Island } & 2 \\ 5 & \text { BBA } & \text { Trade Fair } & 1 \\ 6 & \text { Balogun Trader Union/ } & \text { Lagos Island } & \text { Not usable } \\ 7 & \text { Destiny Plaza Association } & & \\ 8 & \text { BBA Association in plaza } & \text { Trade Fair } & 3\end{array}$

table 2.1, this was not always simple.

Let's say trader 1 says her main market association is the Balogun Business Association, and the trader is in Trade Fair. I assign an association ID of 1. Let's say trader 2 belongs to the Balogun Market Association, and the trader is in Lagos Island. Lagos Island is a different part of the city, so despite the similarities in names this would be a different association, so I assign a new association ID. Then trader 3 reports belonging to the Balogun Trade Association in Lagos Island. Project staff were sent back to trader 3 to ask if the Balogun Trade Association was the same as the Balogun Market Association in Lagos Island. They were, so this trader also gets 2 as the association ID. Several traders, such as traders 4 and 5, provided acronyms, which were usually straightforward to figure out. Sometimes traders gave two associations, such as trader 6 who reported belonging to the Balogun Trader Union and Destiny Plaza Association. I was not able to assign an association ID here, as subsequent questions in the survey pre-filled with the response to this question. For example, a subsequent question asked "Does [association name pre-filled] have an elected leader?" It would not be clear how to interpret a response to this question 
Table 2.2: Sample sizes for both surveys.

\begin{tabular}{|c|c|c|c|c|}
\hline & $\begin{array}{l}\text { Traders } \\
\text { surveyed }\end{array}$ & $\begin{array}{l}\text { Associations } \\
\text { represented }\end{array}$ & $\begin{array}{l}\text { Market leaders } \\
\text { surveyed }\end{array}$ & $\begin{array}{l}\text { Local government } \\
\text { revenue collectors }\end{array}$ \\
\hline 2013 survey & 699 & 68 & 68 & 55 \\
\hline 2015 survey & 1,179 & 203 & $\mathrm{O}$ & $\mathrm{O}$ \\
\hline Total & 1,878 & $\begin{array}{l}269 \text { ( } 2 \text { associations } \\
\text { were captured } \\
\text { in both surveys) }\end{array}$ & 68 & 55 \\
\hline
\end{tabular}

if two association names were pre-filled here. Enumerators were re-trained to only write down the respondent's main association. Occasionally traders reported belonging to a plaza-level chapter of a larger association, as trader 8 did. In these cases, project staff were sent back to the trader to ask if the leadership for this chapter was the same as the broader association. If they were, I assigned the same association ID as the broader association. If they were not, I assigned a unique association ID.

It is worth making brief note of a special type of association called commodity unions. Commodity unions are associations for traders selling particular products. Within a traditional market there might be a tomato commodity union, for example. Commodity unions typically scale up, paralleling Nigeria's levels of government. The tomato commodity union for a market would be part of the tomato commodity union for the local government, which would be part of the tomato commodity union for the state government, which would be part of the Nigerian tomato commodity union. Different commodity unions have different levels of activity; for many commodities some of these entities may not be particularly active. The main purpose of commodity unions is price fixing, but the effectiveness of the price fixing is highly variable. Because commodity unions in Lagos tend to not do much beyond price fixing, these associations are not the focus of this project. 


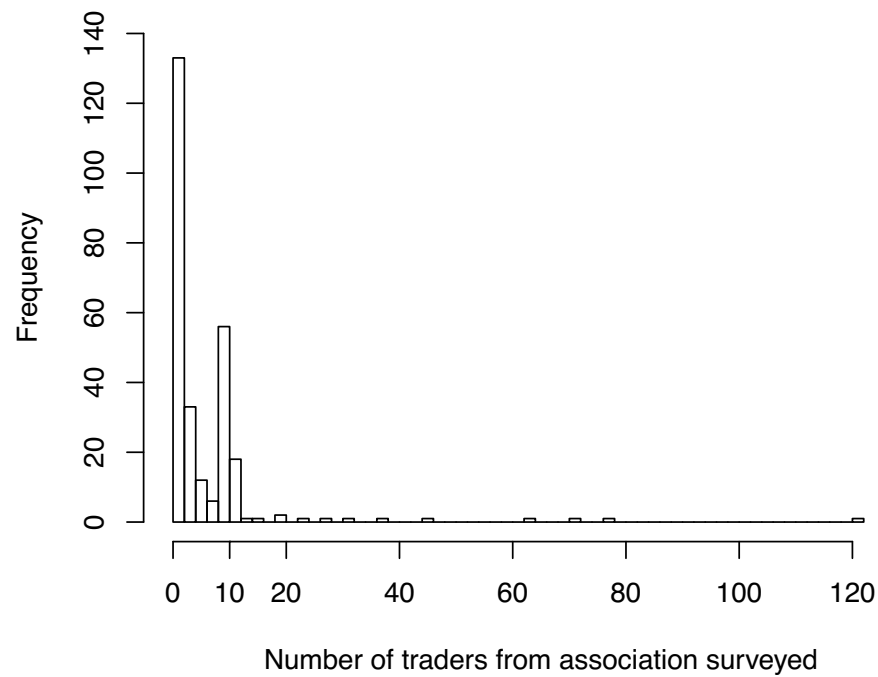

Figure 2.2: I have interviews with 1-11 traders for most market associations. This figure shows a histogram for the number of traders surveyed in each association represented in the sample (including the 2013 and 2015 surveys). There is a spike at 10 and 11 because in the 2013 survey 10-11 traders were explicitly sampled in each of the 68 market associations. In the 2015 survey, 121 of the traders surveyed belonged to the Balogun Traders Association on Lagos Island.

\subsection{Situating the case}

In this section I first introduce the context in which I assess the argument, markets in Lagos. I then describe how the mutual threat argument works in Lagos, describing the types of threats a market can make against a local government, and vice versa. Last I explain how these threats incentivize market associations to maintain pro-trade institutions inside their markets. 


\subsubsection{Markets and politics in Lagos}

I test the argument in Lagos, the commercial capital of Nigeria. Lagos has between 15 and 21 million residents, ${ }^{2}$ tens of thousands of traders, and dozens of local governments.

Lagos markets typically have a few hundred shops, selling products ranging from mobile phones to baby clothes to kitchenware. Most markets are located on land that is either privately held or owned by the local government. Some markets are headed by elected leaders who have term limits, and others are headed by leaders who hold their position for life, an institution that has existed in a subset of Lagos markets for over a century. Other markets are headed by the owners of the land the market is on, and these are similarly positions without term limits. Market associations collect fees from traders that are used for trash collection, security, and fuel for generators. They serve as the liaison between traders and government officials.

Nigeria has a federal system of government, with 36 states and over 800 local governments with (typically) democratically elected chairmen. One party, the All Progressives Congress party (APC), dominates all branches and levels of government in Lagos state. ${ }^{3}$ By far the most relevant level of government for markets is the local government, as it is constitutionally mandated to maintain and regulate markets and permitted to collect taxes from market traders. Power within a local government is concentrated in the chairman, who is directly elected by local government citizens and appoints the heads of departments within the local government (Barkan, Gboyega

\footnotetext{
2 The exact population size is unknown as the national census is politicized. States with more people should in theory receive more money from the federal government, but because Lagos has historically been controlled by an opposition party the federal government has had an incentive to underreport the true population.

3 Until local elections were postponed and caretakers were appointed to head local governments at the end of 2014, APC chairmen headed all of Lagos' 57 local governments.
} 
and Stevens, 2001).

Market associations are critical for promoting trade as courts in Lagos cannot be relied on to enforce contracts nor to enforce laws that protect property rights. Over the past 15 years Lagos state has implemented governance reforms that have increased protection of property rights, but these reforms are incomplete and unevenly enforced. For example, the average number of days to resolve a standard commercial dispute in a Lagos court has dropped to 447 days - below even the average for Cape Town, South Africa - but the average cost of resolution is $62 \%$ of the claim value, compared to $34 \%$ in Cape Town (World Bank, 2014). Independent state audits of local government accounts have been introduced to increase local accountability, but these reports still regularly reveal huge sums of unaccounted money (Office of State Auditor General, 2012). In 2011 a law was passed prohibiting street hawkers, a priority for many market traders who lose business to them, but as of 2016 enforcement has waned and street hawkers are visible throughout the city. In short, despite some public institutional improvements, Lagos still falls within the scope condition of the theory as a city where the rule of law is weak.

\subsubsection{How strong market associations can sanction local governments}

If a strong market association can mobilize traders, it can threaten politicians. Traders can be mobilized to perform highly visible acts of protest. Actions such as shutting down the market for the day and leading a protest to the state government get the attention of the state party, which has few other reliable ways of getting information about public (dis)satisfaction with the local government. Protests by traders have resulted in local chairmen losing their position in government. According to Bola Tinubu, a wealthy former Lagos state governor who is the de facto leader of the 


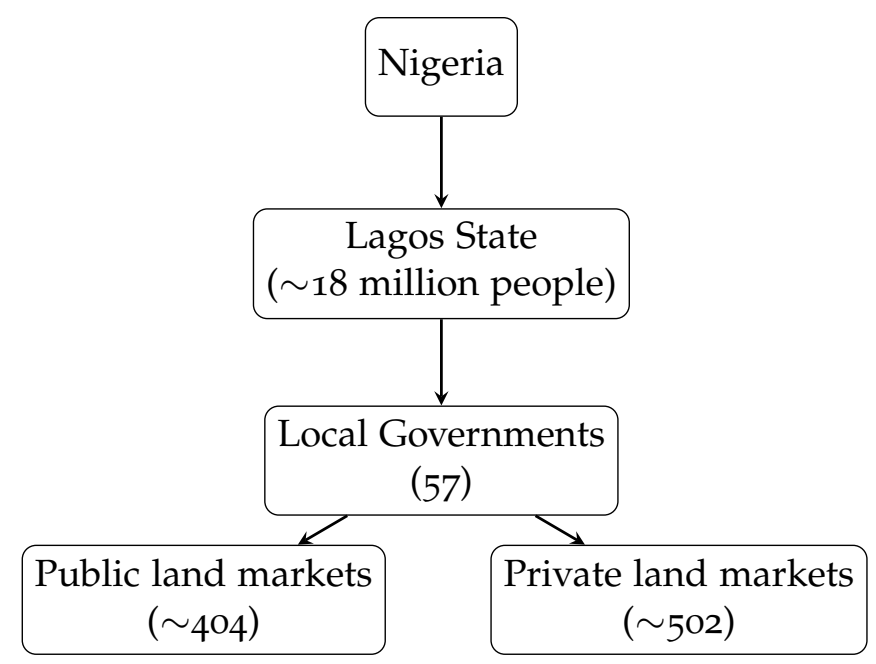

Figure 2.3: Lagos state, which encompasses the city of Lagos, is the commercial center of Nigeria. Lagos state has hundreds of markets throughout its 57 local governments.

APC:

[T]raders act as reliable sources of information for the government and political parties...[and] serve as the crucial feedback mechanism needed by the government and policy makers to evaluate instituted and proposed policies. ${ }^{4}$

In the Nigerian context, where the party that controls the state government typically controls all local governments in the state, the most critical hurdle for aspiring local government chairmen is getting the party's nomination, not the actual elections. Thus a clear protest action would hurt a chairman seeking renomination. According to the Lagos APC chairman Henry Ajomale:

Traders can prevent a chairman from getting renominated. We take cognizance of that. If we reappoint such a person we will run into trouble. In Alimosho [one Lagos local government] we picked someone, people protested, so we gave the

\footnotetext{
4 Interview via email, Feb. 5, 2014
} 
nomination to someone else. This was before the election. We have done this so many times. ${ }^{5}$

When asked what constrained a local government from renovating a market which would price out existing traders - one local government chairman told me he "negotiates with traders because they are voters. And some of them are party members; you don't want public outcry." ${ }^{\prime 6}$ It is not always the case that market traders could prevent an APC-nominated candidate from getting elected with their electoral power alone. But the APC wants organized societal groups to support their leadership, and protest is embarrassing for the APC and weakens the party's credibility.

\subsubsection{How local governments can sanction markets}

Two factors shape whether local governments can credibly threaten markets: whether the local government chairman is politically ambitious, and whether the market is on public land. To understand the contextual conditions that make the emergence of an ambitious chairman more likely, I first describe the role of traditional ruling families in Lagos. I then discuss why local governments are more of a threat to markets on public land.

Political norms in Lagos are such that traditional ruling families have an outsized claim to head local governments in which their homes (physical palaces) are based. While the formal rules are constant across local governments - ward delegates vote for the nominee - this process is highly vulnerable to the influence of a man who is

\footnotetext{
5 Interview, Jan. 20, 2014. It is not the case, however, that traders can influence the type of local government chairman who gets elected (e.g. the interventionism of the chairman). For example, if a market prevents a non-interventionist candidate from a traditional family from being nominated, a different non-interventionist candidate from the traditional family will be nominated.

${ }^{6}$ Interview, Jan. 12, 2013
} 
locally termed the godfather, Bola Tinubu, the patron of politicians in the region. In local governments with traditional ruling families, the godfather ensures the chairman will come from one of these families. When there is more than one family, typically a zoning system predominates, with the families alternating in nominating one of their own each three-year term. Roughly half of the chairmen who come from traditional ruling families tend to be older, less politically ambitious, and plan to retire to their communities when leaving office. These chairmen lack incentives to make credible threats against markets and market leaders. The other half are younger and more ambitious.

In local governments with no traditional ruling families, the nomination process is competitive. Almost without exception, the winners hope ultimately to work for the state government or to become a representative in the state House of Assembly or even the National Assembly.7 Their ability to obtain higher office depends almost entirely on whether they will receive support from the godfather. The godfather evaluates chairmen principally on three criteria, which are sometimes contradictory in practice: the extent to which they maintain public support throughout their tenure, how much revenue they are able to raise through taxes, and the extent to which they modernize their local government in line with "Megacity" ideals (de Gramont, 2014). Chairmen who come to office through this competitive process aim to excel on all fronts. Market leaders will rarely view efforts to increase taxes on traders as anything but a threat, and modernizing goals often translates as market renovation, which can price out current market leaders and traders. Interventionist chairmen not only have incentives to make these threats, their threats are credible as they are backstopped by the constitution. The constitution allows local governments to tax and "maintain" the

\footnotetext{
7 This claim is based on interviews with officials from ten local governments and the Ministry of Local Government and Chieftancy Affairs.
} 
markets.

Local governments can pose a greater threat to markets on public land than markets on private land because they have more rights to intervene in public markets. It would be difficult for a local government chairman to threaten to demolish a market that is on land owned by a private individual, but they do have the right to demolish (and rebuild) a market on public land. While local governments are limited to a prescribed number of fees they can collect from traders on both types of markets, they collect rent from traders in public markets; intimations of raising rent are serious threats. $^{8}$

Interventionist local governments can also credibly threaten non-compliant markets - such as markets that refuse to comply with tax increases - with lawsuits. Lawsuits are costly for both parties, with only strong market associations potentially able to mobilize traders to raise funds internally that would finance legal fees. Weak market associations will accede to demands interventionist local governments make, knowing they cannot raise the necessary funds. While in theory bargaining between the local government and the market should be possible without a lawsuit, in the Lagos context both the local government and the group have imperfect information about the abilities of the other.

\subsection{Survey details}

\subsubsection{Survey sampling}

I conducted two surveys for this project. The first survey targeted mostly public markets and was administered between August and October 2013. 699 traders, 68

\footnotetext{
${ }^{8}$ See Frye and Yakovlev (2016) for another strategy to identifying exogenous variation in state-firm bargaining power.
} 
market leaders, and 55 local government revenue collectors were interviewed. The second survey, which targeted mostly private markets, was administered to 1,179 traders between April and June 2015. ${ }^{9}$

The ideal sample frame for this project would include all small businesses in Lagos state. As most small businesses are located in physical markets (as opposed to being an isolated shop in a residential area), we started with a list of markets from the Lagos Waste Management Authority (LAWMA). LAWMA collects trash from markets, and because their efforts are subsidized by the state government even poorer markets are included on their lists. LAWMA had two lists: one for open-air markets on public land, and the other for plazas, multi-story buildings with many shops that are typically on private land. The former list had 452 markets and the latter had 502 markets.

The starting points for the sample frames were two lists of markets, public and private land markets, from the state trash agency. The public market list, with 452 markets, was cross-checked by having enumerators ask each local government revenue collector for a list of markets under their control. I sampled the public markets using a stratified random sampling strategy, stratifying on market association strength and local government interventionism. ${ }^{10}$

While these lists seemed fairly complete, they were missing markets in a few key commercial areas (possibly because these areas had their own lists that we did not obtain), and some places that were called markets were in essence large commercial areas. We hired a research assistant to map out both the missing areas along with the

\footnotetext{
9 The second survey was conducted in collaboration with Meredith Startz.

${ }^{10}$ For sampling purposes, these variables were measured using data from the local government revenue collector survey.
} 


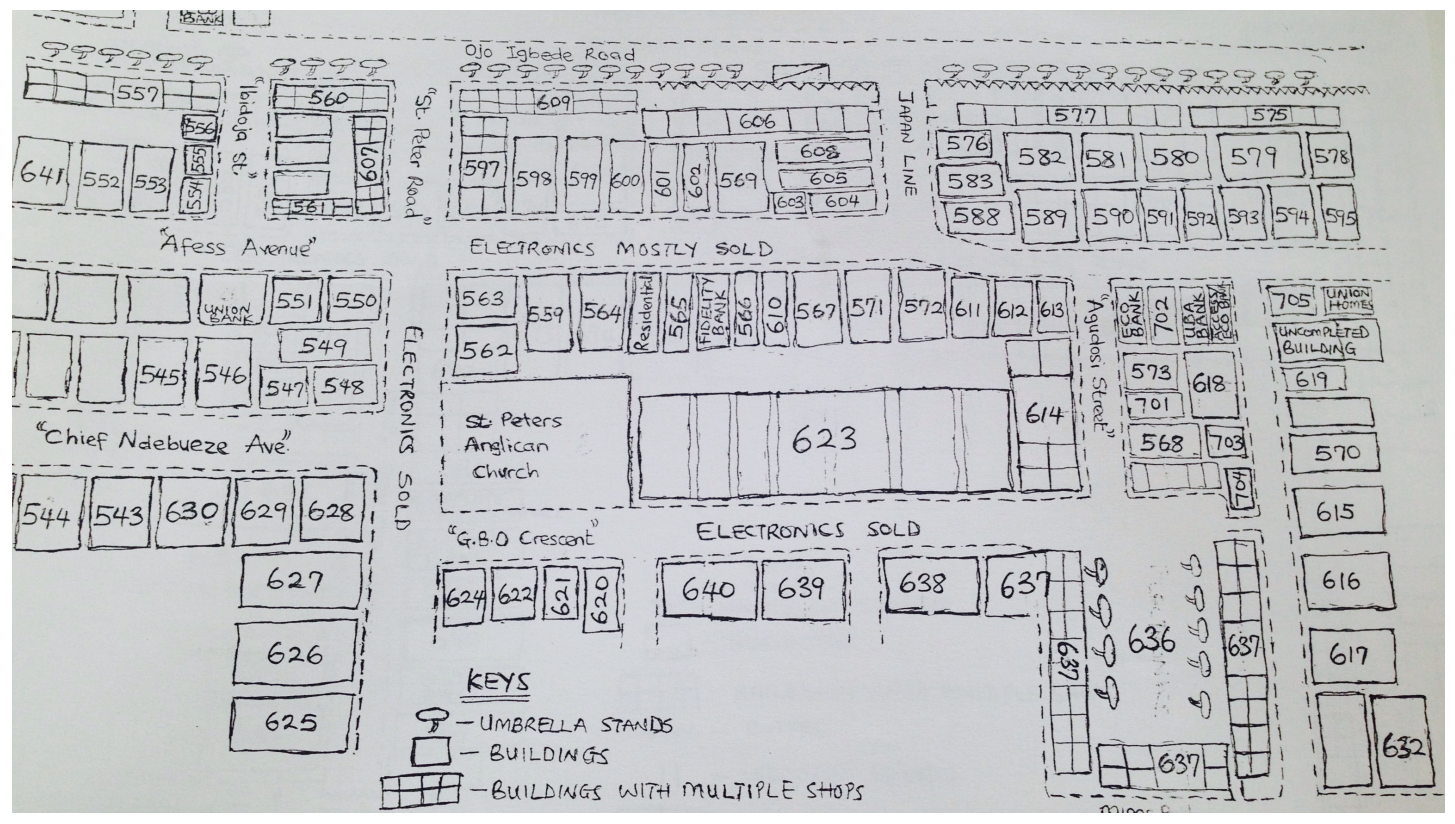

Figure 2.4: A map of one section of Alaba International Market created for sampling purposes. Aluko Abubakar Olanrewaju, a research assistant, drew this map. He and other research assistants counted the shops in each part of the market. Enumerators were then instructed (for example) to go to building 616 in Alaba International Market, walk up to the second floor, turn right, and find the third mobile phone shop.

areas that were called markets but were in fact much larger than a typical market. ${ }^{11}$

Market associations keep accurate lists of traders in their markets, but these lists are among the most valuable and sensitive information market leaders possess. Market leaders want to understate the true number of traders to tax collectors, and prevent government officials from enumerating the market. Thus developing sampling frames for traders within markets was difficult. For the public markets, I developed a random walk strategy for enumerators to follow.

\footnotetext{
${ }^{11}$ The areas we had mapped included: Alaba (pictured in figure 2.4), Dosunmo, Oke Arin, Paul and Mike, and Trade Fair. We also had Katangua (sometimes called Super Traders) Market (a used-clothing market) and Ladipo Spare Parts Market mapped, but these markets were not included in the sample frame for the survey.
} 
Table 2.3: The shop count resulted in a dataset with information on the number of shops on each floor in each plaza, along with information on the types of product being sold. The data below are not real, and many other product categories are included in the real data.

\begin{tabular}{|c|c|c|c|c|c|}
\hline Plaza name & Address & Floor \# & $\begin{array}{l}\text { \# shops } \\
\text { selling } \\
\text { textiles }\end{array}$ & $\begin{array}{l}\text { \# shops } \\
\text { selling } \\
\text { jewelry }\end{array}$ & $\begin{array}{l}\text { \# shops } \\
\text { providing } \\
\text { services }\end{array}$ \\
\hline Goodluck Plaza & $\begin{array}{l}132 \text { Adewale St., } \\
\text { Lagos Island }\end{array}$ & $\mathrm{O}$ & 5 & 9 & $\mathrm{O}$ \\
\hline Goodluck Plaza & $\begin{array}{l}132 \text { Adewale St., } \\
\text { Lagos Island }\end{array}$ & 1 & $\mathrm{O}$ & $\mathrm{O}$ & 5 \\
\hline
\end{tabular}

For the private markets, research assistants were hired to count the number and type of shops in every market, resulting in a listing of 53,001 shops. This shop count resulted in a more complete sample frame than that used for almost any other survey of informal firms. The structure of the listing data is shown in table 2.3.

\subsubsection{Sampling}

From this listing we then removed the 18,249 shops that were vacant, closed during business hours, or provided services (such as a hair salon), and then randomly sampled from the remaining 34,752 shops. For example, we might randomly sample textile shop number 3 on the second floor of a given plaza. There is no meaning here to "number 3," but we wanted to reduce enumerator discretion as much as possible. A tracking sheet would then direct an enumerator to go to the second floor of a given plaza and approach the third textile shop. These instructions were imprecise; two enumerators could follow the instructions precisely and end up at different shops if they arrived at the floor on different entrances. But the goal was for the enumerators to think that we had actually pre-selected a certain shop. When enumerators asked us about the multiple entrance issue, we advised that they use the main entrance. 
Ultimately, however, we were indifferent to which entrance they used, so long as they thought we had a pre-selected shop.

To audit on the sampling strategy, for 10\% of the surveys we had auditors assess whether the interviewed trader could have been selected by following the sampling strategy. Could this shop have possibly been the third textile shop from one of the entrances? This was not always straightforward, because sometimes certain shops are closed, and when shops are closed you cannot see inside to determine what they are selling. So an enumerator might identify what she perceives to be the third textile shop, while the auditor counts it as the fifth if more shops were open when the auditor visited. We asked auditors to be somewhat generous here. But if the shop did not sell textiles, for example, that indicated an issue in following the sampling protocol. $^{12}$

\subsubsection{Incentives}

Lagos traders tend to be very busy, and because the modal shop has no employees, traders typically cannot leave their shop during business hours. To incentivize traders to take the time to participate in the interview while simultaneously manag-

\footnotetext{
12 In addition to the audits, we ran high frequency checks on the data while the survey was being fielded. Some examples of checks we ran included: 1) Looking at responses to a single open-ended question by enumerator. If an enumerator was writing similar answers for all respondents we would follow up with the enumerator. 2) Red flagging any enumerator who was entering unrealistically high numbers for questions about fees, such as how much the trader pays for trash collection. Unrealistically high numbers often indicated that the enumerator entered in one too many zeros. The project manager would then meet with the enumerator to emphasize the importance of attention to detail. 3) Red flagging any enumerator who had multiple "no association" responses to the question about the trader's main market association (described in more detail in section 2.1). Because a response of no association meant that the following two sections of the survey could not be completed, it was critical that enumerators followed up with traders to ascertain if they really did not belong to any association. The project manager would meet with enumerators who repeatedly entered "no association" to discuss the importance of this question.
} 


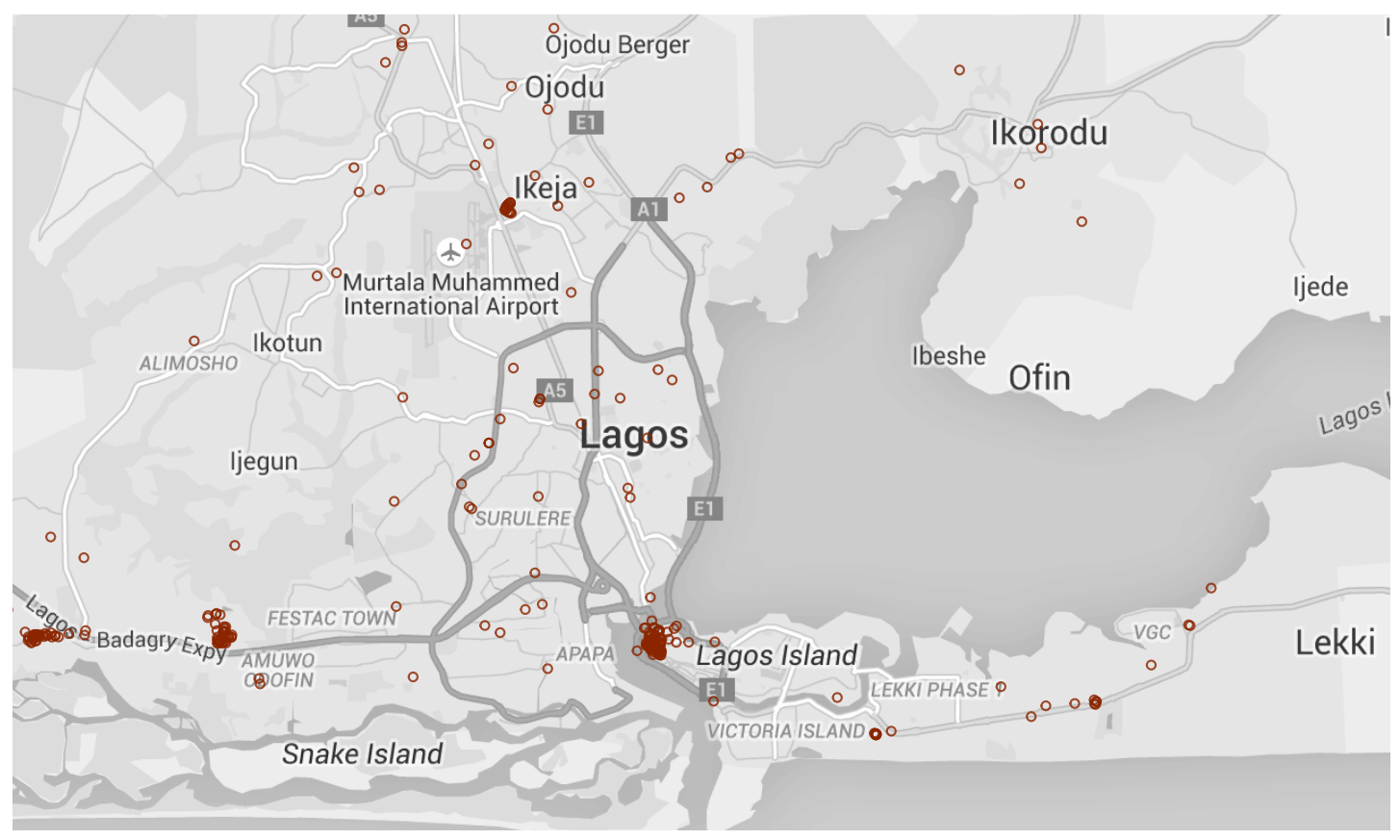

Figure 2.5: Market associations represented in the 2013 and 2015 surveys. The clusters of dots are dense commercial areas.

ing their shop, for both the 2013 and 2015 surveys we provided 400 Naira $(\$ 1.66)^{13}$ in phone credit to the respondent at the end of the survey. For the 2015 survey, we employed two additional strategies. First, at the start of the interview enumerators gave traders a folder branded with the name of the survey (the Lagos Trader Survey), along with a Travel Information Pamphlet with information on business etiquette in countries that Lagos traders travel to, like China and the UAE. Second, enumerators provided respondents with a sheet of paper with WhatsApp numbers and BlackBerry Messenger pins for myself, my collaborator Meredith Startz, and the project manager. Enumerators encouraged traders to reach out to us. The three of us have chatted in-

\footnotetext{
${ }^{13}$ In the course of research for this dissertation, the exchange rate has fluctuated greatly, ranging from N152 to the dollar in July 2011 to a high of N330 to the dollar in December 2015. In this dissertation, I will use an exchange rate of N241 to the dollar. This is the average of the two.
} 
formally with 93 traders who reached out to us over these platforms, often to verify the legitimacy of the enumerators.

\subsubsection{Market leader survey}

For the 2013 survey of market leaders, in each of the 68 sample markets enumerators were instructed to interview either a market mother, market father, secretary, chairman, vice chairman, treasurer, or public relations officer. It was not feasible for the market mother, for example, to be interviewed in all markets, as market leaders are difficult to convince to be interviewed. Even given the broad set of seven eligible leaders, 19 of the 68 interviews required two or more attempts to get an interview with any leader.

\subsubsection{Local government revenue collector survey}

In 2013 enumerators surveyed local government market masters, a title I will not use in this project to avoid confusion with private market leaders. The local government market master is one type of revenue collector, responsible for collecting fees and rent from markets on local government land. The survey asked them questions about every market in their jurisdiction, along with questions about attributes of the local government chairman. Enumerators were able to achieve interviews with market masters in 55 of the 57 Lagos local governments. Unfortunately, at the end of the survey I learned that a small number of local governments had so many markets that they had two market masters. Because I only had one market master interviewed in these local governments, my public land market sample frame is censored to the markets under the second market master. 


\subsection{Conclusion}

In this chapter I discussed the strategy used to carefully determine which traders belonged to the same association. Background information on local governments and markets in Lagos was provided. Last, I discussed the exhaustive efforts to create accurate market and business-level sample frames. 


\section{CASE STUDIES OF MARKETS WITH DIFFERENT INSTITUTIONS}

In this chapter I test the theory with three markets in Lagos. The first market, OkeArin, is an archetype of order, with sophisticated pro-trade institutions managed by the market association. I assess the extent to which the conditions that sustain these institutions are consistent with my theory.

The second and third markets, Ladipo Main Market and Dabiri, ${ }^{1}$ are cases of failing markets. Existing research on private order assumes that failing groups disappear quickly, as current group members abandon them and prospective group members decide not to join. I document that failing groups can hold on for much longer than has been assumed.

The case of Ladipo highlights in particular the persistence of a special type of failing group: one where the group leader extorts from its own members. Ladipo is governed by a predatory association that extorts from its own members and betrays traders to pursue their own private interests. Existing work assumes that group members are mobile and would move into a better group if a group leader extorted. Group leaders, knowing this, would choose not to extort for fear of losing members. But this cannot be assumed. This section documents that predatory associations exist. Additionally, research on private order often implies that a strong association and, relatedly, the ability to create and enforce formal private governance rules, are sufficient

\footnotetext{
${ }^{1}$ I have changed the name of this market to protect the identity of respondents who shared sensitive information. I have not changed the names of Oke-Arin and Ladipo.
} 
for order. Yet the Ladipo Main Market, with an exceptionally strong association and a 72 page constitution with provisions that are strictly enforced, is a paragon of disorder. Ladipo Main Market provides an account of the perils of having a strong association that is not motivated to use its power to promote trade. This phenomenon has been widely documented in research on public governance - we know that strong, authoritarian governments both exist and can have pernicious effects of citizen welfare - but these are cases that have largely been ignored in research on private governance.

Dabiri is a different type of failing market. It is an example of a market governed by a weak association located in a jurisdiction governed by a highly aggressive local government. The association is well-intentioned but has not been able to push back against a government that wants to destroy the market.

Despite being inhospitable to trade, these markets persist. Why is this? I conclude by showing that the obstacles to leaving a group are many, and that imperfect information about group conditions makes it hard to avoid failing groups.

In what follows I use within-case analysis methods, such as process tracing, to make inferences about whether the conditions that enable or impede market association good governance are consistent with the theory (Brady and Collier, 2010; Goertz and Mahoney, 2012). One challenge is that the argument is about conditions that sustain private order. I do not expect to see dramatic changes in either market association strength or local government interventionism. Thus I do not expect to be able to present evidence of sequencing consistent with a causal argument, which is often one of the strengths of this method (Collier, 2011).

Through these case studies, I will take on two additional tasks. First, I will assess the validity of additional factors that may explain the outcome, and try to inductively gain intuition about why or why not these explanations are valid. Similarly, one of the 
cases involves collusion, and I will use this case to inductively derive factors that may support collusion. Second, I will gain a deeper understanding of the determinants of market association strength and local government interventionism and discuss the validity of concerns that these two variables are endogenous to each other.

Oke Arin and Dabiri markets were selected by randomly selecting markets from the survey data on the explanatory variables. I subsetted the survey data to markets with strong and weak associations in interventionist local governments and randomly selected markets from each of these categories. In the first market in each category, I was not able to get traders or market executives to speak with me openly. I randomly selected new markets in each of these categories, and those markets were Oke Arin and Dabiri. I originally tried to speak with traders in markets that had strong associations but were in non-interventionist local governments, but after several attempts was not able to succeed. Ultimately, I decided that because one contribution of this project was to document that predatory associations exist, I would simply try to find any market governed by a predatory association where I could get traders and market leaders to speak with me. Ladipo was this market.

\subsection{An orderly market}

\begin{tabular}{c|l|l|}
\multicolumn{1}{c|}{} & \multicolumn{1}{l}{ Interventionist government } & Non-interventionist government \\
\cline { 2 - 3 } Strong assoc. & $\begin{array}{l}\text { Market: Oke-Arin Market } \\
\text { Argument predicts: Order } \\
\text { Observed: Order }\end{array}$ & \\
\cline { 2 - 3 } Weak assoc. & & \\
\cline { 2 - 3 } & &
\end{tabular}

In this section I will discuss Oke-Arin, a market with many pro-trade institutions. 
The theory expects that pro-trade institutions will be sustained when a strong association is faced with external threats from the state. Consistent with the theory, evidence from Oke-Arin shows that the association 1) implements pro-trade institutions to limit state interference - in this case interference from the National Agency for Food and Drug Administration and Control, and 2) does not extort from traders so as to be able to mobilize them to fend off state threats, here threats from extractive local politicians.

\subsubsection{Order in Oke-Arin}

Oke-Arin is a market with private institutions that unequivocally promote trade. The market association shares information about individuals to avoid doing business with: in monthly market meetings the association will warn traders about dubious suppliers and companies. The association will punish wholesalers based outside the market who sell substandard products to traders inside the market, in some cases apprehending these individuals, and banning them from doing business in the market. There is aggressive in-group policing in Oke-Arin, with the market association punishing traders who break rules or sell sub-standard products to maintain the reputation of the market as a place where customers can feel confident in the quality of products they buy. The association confiscates sub-standard products traders are selling, and if the trader had been knowingly buying from a supplier who was banned from the market, the market association might lock the shop to prevent trading. Further, there is no private extortion in this market: in the survey data only one of the eight Oke-Arin traders interviewed reported that the market association does not account properly for the fees it collects. And the market association works aggressively to limit public extortion, including by filing a lawsuit challenging a proposed tax in- 
crease by the local government. In short, Oke-Arin is a paragon of private order. What explains this? Much of the evidence from Oke-Arin is broadly consistent with the theory of external government threats motivating the private provision of order.

\subsubsection{What is Oke-Arin?}

Oke-Arin is a market spread throughout a series of narrow and crowded streets on Lagos Island. Traders sell wine, mostly, but also meat, baking items and provisions. Interviews strongly confirmed what the survey data suggested: Oke-Arin has a strong market association and is in a district governed by an interventionist government.

Oke-Arin occupies the western corner of Lagos Island which has been registered as a market area for decades. In 2004 many Igbo traders on the Island pooled funds to lease land for a new and larger market on the outskirts of the city. As thousands of traders set up shops in this new market, existing organizations on Lagos Island were dismantled. The Oke-Arin market association emerged from what had previously been a larger market association called the Balogun Business Association.

\subsubsection{In-group policing and information sharing to keep the government out of market

$$
\text { affairs }
$$

Consistent with the argument, pro-trade institutions in Oke-Arin are designed to protect the market from the meddling hand of the state. Because the traders in OkeArin import food and beverages, they have frequent interactions with the National Agency for Food and Drug Administration and Control, or NAFDAC, which will order traders arrested if they are selling falsely branded products. ${ }^{2}$ When NAFDAC

\footnotetext{
2 Abimbola Akosile, "NAFDAC Docks Four Over Counterfeit Products," This Day, 26 October, 2014, thisdaylive.com/articles/nafdac-docks-four-over-counterfeit-products/192266/ (accessed May 30, 2015), and Kenechukwu Ezeonyejiaku, “NAFDAC Uncovers Illegal Production Facilities, Counterfeit-
} 
officials intervene in the market they are accompanied by the Mobile Police, who come in pick-up trucks with guns pointed out the windows. This is a rent seeking opportunity and also scares customers away. To reduce the likelihood that situations will escalate to NAFDAC's attention, the market association polices the behavior of the traders. ${ }^{3}$

How does it do this? The strategy relies in part on customers. When customers purchase sub-standard products they report the trader to the market association. The market association has 30 executives, including heads of each of 10 sections. The relevant section head will be informed, and will confiscate any sub-standard products the trader is still selling. If the trader had been knowingly buying from a supplier who was banned from the market, the market association might lock the shop to prevent trading.

Information sharing about suppliers who sell substandard products is also critical for ensuring quality in the market. In many markets traders might not want to report being cheated by outside suppliers because they are in competition with other traders in the market. They might, in fact, want their neighbors to be cheated by a supplier they were cheated by. In Oke Arin, however, traders are motivated to report opportunistic behavior because the market association will help to resolve the immediate dispute. This private benefit motivates individuals to contribute to a club good, essentially a directory of individuals to be avoided. When alerted to opportunistic suppliers, the market leaders will punish them, and in some cases apprehend these individuals and ban them from doing business in the market. At the market meetings the market leaders will inform traders about dubious suppliers and companies ers," The Guardian, 23 October, 2014, allafrica.com/stories/201410231259.html (accessed May 30, 2015).

3 Interview with Oke-Arin market leader on June 16, 2015 
to avoid.

\subsubsection{Absence of private extortion allows association to mobilize traders to fend off government threats}

Oke-Arin has faced continuous threats from the local government. From the year the market formed, Lagos Island West local government has been aggressively trying to raise tax revenue from the market. The persistence of local government interference can be attributed to characteristics of the local government that are uncorrelated with market success: many traditional families have their palaces in Lagos Island West, and it is accepted that chairmen will come from one of these families. ${ }^{4}$ The traditional families in Lagos Island happen to own a large share of the land in the local government, land that has exceptionally high potential value given that the Island connects so many parts of the city.

The first local government chairman was Aderinola Disu. Disu came from the Akinsemoyin Royal Family, a family that owned substantial land. In the early 2000 s the economic interests of the traditional families in Lagos Island were under threat. Decaying infrastructure and the presence of thugs pushed many businesses out of the Island. In response the land owners formed a coalition, and Disu - a prominent member of the coalition - successfully sought the nomination of the Alliance for Democracy party, the precursor to the APC. $5^{5}$ Disu's emergence was tied to the economic problems plaguing the area during the time of her election. ${ }^{6}$

\footnotetext{
4 In general, when local government chairmen come from traditional families, they are not interventionist. In the cases presented in this chapter, all three local governments have interventionist chairmen. Two of the local governments have chairmen from traditional families. This is not typical.

5 Interview by email with Disu on June 24, 2015

${ }^{6}$ While Disu's engagement in the community during her tenure is undoubtedly tied to the business potential of the area, it does not seem to be the case that strong, successful market associations pressured
} 
Consistent with the theory, it seems likely higher public sector career ambitions partly motivated Disu's performance. Since being appointed to the boards of two state agencies "[a]s a reward for exemplary performance as the Chairman of the Lagos Island Local Government," she worked as the Special Advisor on the Central Business Districts, a high state government level position.

In 2006 Disu tried to increase taxes in Oke-Arin, but the market claimed it had received a promise from an earlier local official that its traders would never have to pay more than 5,500 Naira/year (\$22.82) in fees to local government. In 2006 the market took the local government to court. The case was not resolved until a year into the tenure of the subsequent chairman, Eshinlokun Sanni Wasiu Olatunji, ${ }^{7}$ when the judge ordered the parties to settle out of court. The market and local government agreed on 6,500 Naira/shop/year, 2,000 Naira less than what the local government had been aiming for. That Olatunji continued to pursue the case underscores the persistence of local government interventionism, while Oke-Arin's legal challenge is indicative of the market association's willingness to fight back.

When asked what threats the market could make against the local government at the time, and what threats the local government could make against the market, Disu said:

"The powers the markets had over the local government were first, in a Democratic Dispensation there is freedom of expression and exercise of fundamental human rights by seeking relief through legal channels. [...] Conversely the powers the local government had over the traders were legal and entrenched in the the ruling party to nominate a certain type of politician.

7 Consistent with the argument, Olatunji also had higher career ambitions, and in 2015 became a member of the Lagos State House of Assembly. 
1999 Constitution of The Federal Republic Of Nigeria, Schedule IV [a reference to the right to tax markets]" ${ }^{\prime 8}$

The court case with the local government is evidence of the market association's commitment to managing taxation, and in the survey no trader in Oke-Arin reported that local government officials ever show up by surprise to collect fees. As noted earlier, almost all traders report an absence of market association extortion. This makes sense - the association needs the support of traders to keep the lawsuit going.

\subsubsection{What makes association threats credible?}

For the government and association to check each other their threats must be credible. How can we be sure politicians perceive the market association as strong and its threats as credible? Representatives of both of the leading presidential contenders visited the Oke-Arin market association in 2015 to solicit their support. Gubernatorial and senatorial candidates come as well. As the argument expects, the Oke-Arin market association endorses political candidates. The association will conduct question and answer sessions with traders at the monthly meetings in front of politicians, allowing politicians to see the association's ability to bring traders around to a certain position.

As further evidence of the association's strength, the market has market-wide meetings for all traders in a church every month. All shops shut down during this meeting, a visually striking occurrence. "People see this," the market leader said. "Everyone knows we are strong." 9

\footnotetext{
${ }^{8}$ Interview by email on June 23, 2015

9 Interview with Oke-Arin market leader on April 21, 2015
} 


\subsection{A failing market governed by a predatory market association}

\begin{tabular}{c|l|l|}
\multicolumn{1}{c}{ Strong assoc. } & \multicolumn{1}{l}{ Interventionist government } & \multicolumn{1}{c}{ Non-interventionist government } \\
\cline { 2 - 3 } & $\begin{array}{l}\text { Market: Ladipo Main Market } \\
\text { Argument predicts: Order } \\
\text { Observed: Disorder }\end{array}$ & \\
\cline { 2 - 3 } Weak assoc. & & \\
\cline { 2 - 3 } & &
\end{tabular}

In this section I will discuss Ladipo Main Market, which is a paragon of disorder. This case supports many aspects of the theory: it shows that a predatory market association can persist for a surprisingly long time, and it documents the hurdles to overthrowing such a leader. In one important respect, however, this case is inconsistent with the argument: despite facing an external threat, the market association has not been motivated to use its strength to promote trade. I will explore some explanations for this at the end of the section, and discuss recent market association-local government collusion.

\subsubsection{In what ways is this market disorderly?}

While the market's constitution stipulates that a goal of the association is to prevent "internal suppression,"10 and many provisions of the constitution seem to be intended to protect the property rights of market traders, in fact the association itself violates the property rights of traders. The association has been known to lease the same shop to multiple traders and "let them fight it out."11 It will also stop collecting fees from a trader who has been in the market for a while - now a commonly known

\footnotetext{
10 The Reviewed Constitution/Bye Law of Ladipo International Auto Spare Parts Market. 2012. Page 3

${ }^{11}$ Interview with Yusuf Omotayo, reporter for naijj .com, on March 22, 2016.
} 
sign that a traders is "about to be booted," and a few weeks later it will be revealed that the shop has been granted to someone else in violation of a lease agreement. ${ }^{12}$

By reading the market's constitutions one could be misled to think that Ladipo Main Market has pro-trade institutions, such as dispute resolution mechanisms. If a customer buys a product - for example a used engine - it might not be functional at the time of sale, and both the trader and customer know this. It should, however, be fixable. The customer has seven days to get it fixed. ${ }^{13}$ If it cannot be fixed, the customer can bring the engine back to trader. The trader is obligated to invest some effort into resolving the situation. This is usually accomplished by asking the customer to pay a little extra money and replacing their engine with a better one. Formal appeals processes within Ladipo Main Market in theory backstop this process.

In reality, however, there is a notable absence of impartial dispute resolution institutions in the market. The association tends to side with its own traders - a strategy that benefits an individual trader in the short-run but hurts all traders in the long-run as the market fails to develop a reputation where customers cannot be assured that they will not be cheated. One trader told me the association will give its own trader "all of the honor" in such disputes, and that "the union gives you a soft landing with customers."14

Further, the market association does not facilitate information sharing about dishonest customers - customers who make purchases on credit and never repay, a common and important problem for market traders. In theory, the association should be able to facilitate the sharing of this sort of information. After all, there is a com-

\footnotetext{
12 Ibid

13 The Reviewed Constitution/Bye Law of Ladipo International Auto Spare Parts Market. 2012. Page 61

14 Interview with market trader on January 18, 2016.
} 
mittee within the market that deals with complaints about customers. They should be able to identify customers who have a disproportionate number of complaints. But the market association does not share any information about potentially dubious individuals.

Public extortion is also a problem for Ladipo Main Market traders. Mushin Local Government, where Ladipo is located, hired a thug to collect local government fees from the Ladipo traders. In early 2016 the traders realized that this agent was collecting more than the local government had authorized. "[The thug] and his boys are being used by the local government authority to extort money from us daily and they have become a thorn in our flesh," one trader said. "At times, I pay N500 [\$2.07] in a day."15 In February 2016 traders rioted against the thug. Exactly what happened during the riot is difficult to ascertain, but at least one trader died, possibly from a stray bullet fired by traders to deter police involvement. ${ }^{16}$ In short, conditions have been tense.

Moreover, as of April 2016, Ladipo Main Market is closed. When I visited the market on an ordinary Monday morning in January 2016 the road in front of the market was packed with street vendors - traders who used to have shops in the market, but were now selling on the road. A man wove through the traffic carrying a car bumper on his head. Traders who sold products that could not be exposed to the elements, like car engines, stored their engines in nearby warehouses, waiting for regular customers to call them with inquiries. Just months earlier they had shops in the market, getting foot traffic from fist-time customers as well.

The street vendors had constricted a formerly two-land road into a street where

\footnotetext{
${ }^{15}$ Hanafi, Azeez. 2016. "One dies as Ladipo traders clash with soldiers." Punch. February 26.

${ }^{16} \mathrm{Ibid}$
} 
you often had to pull over to the side to let cars going the other direction pass. The traffic to get through the commercial area was bad, even for Lagos. My taxi driver and I moved perhaps 100 feet in 30 minutes. The driver grumbled periodically that this was why he never came here.

Why are things so bad in Ladipo? In short, it is because Ladipo is governed by a strong market leader who uses his strength to predate. Before explaining this further, let me provide some background information on Ladipo.

\subsubsection{What is the Ladipo Main Market?}

Ladipo is a dense commercial area in the middle of Lagos, where thousands of traders sell used vehicle spare parts from Japan, Hong Kong, Malaysia, and elsewhere. An umbrella association, the Ladipo Central Auto Dealers Association, governs the entire area, and Ladipo Main Market is one of 42 units - each with its own association - in the area. As its name suggests, Ladipo Main Market is the primary unit.

While many markets in Lagos are ethnically diverse, the vehicle spare parts trade has historically been dominated by people from one group, the Igbo ethnic group, which predominates in the southeastern part of the country. Ethnic homogeneity alone, however, is not sufficient for unity. Traders divide themselves into "constituencies" which are based on which state in the Southeast one's family is from. There is a constituency of traders from Abia State, for example, and Imo State. The market leader, Jonathan Okoli, is from Anambra State, and traders perceive the association as being dominated by the Anambra constituency.

Ladipo Main Market has two main groups: Trader's Voice, the market's ruling group, headed by Okoli, and the Opposition. I capitalize "Opposition" in this context 
as the word is used by traders to reference an organized group of traders within the market.

\subsubsection{Why is the market closed?}

In spring 2016, the first order issue facing Ladipo was the closure of their market. How did this come to be? There are two main reasons: first, the market association colluded with the local government, and second, prior to the collusion, the market association was not able to mobilize traders to protest as one to fight efforts to reconstruct the market.

\section{Collusion}

Collusion between market associations and government officials is empirically rare in Lagos. Looking at data from the ongoing second panel of the 2015 survey, traders report that there has been collusion between the market association and local government in 12 of the 141 associations represented so far. In 2015, however, the Ladipo Main Market association colluded with the local government. This incident sheds some light on the conditions that might make collusion more likely, and helps to explain why it is so difficult for traders to overthrow predatory market leaders. The short version of what happened is as follows: Facing the prospect of being overthrown by traders, the market leader colluded with the government to support an action that would hurt the market but allow the market leader to remain in power.

The Lagos State Government has a broad mission of "modernizing" markets throughout the city - taking "traditional" markets and putting multi-story plazas in their place. ${ }^{17}$ Cynics see this effort as motivated not by a desire for better sanita-

\footnotetext{
17 Similar efforts can be found throughout West Africa (Prag, 2010).
} 
tion but rather as an effort to control markets. It is difficult to infiltrate an existing association. What is easier is to create a new market that most of the original traders are priced out of, and influence the structure and leadership of the new association.

Whatever the true motivation, as part of the mission to modernize markets throughout Lagos, the local and state government have been trying to renovate the Ladipo Main Market for years. In addition to the risk of being priced out of the new market, market renovations typically take months if not years, and traders are displaced during construction. For years the Ladipo Main Market association had successfully resisted government attempts to renovate the market.

Even though the market association is predatory, the traders' and market leaders' interests were aligned when it came to the renovation efforts: no one wanted it to happen. The market leader, after all, would likely lose his ability to collect fees from traders while the market was being reconstructed. But the pressure from the government was intense. As such, the market association began negotiating with the local government for a renovation plan that would minimize disruption to trading. A compromise was reached, and the market association brought the proposal to the traders. The traders vehemently rejected the plan, and in a rare instance for Ladipo of market association responsiveness, the association told the local government they could not proceed.

However, on June 29, 2015 at 6:00 AM, when traders were at their homes, the local government entered the market "by force," a local way of describing government action without the consent of organized societal groups. They tore the roofs off many shops in the market - a particularly drastic move as it was during the rainy season, and rain can damage certain spare parts like engines. When traders arrived, they were prohibited from entering the market. Parts of the market was looted, and when 
traders were finally able to re-enter many found that money they kept in their shops had been stolen. The market association sued the local government and developer, alleging malicious damage of property and illegal eviction of traders. ${ }^{18}$ The association simultaneously came to a negotiated settlement that would allow the traders to continue to trade on the streets during the construction. Both the market leaders and traders agreed to this, as there was no other option. The local government had signaled they were willing to take action without consent.

Meanwhile, the current market leader had won reelection in 2014, but the Opposition within the market felt the elections were not free and fair. Opposition members had been disqualified from vying for leadership positions on the grounds that they had misappropriated finances when they had held office previously. The Opposition had approached the Board of Trustees, the market elders, to complain about the situation. The Ladipo constitution stipulates that the Board of Trustees "[s]hall be the organ to mediate on electoral issues whenever there is crisis in election and their decision is final."19 The elders supported the incumbent. In contravention to the constitution - though whether such a provision prohibiting taking market electoral disputes to the government is legal is questionable - the Opposition filed a case in court challenging their disqualification. The court granted the request to annul the elections, but the market leader appealed. As of January 2016, the appeal was still being processed and the market leader remained in power. This process provides evidence for the hurdles to overthrowing a market leader. Even if the traders are able to raise the necessary funds to file a court case, the process might take so long that by

\footnotetext{
18 Odekanyin, Ayomide Owonibi. 2016. “Ladipo Traders Head to Court Against Mushin LG." July 13. www.tribuneonlineng.com/ladipo-traders-head-court-against-mushin-lg

19 The Reviewed Constitution/Bye Law of Ladipo International Auto Spare Parts Market. 2012. Page 48.
} 
the time any enforceable ruling comes about the market leader will have served the majority of the term.

While the case was being appealed, however, the Opposition approached the local government chairman. This was unusual. Market leaders liaise with government officials. It is typically unacceptable for traders to negotiate directly with government officials.

The Opposition told the local government that they should no longer negotiate with the former market leader. His election had been annulled. The local government was of course upset that the market association was suing them, so they were happy to go along with the plan.

Okoli was dismayed to learn that the local government was no longer acknowledging him as the market leader. He went to the local government, and essentially asked what he could do to get back on good terms with the local government. The local government said he would have to withdraw the market's court case protesting the renovation. The market leader complied, selling out the market to remain its leader.

This account provides one potential explanation for when we will observe collusion between a group association and the government. While one might think that collusion would be constrained by the threat of collective anger, here, collusion emerged when the association felt like it was about to lose control. The only option to maintain power was collusion.

\section{The failure to mobilize traders}

Why wasn't the market able to resist the local government construction efforts in the first place? Because the market association never had the support of all traders, 
it struggled to mobilize traders to fight back against the construction efforts. The market did organize protests, but getting the Opposition members to protest, "this was a very big problem." ${ }^{20}$ It was only when the local government tore the roofs off of the shops that the Opposition members supported the protest efforts.

This is compelling evidence, consistent with the theory, that associations struggle to mobilize traders without their sympathies. As a local reporter told me, the market's "inability to be strong as a house affects the union [i.e. association]." 21

\subsubsection{In the face of an external threat, why did the association continue extorting?}

While the case of Ladipo Main Market is consistent with many aspects of the theory, my theory expects that when strong associations face external threats, they will be motivated to not extort from their own members. If they extort, they won't be able to mobilize members to fight back against the threat.

The Ladipo Main Market association faced a severe external threat, namely the threat of reconstruction. Yet the association has never ceased extorting. As I expect, the association was not able to fend off the threat because it could not mobilize traders. But why didn't it stop extorting? The answer is not obvious. One might think that because the association colluded with the local government, there was no threat, per se. However, there is no evidence of collusion until very recently. For years the association was threatened by the local government and continued to extort.

One possibility is that the market leader perceived fending off reconstruction as a hopeless endeavor. This could have shortened his time horizon, and motivated him to simply continue to extort until the moment he lost power.

\footnotetext{
${ }^{20}$ Interview with trader on January 18, 2016

${ }^{21}$ Interview with Omotayo Yusuf, reporter for naijj .com, on March 22, 2016.
} 


\subsubsection{Formal private governance institutions are not sufficient for order}

Much work on private order emphasizes how formal private governance institutions affect order. For example, Peter Leeson's work on pirate governance argues that pirates organized their banditry and constrained private extortion with democratic constitutions (2007). I propose that this line of work leaves unanswered the critical question of how democratic constitutional provisions came about in the first place, and second, it overstates the importance of formal rules. Private rules can be manipulated to serve the interests of group leaders in the absence of a check on the power of group leaders. The actual balance of power across societal groups matters at least as much as formal rules, and at minimum, private democratic constitutions are not sufficient for private order. Ladipo Main Market illuminates how even formal and highly institutionalized rules can be modified.

Ladipo Main Market has had a constitution since 1992. In 2012 the market leader succeeded in efforts to introduce a new constitution. This success is on its face puzzling. Successive constitutions have mandated that two-thirds of traders support any changes to the constitution, and the traders were largely opposed to the proposed constitutional changes, and more broadly opposed to the market leader. So how did the market leader succeed?

The market leader, in short, bought off powerful brokers in the market. He brought these brokers to a hotel in Festac, a wealthy area in the western part of Lagos state. He wined and dined these elites and "gave them very reasonable envelopes $^{\prime 22}$ with an acceptable amount of naira. The brokers then endorsed the new constitution. On their return to the market they spoke with traders and convinced them to support the new constitution.

\footnotetext{
${ }^{22}$ Interview with market trader on January 18, 2016
} 
The constitution effectively centralized power in the market leader. For example, the new constitution stipulated that candidates for market leader have running mates who would become the vice chairman. Previously the individual who received the second highest number of votes would become the vice chairman. This individual, who would typically be from the Opposition, served as a check on the power of the chairman. Now, the "chairman is an island," one trader told me, "he can use money as he wishes." 23

\subsection{A failing market governed by a weak market association}

\begin{tabular}{c|l|l|}
\multicolumn{1}{c}{ Strong assoc. } & \multicolumn{1}{c}{ Interventionist government } & \multicolumn{1}{c|}{ Non-interventionist government } \\
\cline { 2 - 3 } Weak assoc. & $\begin{array}{l}\text { Market: Dabiri } \\
\text { Argument predicts: Predatory } \\
\text { govt., few pro-trade institutions } \\
\text { Observed: Predatory govt., } \\
\text { few pro-trade institutions }\end{array}$ & \\
\cline { 2 - 3 } & & \\
\hline
\end{tabular}

In this section I look at a market that I call Dabiri. Like Ladipo, Dabiri does not have pro-trade institutions, but unlike Ladipo, the Dabiri market association does not extort from its members. The theory predicts that public extortion will plague markets that face state threats and lack strong associations to defend themselves, and that is what we see in here. This section further explores why a well-liked, wellintentioned market leader is not sufficient for order.

\footnotetext{
23 Interview with market trader on January 18, 2016
} 


\subsubsection{Disorder in Dabiri}

In Dabiri, public extortion is a problem: in 2014 the local government increased taxes $100 \%$ "by force." 24 The traders pay a confusing plethora of fees that they often do not understand sufficiently to explain to an outsider. Moreover, the market leader takes a hands-off approach to market management. This translates both into no private extortion, but also no institutions that could support contractual trade. One trader said he had never heard of the market leader being called on to resolve a dispute between a supplier and a trader. ${ }^{25}$

Worse still, the market is plagued by the illegal presence of hawkers on the main road outside the market. The hawkers sell the same products that the market traders sell, tempting customers to stop on the main road and buy vegetables and provisions from the hawkers instead of going to the trouble of parking and entering the market. The market's inadequate drainage system further motivates customers to buy from hawkers. After even the lightest of rains, walking around the market involves being shin-deep in water. The hawkers can also sell at lower prices than the traders because they do not need to pay rent. Every time I visit the market, traders I interviewed during my previous visit are nowhere to be found, having gone out of business in part due to the hawkers.

\subsubsection{Evidence that Dabiri is governed by a weak association and located in an interventionist local government}

The Dabiri market association has been weak since its start, in part due to divisions in the market. In the early 2000 s local traditional leader, or king, provided

\footnotetext{
24 Interview, Sept. 26, 2014

25 Interview, Jan. 11, 2014
} 
the market's land to the local government. When the market was built, the king was given allocation papers for several of the shops to distribute as he wished. Similarly, the former local government chairman was given allocation papers which he gave to supporters and members of his family. The remaining shops' leases were sold competitively. Many of the primary lease holders leased their shops to other people, either because they were living abroad or too busy to manage a shop, but some primary lease holders are themselves the traders who work at the shops. This diversity of ownership status among the active traders in the market has caused frequent disputes over how to respond to increases in taxes and fees that come from the local government. Secondary lease holders might not be opposed to a fee that would affect the primary lease holders, and vice versa. When there is uncertainty over whether a fee would affect primary or secondary lease holders, there are further disputes. These divisions are extremely salient in the market, and are one of a number of factors that have prevented the market leader from effectively organizing the traders.

Dabiri is in a local government with several powerful traditional families, and zoning institutions predominate for elected office. It is accepted that the local government chairman will always come from one traditional family, while the state representative will always come from a different family. Other families of prominence will be appointed as supervisors in the local government. In 2014, when this market was researched, the local government chairman was in his $40 \mathrm{O}$ and ambitious. He was in his second term, and planning to run for a third. If he does not win, he aspires for state office. Either way, he aims to increase the local government's internally generated revenue, a critical metric on which the godfather judges local government chairmen. In short, he is an interventionist chairman. 


\subsubsection{Why a well-liked market leader is not sufficient for order}

The Dabiri market leader was elected in free and fair elections, and is well-liked among traders. Traders value her education - she has a masters degree in secretarial studies from the UK - which is often perceived as an important characteristic in a market leader, as market leaders must negotiate with government officials.

So the market leader is well-liked and well-intentioned. Why isn't that sufficient for order? One problem is that the market leader takes a hands-off approach to market management. She has several other businesses besides her shop in the market and, for better or worse, does not intervene much in market affairs. No trader I spoke with could recall a time she was called on to resolve a dispute between a supplier and a trader, mostly because she is only rarely even at the market.

Mancur Olson has seminally argued that a leader's time horizon affects the likelihood private order. When a leader has a long time horizon she will be motivated to protect group members from outside predatory actors, and also be motivated to herself not extort. She will want group members to be productive so as to maximize long-term tax collection.

The Dabiri market leader is subject to terms and term limits, so she likely has a short time-horizon. But this case highlights the fact the even if she had a longer time horizon, her other businesses can alter incentives. If the other businesses are more productive than the market, it might make sense for her to continue focusing on these outside businesses and spend little time in the market (Ostrom, 1990).

\subsubsection{Why the local government will not get rid of hawkers}

The local government, which has its secretariat physically adjacent to the market, refuses to get rid of the hawkers. There is no question of their capacity to remove 
the hawkers if they wished to given their proximity to the market. Local government officials can probably see the hawkers from their windows. The local government has refused to get involved because the local government chairman has wanted to destroy the market and build a multi-story modern market.

In most cases where the local government is interventionist and the market association weak, market renovation would have already happened by now. But because of the involvement of the traditional ruler, who has an interest in protecting the leases of his friends and family, this has not happened. Unhappy with their stymied renovation efforts, the local government has refused to force the hawkers to leave, hoping to put traders in the market out of a business. Indeed, this appears to be happening. A DVD trader who was in the market in January 2014 had gone out of business by September 2014, unable to compete with the hawkers who sold DVDs more cheaply.

The case of Dabiri reveals that external threats are not sufficient for order. If the market association were stronger - if their lease-holding divisions were not so salient, if the market leader had no other businesses - the association might be motivated and able to mobilize traders, perhaps to protest the hawking situation at the state government secretariat. But because such mobilization is not feasible, the market leader has made calls to state government officials to complain about the hawkers, the state officials have made half-hearted attempts to get rid of the hawkers, such as sending people to remove them one day, only to have the hawkers return the next day. The market has not been able to demand that the state government take more drastic action, which could involve compelling the local government to take more action, or sending the hawker removers more frequently. In short, the market's inability to threaten politicians impedes market order. 


\subsection{Why not leave? And why join in the first place?}

Traders in Ladipo Main Market and Dabiri encounter public extortion, and there is an absence of private order institutions such as information sharing about dishonest customers. "Really, things had been so bad in Ladipo," one Ladipo trader told me. "But the possibility of traders thinking of relocating to other markets is not an easy task." ${ }^{26}$ Why is this? Why don't traders leave and relocate to a different market?

As a spare parts seller, it is best to be in a market that sells other spare parts. If customers go to a market where only one shop sells spare parts, they will feel like they lack the ability to bargain. Customers prefer to go to markets where they can shop around and compare prices. Ladipo is one of two big spare parts markets in Lagos, and the only one that is centrally located. As such, the exit options are limited.

Dabiri, however, is a general market selling a wide variety of products, so this constraint is not operative. But for two main reasons even at Dabiri it is not easy for traders to leave. First, advance rent is the norm in Lagos, as in many cities in the developing world. Traders must pay typically two years of rent up front to rent a shop. Whatever a trader's monthly rent, two years of advance rent is a huge amount of money. After renting for two years, the norm is that only one year of rent must be paid up front for subsequent years. This greatly dis-incentivizes relocation. Second, perhaps in part due to political uncertainty in Nigeria more generally, there is often hope that conditions in a market will improve. Third, prior to joining a market, a trader has imperfect information about conditions in the market. Dabiri is a market that is unequivocally an undesirable market to be in, yet while conducting research there I met three women who were submitting their documents to lease a shop in the market.

\footnotetext{
${ }^{26}$ Interview with market trader via Facebook Messenger on April 19, 2016.
} 
Why don't the traders join together and start up their own new market? This would seem an especially attractive option in Ladipo given that opposition to the market leader is widespread. Starting a new market, though, would be exceptionally difficult. Space in Lagos - the most densely populated city in Africa ${ }^{27}$ - is tight.

While one might think these constraints are specific to markets in Lagos, sorting into new groups is costly in most contexts. If you belong to a furniture manufacturing association in a city, it is unlikely there is an additional furniture manufacturer association you could join if you were dissatisfied with your current one. Starting a new association could be tricky for many reasons. Perhaps the current association is already the recognized association for negotiations with a municipal government. Lobbying the government to negotiate with an additional association might not be straightforward.

\subsection{Conclusion}

In this chapter I presented evidence from an orderly market that was consistent with the argument: the market association coordinated in-group policing and facilitated information sharing to reduce disputes that would provide the opportunity for a regulatory agency to interfere in market affairs. The association does not extort from its own traders, allowing it to mobilize traders to fend off threats of tax hikes. I also showed that predatory market associations can hold on for years. By looking at an instance of collusion, I proposed that collusion may occur in rare cases when the market leader faces the prospect of being overthrown by her traders. The chapter presented examples of the idiosyncratic sources of market association strength, such as diversity in ownership status over shops. I concluded by discussing the obstacles to

27 citymayors.com/statistics/largest-cities-density-125.html 
sorting into markets, including multi-year advance rent requirements and imperfect information about conditions inside a market.

Edward Stringham states that "the more seamless private governance is, the fewer people notice it or appreciate its beauty. Private governance is so often missed" (2015, p. 8). I disagree. There is an abundance of research on private governance, on groups that resemble Oke-Arin, the case of market order. This leads to the incorrect assumption that it is ubiquitous when in fact groups like Ladipo and Dabiri abound. Private order should be considered unusual, and its presence must be explained. 


\section{TESTING THE THEORY WITH HUNDREDS OF LAGOS MARKET ASSOCIATIONS}

In the previous chapters I laid out a theory for the conditions that make private group order more likely and discussed how to conceptualize and identify market associations empirically. I then tested the theory on three markets to illuminate the micro-dynamics in these markets. In this chapter I use the survey data to assess whether implications of the theory hold when looking at a larger number of markets in Lagos.

To summarize my theory, I argued that strong associations - meaning associations that are able to control the internal affairs of their group - can use their strength to predate on group members or to promote order within the group. Strong associations will be motivated to use their strength to promote order when they face the prospect of government intrusion. Threats from the government motivate group order because 1) the association needs to minimize group disputes to reduce the likelihood of state intervention, and 2) the association needs the support of group members to mobilize against state threats.

This leads to the following testable hypotheses. First, I expect that attributes of private order should be positively correlated. I expect that the bundle of private good governance institutions should be a result of the same factors, even though some of these institutions might seem distinct, such as private extortion and information sharing. Second, I expect that among strong market associations, local government 
interventionism should be associated with private order institutions. Third, markets on local government land face many more threats from the government. I look at the relationship between the type of land the market is on and private order institutions, testing the hypothesis that markets on local government land will be more orderly than markets on private land.

Next, I look for evidence of the mechanisms, expecting that market association good governance should be associated with political engagement. This is because associations that extort from their members should not be able to mobilize them to vote as a block. Politicians, then, will not be expected to visit these markets seeking market leader endorsements.

Finally, I use the survey data to assess additional explanations for private order.

The key findings are that among strong market associations, private extortion is less likely when the market is under the jurisdiction of an interventionist local government. Market associations are more likely to facilitate information sharing among traders if the market is on local government land. And well-governed markets are substantially more politically engaged than badly governed markets.

One important limitation to this analysis is worth noting. Through interviews I made the assessment that the two most common types of external threats markets face are being in an interventionist local government and being on local government land. But this is not the universe of state threats. Chapter 3, for example, discussed how threats of intervention from the National Agency for Food and Drug Administration and Control was a relevant external threat for Oke-Arin. The survey is not able to capture the universe of possible state threats these markets face. 


\subsection{Measuring variables}

In this section I describe how I measure variables in the survey. Appendix B lists the actual survey questions used.

\section{Explanatory variables}

Market association strength. Market association strength is defined as the ability of an association to control the internal affairs of the market. I measure it as an index averaging two variables. The first is whether traders report that the market association holds regularly scheduled meetings for traders. Control requires the clear communication of rules, and market meetings are the channel for this communication in Lagos markets. The second variable comes from a survey question where enumerators asked traders to name the main market association they belonged to. These associations were almost always physically-delimited associations, such as an association for the plaza or cluster of plazas, or an association for a more traditional market. In some cases, though, traders reported not belonging to any association. Enumerators were trained over two weeks of formal training (along with refresher trainings throughout survey implementation) on how to follow up on these responses, such as asking about to whom the trader pays trash collection fees. For traders in some markets the ultimate answer was that a landlord or caretaker association performs these functions. This second variable takes a o (weak) for these cases, and otherwise a 1 (strong).

This latter measure has advantages and disadvantages. The important advantage is low measurement error. Markets with traders who reported that the only association was a caretaker association are undoubtedly weak. The word caretaker itself implies a narrow sphere of control. It is possible for landlords to be strong, but strong 
landlords are typically called market presidents. The word landlord, in the Nigerian market context, implies someone who is simply collecting rents and basic fees.

The disadvantage to this measure is that it captures perhaps not just weak associations, but also no associations. An association, however, is simply an entity that governs a group. Market landlords in the Lagos context perform this role. Landlords or caretaker associations might not be able to resolve disputes inside the market, but they are responsible for making sure bills get paid and that traders follow basic market rules, such as closing the shops around sunset. Indeed it is especially important to capture these exceptionally weak associations, as missing them would mean falling into the trap that many studies of private order fall into, namely focusing only on successful groups.

Local government interventionism. The theoretical concept I aim to capture here is the idea that some governments are engaged with communities, often trying to extract revenue, and others are not. I am agnostic as to whether the local government is intervening with the goal of pursuing private gain or societal interests. The point is that in developing countries, where local governments lack a track record of good governance, any sort of intervention is typically seen as threatening. Indeed even if a market knew that the local government was intervening to pursue the interests of the community, this might still be threatening as market interests are not always aligned with societal interests.

Traditional measures of government capacity are not appropriate for a variety of reasons, including the fact that the concept is distinct from interventionism. Conventional measures look at service provision; Cleary (2007), for example, uses presence of potable water and sanitary sewerage. This is problematic for my purposes for three reasons. First, the tenure of chairmen is three years. No chairman has ever served 
more than three terms and $35 \%$ of the chairmen in 2014 were in their first term. It would be difficult to determine whether services existed before a chairman came to power. Second, looking at local government service provision at the market level is problematic, as this could be correlated with the political value of the market. Third, I want to call chairmen interventionist irrespective of whether they provide services or predate - focusing on service provision would have me incorrectly labeling chairmen who predate as non-interventionist.

As such, I measure local government interventionism by looking at whether the local government chairman involves herself/himself in market disputes, a question that was asked in the survey of local government revenue collectors. The advantage of this measure is that it is not capturing a concept that is defined by the strength of societal groups. It is capturing whether the local government is motivated to involve itself in market affairs. A potential concern is that chairmen choose not to involve themselves in disputes in markets governed by strong associations. However, because there is great variation in market association strength among markets in a local government, I am not worried that one strong market association that prevents the chairman from interfering in their affairs would drive the response to this question.

\section{Outcome variables}

Private extortion. Private extortion here means market association extortion of traders. I measure private extortion with a low-measurement error question: traders were asked whether they feel the market association accounts properly for fees it collects. This question was developed by listening to words traders used to talk about market association management. Associations that, for example, collect fees for electricity but pocket these funds would not be accounting properly. The main advantage to 
this question is that responses can be interpreted consistently across associations. Other pro-trade institutions. I look at several other variables to capture the presence of pro-trade institutions. First, I look at whether traders report that the market association represents their interests, the closest approximation to market good governance in the absence of data about the particular issues facing each market. Second, I look at whether market leaders warn traders about opportunistic customers - customers who receive products on credit and do not repay. I focus on this outcome because it is equally valuable in all types of markets. Some of the other variables, such as whether the market association warns traders about opportunistic suppliers, are only relevant in markets where traders source their products domestically. The other advantage to focusing on information sharing about customers is that it is an example of a market institution that is costly in the short-term, where one would expect traders to not want to share information with their competitors about opportunistic customers. Third, I look at whether the market association helps to resolve disputes in the market. I wrote almost all of these as yes or no questions to reduce measurement error.

When I am not testing an argument that is explicitly about a certain type of institution I will use a market association good governance index. The index averages responses of traders in the association to questions about whether the association: 1) represents trader interests, 2) accounts honestly for the fees it collects, 3) warns traders about dishonest customers, and 4) helps to resolve disputes.

\section{Controls}

I control for factors that have been shown to affect group cooperation. One of the more dominant alternative explanations focuses on diversity (e.g. Habyarimana, 2009). I develop a market ethnic heterogeneity variable by creating a herfindahl index 
of ethnic diversity based on the ethnicity of the traders interviewed in each market. I also control for the education level of traders in a market, whether market leaders hold their position for life, and whether market leaders are elected. These data come from the surveys.

\subsection{Descriptive statistics}

\begin{tabular}{lccccccc}
\hline \hline Statistic & N & Mean & St. Dev. & Min & Max & $\begin{array}{c}\text { Mean } \\
\text { public land }\end{array}$ & $\begin{array}{c}\text { Mean } \\
\text { private land }\end{array}$ \\
\hline Outcomes & & & & & & & \\
Representative & 258 & 0.69 & 0.25 & 0.00 & 1.00 & 0.70 & 0.66 \\
Warns about customers & 258 & 0.44 & 0.40 & 0.00 & 1.00 & 0.46 & 0.41 \\
Helps resolve disputes & 199 & 0.37 & 0.41 & 0.00 & 1.00 & 0.49 & 0.35 \\
Honest accounting & 241 & 0.81 & 0.30 & 0.00 & 1.00 & 0.83 & 0.78 \\
Explanatory variables & & & & & & & \\
Assoc. strength (1) & 264 & 0.59 & 0.45 & 0.00 & 1.00 & 0.46 & 0.66 \\
Assoc. strength (2) & 269 & 0.97 & 0.18 & 0 & 1 & 1 & 0.93 \\
LGA interventionism & 52 & 0.20 & 0.37 & 0 & 1 & & \\
Controls & & & & & & & \\
Education level traders & 266 & 0.44 & 0.39 & 0.00 & 1.00 & 0.38 & 0.45 \\
Elected leader & 202 & 0.90 & 0.30 & 0 & 1 & 0.98 & 0.84 \\
Leader for life & 229 & 0.20 & 0.40 & 0 & 1 & 0.37 & 0.14 \\
Market ELF & 125 & 0.31 & 0.20 & 0.00 & 0.65 & 0.37 & 0.27 \\
\hline
\end{tabular}

Table 4.1: Summary statistics by market association. The local government (LGA) interventionism variable is the only summary statistic in this table that is not by market. LGA interventionism measures whether the local government involves itself in market disputes. Market association strength 1 measures whether the market association holds regularly scheduled meetings for traders, and market association strength 2 measures whether traders report only a landlord/caretaker association (in which case the variable takes a o). Markets on public land references markets on local government land. Markets on federal government land are included in overall summary statistics, but not in the two final columns. 


\section{$4 \cdot 3$ Results}

\subsubsection{Pro-trade institutions are not common}

I argued that there are hurdles to pro-trade institutions such as information sharing and in-group policing. As such, the presence of these institutions cannot be assumed. The implication is that these institutions should not be exceptionally common, and that is what we see in the data. In only $27 \%$ of the markets does the modal trader report that the association facilitates information sharing about dishonest customers. The mean representativeness score for associations is 0.59 (on a scale of o to 1), which is not exceptionally low, but also does not imply that when associations are needed they will emerge and represent the interests of group members.

\subsubsection{Attributes of market good governance are positively correlated}

A first-order implication of the argument is that attributes of market association good governance should be positively correlated. Figure 4.1 shows that, indeed, when traders say the market association represents their interests or accounts honestly for the fees it collects the market association is much more likely to provide trade-promoting institutions like information sharing.

\subsubsection{Strong market associations more likely to intervene in disputes, but not otherwise more likely to govern better}

Table 4.2 suggests that a strong association should not be sufficient for private good governance. Table 4.3 tests this prediction, looking at the relationship between market association strength and association good governance. We see that while 

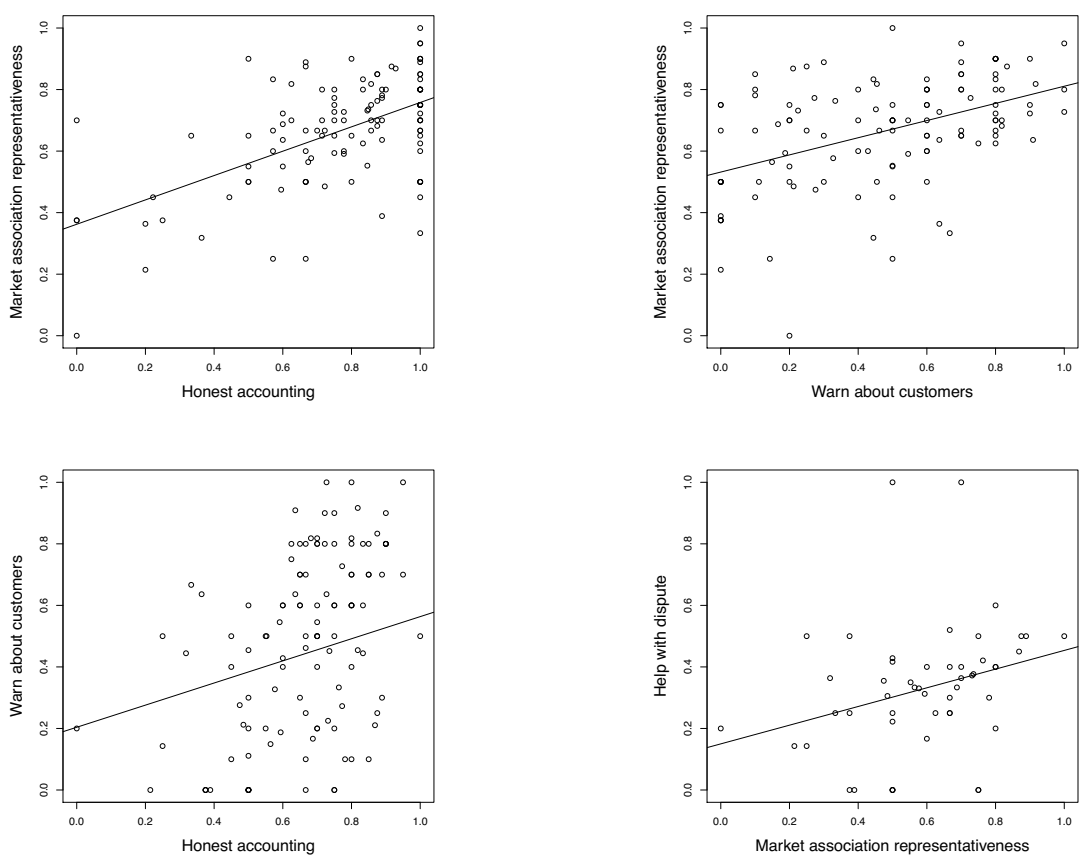

Figure 4.1: Attributes of good market governance are positively correlated. When traders perceive that the market association represents their interests and accounts honestly for the fees they collect, for example, traders are also more likely to say the market association warns traders about opportunistic customers. Each dot represents the mean response among traders in a market. I have subsetted the data to include only market associations with at least three respondents.

Table 4.2: Predictions of the argument

Interventionist government Non-interventionist government

\begin{tabular}{l|l|l} 
Strong association & Private extortion: Low & Private extortion: High
\end{tabular} Pro-trade institutions: High $\quad$ Pro-trade institutions: Low

Weak association

Private extortion: Ambiguous Private extortion: Ambiguous Pro-trade institutions: Low Pro-trade institutions: Low 
markets with strong associations score better on the good governance index, this relationship is driven entirely by one component of the index: whether the association helps to resolve disputes in the market. However, associations could intervene in disputes to predate - indeed dispute resolution is a primary source of revenue for market leaders, as traders typically pay a feee when the association involves itself in a dispute. When considered in light of the other components of the index, column 2 suggests that strong market associations are more likely to be activist associations, but, consistent with the argument, it is ambiguous to what end they will utilize their strength.

Table 4.3: Association strength alone is not sufficient for private good governance. Column 1 looks at the relationship between association strength and good governance. Columns 2-5 look at each component of the good governance index. While strong market associations score higher on the association good governance index, the relationship is driven by the component of the index that considers whether the association helps to resolve disputes. When considered apart from the other components of the index, this variable on its own does not signify good governance, as meddling in disputes could be for non-benevolent reasons.

\begin{tabular}{lccccc}
\hline \hline & \multicolumn{5}{c}{ Dependent variable: } \\
\cline { 2 - 6 } & $\begin{array}{c}\text { Assoc. } \\
\text { gov. index } \\
(1)\end{array}$ & $\begin{array}{c}\text { Help w/ } \\
\text { disputes }\end{array}$ & $\begin{array}{c}\text { Honest } \\
\text { accounting }\end{array}$ & $\begin{array}{c}\text { Represent- } \\
\text { ativeness }\end{array}$ & $\begin{array}{c}\text { Warn about } \\
\text { customers }\end{array}$ \\
& $(2)$ & $(3)$ & $(4)$ & $(5)$ \\
\hline Assoc. strength & $0.193^{* * *}$ & $0.344^{* * *}$ & 0.108 & 0.069 & 0.147 \\
& $(0.049)$ & $(0.109)$ & $(0.082)$ & $(0.064)$ & $(0.100)$ \\
Constant & $0.370^{* * *}$ & 0.090 & $0.721^{* * *}$ & $0.636^{* * *}$ & $0.317^{* * *}$ \\
& $(0.040)$ & $(0.095)$ & $(0.066)$ & $(0.052)$ & $(0.082)$ \\
\hline Controls & No & No & No & No & No \\
Observations & 264 & 194 & 239 & 254 & 254 \\
$\mathrm{R}^{2}$ & 0.055 & 0.049 & 0.007 & 0.005 & 0.009 \\
\hline \hline Note: & & & & ${ }^{*} \mathrm{p}<0.1 ;{ }^{* *} \mathrm{p}<0.05 ;{ }^{* * *} \mathrm{p}<0.01$
\end{tabular}


4.3.4 Among strong market association, the threat of state interference is associated with pro-trade institutions

Recalling that the theory offers clear predictions about the level of private extortion among strong market associations (table 1.2), in the first empirical test of the argument I assess the relationship between local government interventionism and pro-trade institutions among strong market associations (table 4.4). The results suggest that in this subset of the markets, pro-trade institutions are more likely in markets in interventionist local governments.

Table 4.4: For markets with strong associations, being in an interventionist local government is associated with traders being more likely to report that the association accounts honestly for the fees it collects. Controls include whether the market leader holds their position for life, market ethnic diversity, and the education level of traders in the market. The data is subsetted to 1) markets with associations that score greater than 0.5 on the association strength index, and 2) markets where I have interviews from 3 or more traders. Due to the small $\mathrm{N}$ of this subsetted dataset, it is not possible to incorporate local government fixed effects here.

\begin{tabular}{|c|c|c|c|c|}
\hline & \multicolumn{4}{|c|}{ Dependent variable: } \\
\hline & \multicolumn{2}{|c|}{$\begin{array}{c}\text { Honest accounting } \\
>0.5 \text { on strength index }\end{array}$} & \multicolumn{2}{|c|}{$\begin{array}{c}\text { Info sharing } \\
>0.5 \text { on strength index }\end{array}$} \\
\hline & $(1)$ & (2) & (3) & (4) \\
\hline Local govt. interventionism & $\begin{array}{l}0.161^{*} \\
(0.085)\end{array}$ & $\begin{array}{l}0.142^{*} \\
(0.078)\end{array}$ & $\begin{array}{l}-0.101 \\
(0.102)\end{array}$ & $\begin{array}{l}-0.066 \\
(0.100)\end{array}$ \\
\hline Constant & $\begin{array}{c}0.752^{* * *} \\
(0.032)\end{array}$ & $\begin{array}{c}0.778^{* * *} \\
(0.072)\end{array}$ & $\begin{array}{c}0.549^{* * *} \\
(0.038)\end{array}$ & $\begin{array}{c}0.618^{* * *} \\
(0.093)\end{array}$ \\
\hline Controls & No & Yes & No & Yes \\
\hline LGA fixed effects & No & No & No & No \\
\hline Observations & 82 & 66 & 82 & 66 \\
\hline $\mathrm{R}^{2}$ & 0.043 & 0.125 & 0.012 & 0.226 \\
\hline
\end{tabular}

An additional way to measure the extent to which markets face state threats is to look at the type of land the market is on. In general, markets on public land 
face greater threats from the government. Traders in these markets typically pay rent to the local government, and the local government has more rights to intervene in market affairs.

In table 4.5 I again subset the data to focus on strong market associations. We see suggestive evidence that is consistent with the theory's predictions for these markets. Strong market associations on public land are more likely to facilitate information sharing about dishonest customers compared to strong market associations on private land. Though the coefficient on land type is not always statistically significant, the fact that it is not negative is surprising, as existing research would suggest that private order would thrive on private land.

Table 4.5: For markets with strong associations, being in a market on public land is associated with the association being more likely to facilitate information sharing about dishonest customers. Controls include market ethnic diversity, and the education level of traders in the market. The data is subsetted to markets where I have interviews from 3 or more traders. The data do not include a small number of markets on federal government land. Due to the small $\mathrm{N}$ of this subsetted dataset, it is not possible to incorporate local government fixed effects here.

\begin{tabular}{lcccc}
\hline \hline & \multicolumn{4}{c}{ Dependent variable: } \\
\cline { 2 - 5 } & \multicolumn{2}{c}{ Honest accounting } & \multicolumn{2}{c}{ Info sharing } \\
& $>0.5$ on strength index & $>0.5$ on strength index \\
& $(1)$ & $(2)$ & $(3)$ & $(4)$ \\
\hline Land type (public = 1, private $=0)$ & 0.0003 & 0.036 & $0.115^{*}$ & 0.085 \\
& $(0.054)$ & $(0.056)$ & $(0.064)$ & $(0.064)$ \\
Constant & $0.788^{* * *}$ & $0.846^{* * *}$ & $0.464^{* * *}$ & $0.579^{* * *}$ \\
& $(0.041)$ & $(0.066)$ & $(0.048)$ & $(0.077)$ \\
\hline Controls & No & Yes & No & Yes \\
LGA fixed effects & No & No & No & No \\
Observations & 83 & 81 & 83 & 81 \\
$\mathrm{R}^{2}$ & 0.00000 & 0.073 & 0.038 & 0.148 \\
\hline \hline Note: & & & $*$ & $*$ \\
\end{tabular}


You might be concerned that public and private markets are different in ways that could be affecting market institutions. Table 4.1 showed that markets on private land are more likely to be ethnically homogenous that public land markets, but existing theories would suggest that would increase the likelihood of order, and I control for market heterogeneity in the regressions presented above.

The data suggest that markets on public land are more likely to have leaders who hold their positions for life, and existing research would posit that leader time horizon, not the nature of state threats, would be driving the outcome. Later in this chapter I will introduce evidence that a long time horizon is not sufficient for order, but for the moment it is difficult to disentangle these variables.

A final concern is that perhaps private order is more likely on public land markets not because of threats of state interference, but because public markets are selling higher-end products or have more desirable locations, and the gains to pro-trade institutions are therefore greater. This type of argument is functionalist, but as a proxy for these two variables we can compare shop rent across public and private land markets. Table 4.6 shows that rent is about $15 \%$ higher in private land markets.

Table 4.6: Mean annual rent. This table uses data from the 2015 survey.

\begin{tabular}{lccc}
\hline & Public & Private & $\mathrm{p}$-value \\
\hline Mean annual rent (USD) & $\$ 1,710$ & $\$ 1,964$ & $0.04^{* *}$ \\
$\mathrm{~N}$ & 222 & 469 & \\
\hline Note: & ${ }^{*} \mathrm{p}<0.1 ;{ }^{* *} \mathrm{p}<0.05 ;{ }^{* * *} \mathrm{p}<0.01$
\end{tabular}

The theory predicts an interaction effect between market association strength, state interference, and pro-trade institutions. While I do not observe data that is strongly inconsistent with this, when running models that interact association strength and local government interventionism, the interaction coefficient is rarely significant. 
The implication is that the survey data support predictions of the theory for strong market associations, but is not consistent with predictions for weak market associations.

One interpretation of this is that there are different types of weak associations. An association can be weak and largely absent, or weak but still making some effort to extort from traders.

\subsubsection{Mechanism: Markets that are more politically engaged are better governed}

The mechanism through which state threats promote good governance is that associations need the support of traders to fend off these threats. If the association extorts, it will not be able to mobilize traders for political ends, such as to vote as a block. One implication of this argument is that politically active markets should be better governed. After all, politicians will have little interest in associations that cannot mobilize traders to vote as a block.

Table 4.7 looks at the relationship between my two measures of market association political engagement, and association good governance. Markets that are more politically engaged - whether measured by the association providing traders information about politicians, or politicians coming to the market - are better governed.

\subsubsection{Mechanism: Market outcomes are better in markets that have had lawsuits}

The mechanism through which mutual strength results in private good governance is mutual threats. Here I compare institutions in markets that have and have not experienced recent lawsuits with the local government. A lawsuit, a visible strug-

gle between a group and the state, is a clear indication of mutual strength as it is costly for both sides. Lawsuits capture not just market association strength, but also 
Table 4.7: Markets that are more politically engaged - whether measured by the association providing traders information about politicians, or politicians coming to the market - are better governed. Controls include market ethnic heterogeneity, whether the market leader holds her position for life, and the education level of traders in the market.

\begin{tabular}{|c|c|c|c|c|}
\hline & \multicolumn{4}{|c|}{ Dependent variable: } \\
\hline & \multicolumn{4}{|c|}{ Market association good governance index } \\
\hline & $(1)$ & $(2)$ & (3) & $(4)$ \\
\hline Assoc. provides info about politicians & $\begin{array}{c}0.115^{* * *} \\
(0.038)\end{array}$ & $\begin{array}{l}0.077^{*} \\
(0.041)\end{array}$ & & \\
\hline Politicians come to market & & & $\begin{array}{l}0.063^{*} \\
(0.038)\end{array}$ & $\begin{array}{c}0.052 \\
(0.040)\end{array}$ \\
\hline Constant & $\begin{array}{c}0.465^{* * *} \\
(0.024)\end{array}$ & $\begin{array}{c}0.484^{* * *} \\
(0.034)\end{array}$ & $\begin{array}{c}0.492^{* * *} \\
(0.023)\end{array}$ & $\begin{array}{c}0.505^{* * *} \\
(0.034)\end{array}$ \\
\hline Controls & No & Yes & No & Yes \\
\hline Observations & 195 & 171 & 192 & 168 \\
\hline $\mathrm{R}^{2}$ & 0.045 & 0.031 & 0.014 & 0.017 \\
\hline
\end{tabular}

market association ability to mobilize traders, as the presence of a lawsuit means the market has raised the necessary funds from traders. What this analysis tests, then, is whether struggles and disputes between a market and interventionist local government are associated with disorder, which conventional wisdom would expect, or order, as my argument predicts.

Table 4.8 shows that traders in markets that have had lawsuits score higher on the market association good governance index. While the relationship is not statistically significant when restricting the sample to associations with observations from three or more respondents, the coefficient remains positive and large.

What if, though, very strong market associations discourage local governments from entering into a lawsuit? Were this the case, there would not be a balance of 
Table 4.8: Markets that have had lawsuits with local government - evidence of mutual strength - score higher on the association good governance index. Controls include market ethnic heterogeneity, whether the market leader was elected, and the education level of traders in the market. Columns 3 and 4 look at associations that three or more traders surveyed belonged to.

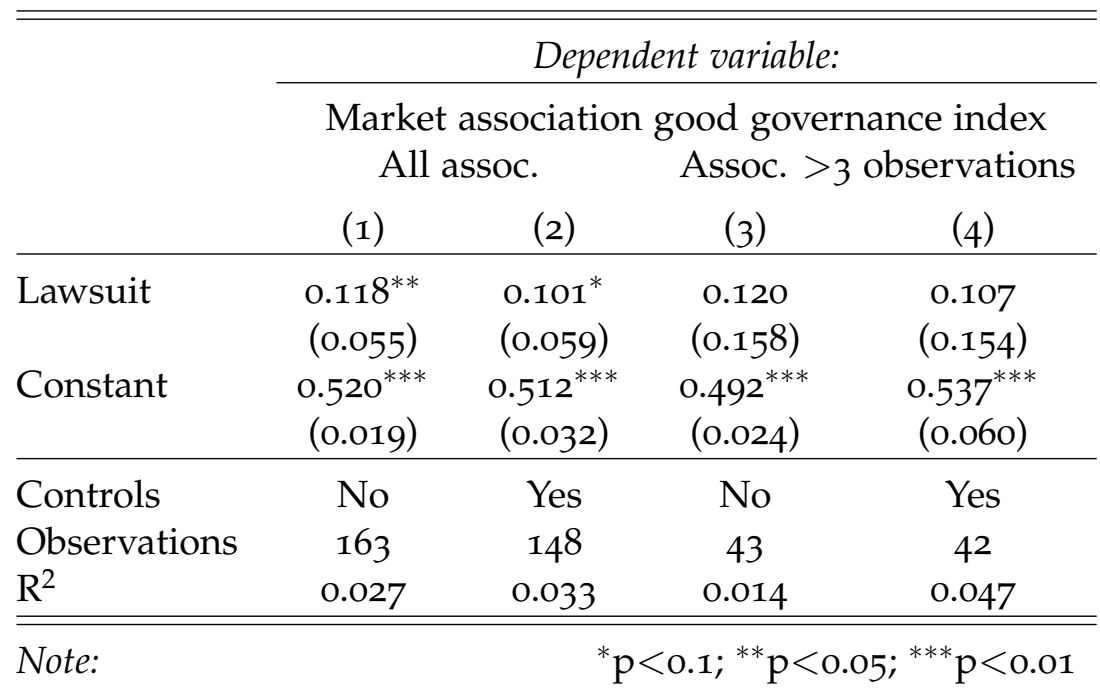

power. But empirically, this is not a concern. Some of the strongest Lagos markets, such as Trade Fair, an Igbo market with ties to high-level Igbo leaders throughout Nigeria, has had a lawsuit with the local government where it is based.

\subsection{Assessing additional factors that may shape private governance}

In this section I will empirically assess the additional factors laid out in in chapter 1 that could shape the outcome. 


\subsubsection{Other group-level explanations}

\section{Market sorting is difficult and rare}

If an association is extorting heavily from group members, why wouldn't the members relocate to another group? Wouldn't this constrain extortion? This would seem to be especially true in the case at hand: traders' shops are quite small, and a trader could pack all of her wares into a taxi in one hour at most. Capital mobility should provide group members with more bargaining power vis a vis their leaders (Bates and Lien, 1985).

In chapter 1 I argued that group member sorting - i.e. members identifying orderly groups and choosing to join those - should be difficult and rare. Here I look at the evidence.

First, as noted in chapter 3, market membership is sticky. Shop owners require two years rent up front from traders, which is the norm in Lagos (and many other West African cities) for residential leases as well. After these first two years, traders can pay the following one year's rent up front, which deters relocation, as a new lease would require two years rent up front. I calculate that two years of advance rent is N701,279 $(\$ 2,910)$ for the average trader, which is a substantial amount of money. ${ }^{1}$ When asked how difficult it would be to move to another market, $66 \%$ of traders who responded said it would be difficult or very difficult. ${ }^{2}$ If you include the respondents who said they did not know, which suggests they had never even considered moving, this figure rises to $73 \% .^{3}$ As further evidence of the difficulty of moving, the average

\footnotetext{
${ }^{1}$ Data from the trader survey conducted in 2015.

2 This question was only asked in the public market survey.

3 The 2013 survey asked traders "Imagine you wanted to relocated your shop to a different local government market, how difficult would this be?" and "Imagine you wanted to relocated your shop to a market that was on private land, how difficult would this be?" These summary statistics average
} 
trader has been in her market or plaza for 7 years. ${ }^{4}$

It may be difficult to relocate, but can traders sort into pro-trade markets in the first place? Table 4.2 shows that while many traders were attracted to their plaza because it had a reputation for being a place where goods sold quickly, many traders made the decision about where to locate based on reasons that do not require knowing much about whether or not the market was conducive to trade. $10 \%$ of traders report being attracted to their plaza only because of its desirable location. This category encompasses reasons such as the market being in a busy area, close to the trader's home, and close to the trader's suppliers. $9 \%$ of traders report being attracted to their plaza only because the product they sell was sold in the plaza.

I argue this is at least partly due to imperfect information about internal market affairs. Even diligent traders will struggle to get reliable information about conditions in a market. One trader tries to do her own survey of traders before renting a shop. "But most times, even if the the market is bad, they won't tell her," her son said. "And if they know she wants to sell similar goods, they would even hoard information from her." 5

It does, however, appear to be the case that traders stay longer in markets that are better governed. Table 4.9 shows that traders in markets that score highest on the good governance index (1) stay in their market on average three years more than traders in markets that score the lowest on the good governance index (o). It is striking, however, that traders in the worst governed markets stay on average for five years. This suggests that, at minimum, relocation is not frictionless.

responses across these two questions.

4 Data from 2015 survey.

5 Interview with the son of a trader in Mile 12 market on June 13, 2016 


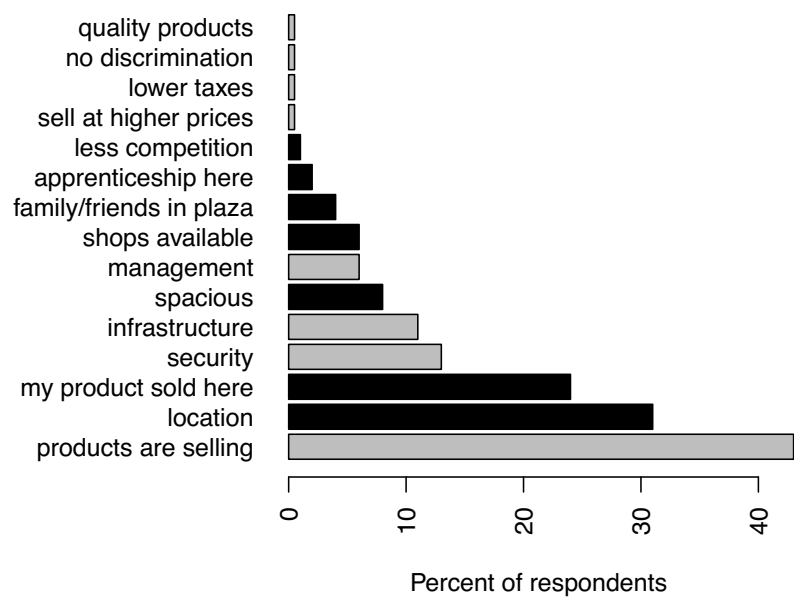

Figure 4.2: Traders choose to locate in markets for many reasons, several of which do not require knowing if the market is conducive to trade. This figure shows responses to the question: "What attracted you to this plaza?" This was an open response question that was then coded. Grey bars are reasons that could be related to market conditions. Black bars are reasons that are not about market conditions. Data is from a pilot for the 2015 survey $(\mathrm{N}=196)$.

\section{Sanctioning leaders is difficult and mutiny is rare}

Why do traders not sanction or overthrow predatory market leaders? Empirically, mutiny appears to be rare. In the 68 markets surveyed in 2013, only three of the markets had had a market leader overthrown in the past ten years.

The existing literature posits that predatory behavior should be constrained when group leaders are socially embedded in the group. In urban contexts, however, this embeddedness is rare. In the 2013 survey traders were asked if other traders in the market attended the same church or mosque that the respondent attended. $30 \%$ of traders said no one from their market attended the same church or mosque. Indeed $61 \%$ of traders live in a different local government than the one they trade in. 
Table 4.9: Better market governance is correlated with more time in market. Predicted values for average number of years traders have been trading in a market based on the market association's good governance index score. These data come from the 2015 survey.

\begin{tabular}{rr}
\hline Good governance index score & Years in market \\
\hline 0 & 5.11 \\
0.5 & 6.69 \\
1 & 8.26 \\
\hline
\end{tabular}

There is often an assumption that in groups where there is social embeddedness there will also be more trust within the group. The data show, however, that if you report going to the same church of mosque as other traders, you are $12 \%$ less likely to share information about opportunistic suppliers with other traders. I do not propose a theory for why this might be, but I think at minimum the role of competition in affecting cooperation within a group is often ignored and can trump other factors.

Mixed evidence on the relationship between leader time horizon and private order institutions

A subset of markets in Lagos have leaders who are (mostly) elected, and then hold their position for life. In table 4.10 I compare market association good governance across markets where leaders hold their position for life and markets where leaders have terms and term limits. I find that markets with leaders who hold their position for life are more likely to facilitate information sharing about dishonest customers, but are no more likely to account honestly for fees or score higher on the good governance index overall. Why might this be?

I proposed earlier one factor that could mediate the relationship between a long time horizon and private predation: whether the group leader has outside business interests. Early data from the second round of 2015 survey suggest that 14 associations (our of 141 associations represented so far) have leaders with other businesses, 
and many of these businesses are substantial. One market leaders sells cars. Another works as a clearing agent at the port. Another market leader owns gas stations.

External factors may also affect how a leader perceives her time horizon. In the context of Lagos markets, electrical fires in markets can destroy a market overnight. These fires are not uncommon. One market is gutted by a fire approximately every month. Theorists might argue that a leader with a long time horizon should invest in better wiring for the market, but many threats are out of the leader's control. A neighboring market could have a fire that spreads. Some fires are cause by oil tankers that spill on the road.

Table 4.10: Market associations with leaders who hold their position for life are more likely to facilitate information sharing among traders, but are no more likely to account honestly for fees or score higher on the good governance index overall. Controls include market ethnic heterogeneity, and the average education level of traders in the market. All models look at the subsetted data that exclude markets with data from less than three traders.

\begin{tabular}{lcccccc}
\hline \hline & \multicolumn{7}{c}{ Dependent variable: } \\
\cline { 2 - 7 } & \multicolumn{7}{c}{ Honest accounting } & \multicolumn{2}{c}{ Info sharing } & \multicolumn{2}{c}{ Private governance index } \\
& $(1)$ & $(2)$ & $(3)$ & $(4)$ & $(5)$ & $(6)$ \\
\hline Leader for life & 0.011 & 0.027 & $0.205^{* * *}$ & $0.174^{* *}$ & 0.002 & -0.002 \\
& $(0.045)$ & $(0.056)$ & $(0.056)$ & $(0.070)$ & $(0.025)$ & $(0.031)$ \\
Constant & $0.796^{* * *}$ & $0.792^{* * *}$ & $0.395^{* * *}$ & $0.457^{* * *}$ & $0.528^{* * *}$ & $0.561^{* * *}$ \\
& $(0.029)$ & $(0.064)$ & $(0.036)$ & $(0.080)$ & $(0.016)$ & $(0.036)$ \\
\hline Controls & No & Yes & No & Yes & No & Yes \\
LGA fixed effects & No & No & No & No & No & No \\
Observations & 98 & 96 & 98 & 96 & 98 & 96 \\
$\mathrm{R}^{2}$ & 0.001 & 0.004 & 0.121 & 0.137 & 0.00004 & 0.012 \\
\hline \hline \multirow{2}{*}{ Note: } & \multicolumn{7}{c}{${ }^{*} \mathrm{p}<<0.1 ;{ }^{* *} \mathrm{p}<0.05 ;{ }^{* * *} \mathrm{p}<0.01$}
\end{tabular}


I measure ethnic diversity by creating an ethnolinguistic fracationalization score for associations. (Higher scores means the association is more diverse.) These scores are based on the ethnicity of surveyed traders. As such, I subset the associations to those that I have data from three or more traders. In table 4.11, I find that there is no relationship between association ethnic diversity and association good governance. This does not change when controlling for the type of land the market is on and whether the market leader was elected.

Table 4.11: More ethnically homogeneous markets are not better governed than diverse markets. Controls include whether the market leader was elected and the type of land the market is on.

\begin{tabular}{lcc}
\hline \hline & \multicolumn{2}{c}{ Dependent variable: } \\
\cline { 2 - 3 } & \multicolumn{2}{c}{ Market association good governance index } \\
& $(1)$ & $(2)$ \\
\hline Market association ethnic heterogeneity & -0.078 & -0.030 \\
& $(0.116)$ & $(0.109)$ \\
Constant & $0.505^{* * *}$ & 0.148 \\
& $(0.036)$ & $(0.091)$ \\
\hline Controls & No & Yes \\
Observations & 50 & 50 \\
$\mathrm{R}^{2}$ & 0.009 & 0.311 \\
\hline \hline Note: & & ${ }^{*} \mathrm{p}<0.1 ;{ }^{* *} \mathrm{p}<0.05 ;{ }^{* * *} \mathrm{p}<0.01$
\end{tabular}

This is not to say that traders themselves do not attribute cooperation to ethnic homogeneity. The head of the Oke-Arin market association attributes the ability of the market association to elicit information about opportunistic outsiders to the fact that, "We are Igbo. We share experiences with each other."6 But there are many

\footnotetext{
${ }^{6}$ Interview with Oke-Arin market leader on January 28, 2015.
} 
markets - such as the spare parts market - that are ethnically homogenous but lack these practices.

\subsubsection{Individual-level explanations}

No relationship between supplier coethnicity and credit

In chapter 1 I proposed that shared ethnicity may not increase cooperation in transactions in Lagos markets because the mechanism that is typically found to connect shared ethnicity with cooperation is held constant in this context, namely the finadability of traders. Here I look at the data.

In the 2013 survey traders were asked about the ethnicity of their main supplier, and whether they had received products on credit from their main supplier in the past six months. I find no statistical difference in the ability to access products on credit for traders whose main supplier is a coethnic or non-coethnic.

Table 4.12: Traders are not more likely to report receiving products on credit from their main supplier in the past six months when their main supplier is a co-ethnic.

\begin{tabular}{lccc}
\hline & Coethnic supplier & Non-coethnic supplier & $\mathrm{p}$-value \\
\hline Credit & 0.41 & 0.37 & 0.37 \\
$\mathrm{~N}$ & 261 & 438 & \\
\hline Note: & & ${ }^{*} \mathrm{p}<0.1 ;{ }^{* *} \mathrm{p}<0.05 ;{ }^{* * *} \mathrm{p}<0.01$
\end{tabular}

Relational contracting cannot substitute for private order institutions

Relational contracting depends on the ability of individuals to build reputations. I expected that, in developing countries, structural conditions would make this more difficult than previously assumed. Using transaction-level data from the 2015 survey I look at the relationship between the length of time individuals have know a supplier 
and whether a transaction resulted in receiving a product with any defects. Table 4.13 shows that when traders have known their supplier for a longer period of time they are less likely to receive products with defects, but the coefficient on relationship length is exceptionally small.

Table 4.13: There is a negative but small relationship between the length of time a trader has known their supplier and whether products they received had any defects. The second model controls for the total cost of the purchase.

\begin{tabular}{lcc}
\hline \hline & \multicolumn{2}{c}{ Dependent variable: } \\
\cline { 2 - 3 } & \multicolumn{2}{c}{ Products have defects } \\
& $(1)$ & $(2)$ \\
\hline Length of relationship with suppliers & $-0.001^{* *}$ & $-0.002^{*}$ \\
& $(0.001)$ & $(0.001)$ \\
Constant & $0.047^{* * *}$ & $-0.134^{*}$ \\
& $(0.005)$ & $(0.073)$ \\
\hline Controls & No & Yes \\
Trader fixed effects & No & Yes \\
Observations & 3,627 & 2,866 \\
$\mathrm{R}^{2}$ & 0.001 & 0.003 \\
\hline \hline Note: & ${ }^{*} \mathrm{p}<0.1 ;{ }^{* *} \mathrm{p}<0.05 ;{ }^{* * *} \mathrm{p}<0.01$
\end{tabular}

There is evidence that supports the assertion that it is difficult to develop a reputation. In the second round of the 2015 survey, which is ongoing, $(67 \%$ of sampled traders have been surveyed, $\mathrm{N}=532$ ), traders were asked "When you are cheated by a dubious supplier outside Nigeria, who do you tell?"7 Enumerators read out eight options, including traders in your market, traders in a different market, family, etc. $49 \%(\mathrm{~N}=259)$ of traders reported that they told no one. Of those who chose "other," $(\mathrm{N}=23), 7$ reported telling God or Jesus.

\footnotetext{
7 We did not ask about domestic suppliers.
} 
This logic of keeping information secret is not specific to overseas suppliers. When asked “When you are cheated by a dubious customer in Lagos, who do you tell?" 34\% of traders reported that they told no one.

\subsubsection{Other explanations that emphasize public institutions}

There is variation in market order within local governments

I proposed in section 1.2.3 that variation in the quality of the public legal institutional environment should not affect private group order. The first point to make is that while local government good governance is improving in Lagos, local governments are still widely perceived as corrupt. Figure 4.3 uses data from the 2013 survey. Traders were asked what the most important thing the local government had done for the markets was, and $60 \%$ said nothing.

A second point to make is that there is great variation in the quality of market association governance within local governments. Figure 4.4 looks at data from the 2015 survey. $25 \%$ of the associations represented in this survey were in Ojo local government, and this figure shows the distribution of market association representativeness scores across the associations in this local government. In six of the markets, $100 \%$ of traders said the association represents their interests. In five of the markets, $100 \%$ of traders said the association does not represent their interests. ${ }^{8}$

\footnotetext{
${ }^{8}$ A more direct way to test the role of public institutional quality would be to regress market association good governance scores on measures of local government good governance. I was not able, however, to identify a trustworthy measure of local government good governance. I coded state government financial audits of the local governments, and even indicators within the audit reports were not be correlated with each other. Nor were audit measures correlated with indicators from the Lagos State Household Survey that asked residents about their perceptions of their local governments. Based on my own interviews in many local government secretariats, I perceived one local government to be particularly well-governed, yet this local government received one of the worst overall scores on the two financial audits I coded. Given these constraints - be they measurement or conceptual - assessing within-local government variation in market association good governance seems to be the best test of this argument.
} 


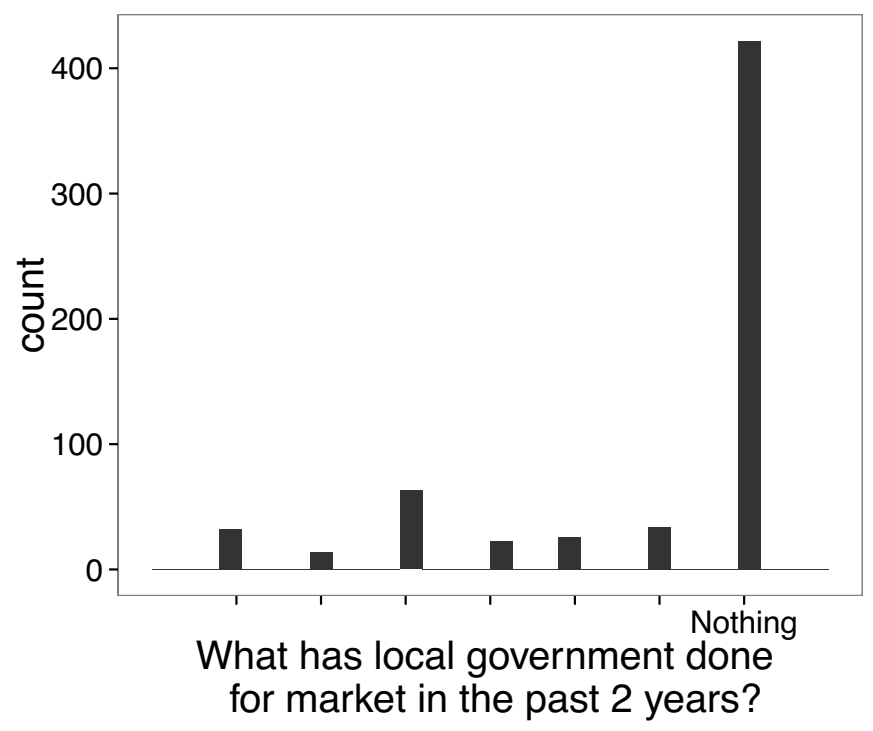

Figure 4.3: Traders do not perceive local governments as representative. In the 2013 trader survey traders were asked about the two most important things the local government has done for the market. $60 \%$ of traders $(\mathrm{N}=422)$ said nothing. Other responses included things like improving access to water and drainage.

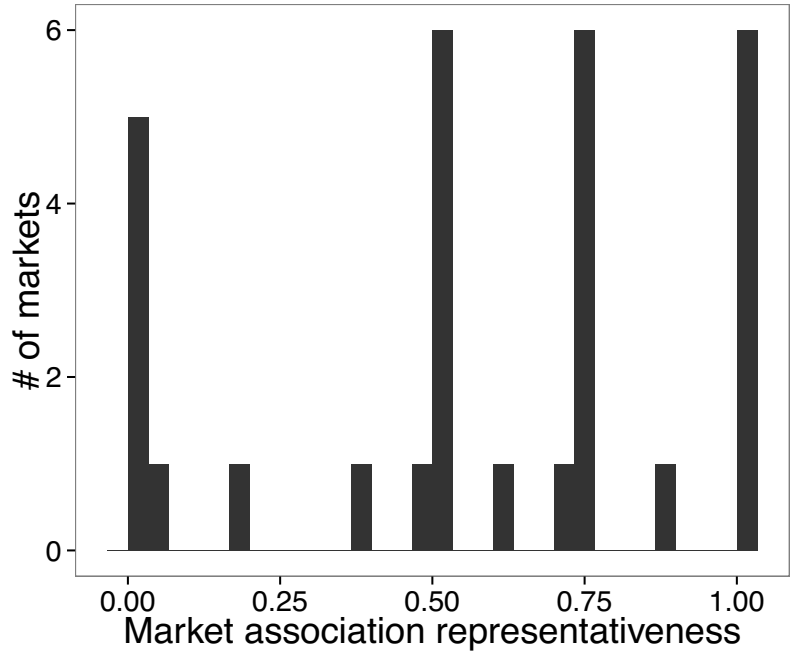

Figure 4.4: There is variation in market association representativeness within local governments. This figure shows the distribution of market association representativeness scores across markets within Ojo local government. 


\section{Markets with imposed leaders not in better-run local governments}

Earlier I raised the possibility - as suggested in literature on private order among traders in medieval Europe - that associations that seem private might actually be more public than they appear. This is not necessarily an alternative explanation, but if true it would call into question whether the outcome variable - private order - is what I propose it is. One manifestation of this possibility in the context of this study is that perhaps these seemingly private Lagos market associations are in fact appointed by government. I collected data in the 2013 survey on whether the local government played a role in the selection of the market leader. In five of the sixty-eight markets the modal trader said the market leader was imposed on the market.

Perhaps the fairest test of the argument that public officials appoint impartial private leaders to promote trade and increase tax revenue (Edwards and Ogilvie, 2012) would be to assess the dispute resolution effectiveness of the local governments that these markets are situated in. If these markets are in local governments that are highly effective at resolving disputes, that would be consistent with a motive of increasing the size of the pie. Using data from the trader survey and the Lagos State Household Survey, table 4.14 shows that in contrast to the benevolent and trade-promoting public judges at the Champagne Fairs, markets where the local government influenced market leader selection are no more or less likely to be in local governments with higher conflict resolution effectiveness.

\subsection{Conclusion}

The extant body of scholarship on private governance is largely 1) theoretical, and 2) based on case studies of groups that have private ordering institutions, ignoring groups that are failing or have failed. In this chapter I looked at individual, trans- 
Table 4.14: Markets where the local government (LGA) influenced market leadership selection are not more likely to be in local governments with high conflict resolution abilities.

\begin{tabular}{lccc}
\hline & Markets, no LGA meddling & Markets, LGA meddling & p-value \\
\hline LGA confl. res. eff. & 0.37 & 0.38 & 0.89 \\
$\mathrm{~N}$ & 62 & 5 & \\
\hline Note: & & ${ }^{*} \mathrm{p}<0.1 ;{ }^{* *} \mathrm{p}<0.05 ;{ }^{* * *} \mathrm{p}<0.01$
\end{tabular}

action, and association-level data from two surveys covering traders in markets with different types of institutions. This allowed me to test theories about the conditions that make pro-trade institutions more or less likely.

I am of course not the first to conduct surveys of small businesses in Africa. Existing surveys, however, such as the World Bank's Enterprise Surveys, rarely ask questions about market associations. These associations, though, are critical to understanding trade-related outcomes. 


\section{TESTING THE THEORY WITH THE MARKET MEN AND WOMEN ASSOCIATION}

\begin{tabular}{|c|c|c|}
\hline \multirow{4}{*}{ Strong assoc. } & Interventionist government & Non-interventionist government \\
\hline & Market Men and Women Association & \\
\hline & Argument predicts: Order & \\
\hline & Observed: Order & \\
\hline & & \\
\hline
\end{tabular}

\subsection{Introduction}

Arms-length, impersonal trade can exist even in contexts where the state does not protect property or enforce contracts. We observe institutions such as informal remittance systems in South Asia (Schaeffer, 2008). In America prison gangs enable contractual transactions for illegal drugs (Skarbek, 2014). Private groups can police the behavior of their members by punishing opportunistic actions, they can incentivize information-sharing about unreliable traders outside of the group, and organize boycotts of those who cheat group members. These enforcement and information sharing institutions can secure property rights when traders cannot rely on impartial formal legal institutions. The efficiency gains these groups can secure, however, do not guarantee that such groups will emerge.

The argument I have made, in short, is that private order will be most likely when 
an association is strong - by which I mean able to control the internal affairs of the group - and the state interventionist - meaning motivated to intervene in organized societal groups, typically to extract revenue. Under these conditions the group and state can credibly threaten the other; the group can make electoral threats and the state can threaten either the income or ownership rights of the group members. Each side has an incentive to bargain and to fulfill commitments.

Here I consider the balance of power argument in the context of the Market Men and Women Association (MMWA), an umbrella group for the markets in Lagos state. I present an analytic narrative to assess the foundations of order in this single important case, tracing the "behavior of particular actors, [clarifying] sequences, [describing] structures, and [exploring] patterns of interaction" (Bates, 1998, 10). The outcomes of interest will be three particular components of order: state extortion, private extortion, and the presence of trade-promoting institutions.

I begin by documenting private order within the MMWA. In particular, I focus on the MMWA's ability to limit a special type of public extortion, "agent predation" predation by the "bureaucratic periphery" (Markus, 2015, 2). I then present evidence consistent with the balance of power argument: the MMWA is strong, Lagos state is a paragon of an interventionist government, and there is evidence of one of the mechanisms, namely the MMWA's ability to mobilize market associations and their traders. I then look at the origins of the MMWA and trace the group's history throughout the 2oth century. Doing so, I show that the Market Men and Women Association has been strong for about a century, thus assuaging concerns of endogeneity.

I conclude by addressing an obvious alternative explanation, that what I call a balance of power is in fact state collusion. I bring a variety of evidence to bear on this question, and conclude that the MMWA remains independent of the state. While 
the true independent power of the Market Men and Women Association is difficult to observe because the power balance is so effective that off the equilibrium path events have been exceptionally rare in recent years, we can observe compromises that emerge from this balance of power, and I discuss one such compromise in detail.

\subsection{Market Men and Women Association order}

According to the argument, with a balance of power group members will experience less public and private extortion, and the group will be more likely to have private institutions that support contractual trade.

Indeed, this is what we see within the MMWA. One component of extortion is unpredictability of tax collection. As will be expanded on in section 5.5.1, state taxation of traders is very predictable - if traders simply pay an annual flat rate they are considered tax compliant. There are no surprise visits by tax officials to markets. In fact, traders go themselves to mini Lagos State Internal Revenue Service offices to pay their taxes.

Private taxation in this context are the dues that traders pay to the MMWA. These dues, called market development levies, are collected by individual market associations and passed up to the MMWA. They are regular, and traders across markets pay the same amount.

Finally, consistent with the argument, there is strong evidence of trade-promoting institutions within the MMWA. The MMWA provides dispute resolution services, handling arguments that cannot be resolved at the market level, or disputes that take place across markets. ${ }^{1}$ As one example, recently textile traders who customized their textile designs overseas were threatened by Nigerian traders who copied these de-

\footnotetext{
${ }^{1}$ Interview with Market Men and Woman official, April 19, 2013
} 
signs and had them reproduced in China. The MMWA blacklisted these traders such that no one within the MMWA would do business with them, and informed the government about these traders, who were potentially violating a patent law. ${ }^{2}$ As another example of costly trade-promoting institutions, the MMWA allows outside suppliers to come to MMWA meetings to collect money from traders who have defaulted on payment agreements. ${ }^{3}$

\subsubsection{How state-MMWA cooperative activities mitigate agent predation}

In this section I assess a specific type of public extortion, namely "agent predation." Agent predation involves threats to income or ownership rights from low-level bureaucrats who cannot be controlled by politicians Markus (2015). Here agent predation is conceptualized as local government predation. I discuss how the Market Men and Women Association empowers individual markets to push back against this predation. MMWA effectiveness here is offered as further evidence that the MMWA is "orderly," successfully promoting trade for group members.

The roots of state government interest in promoting local government accountability

Bola Tinubu, currently the informal head of the APC, won gubernatorial elections in Lagos state in 1998. He quickly established himself as someone who aimed to shake things up - he alienated party elders by appointing technocrats to head state ministries (de Gramont, 2014). His relationship with then-president Olusegun Obasanjo quickly became contentious as he vied for increased autonomy for Lagos state. Efforts to increase the number of local governments in Lagos became the most

\footnotetext{
${ }^{2}$ Interview with Lagos state government official, January 22, 2015

3 Interview with non-market based agent at MMWA secretariat on April 19, 2013
} 
salient dispute with the federal government, and ultimately Tinubu created 37 new local governments without federal permission. Still today, these 37 local governments are not formally recognized by the federal government.

Challenging the federal government required - and still requires today - strong local popular support and substantial internally generated revenue so as to not be so dependent on the federal government's monthly oil revenue allocations. Tinubu and his successor Babatunde Fashola worked aggressively to increase the quality of management of local governments in Lagos, a strategy that furthers both the goal of increasing popular support and internally generated revenue. Ensuring that the local government was responsive to societal interests has been seen as an important strategy for maintaining popular support for the APC and increasing the ability of local governments to collect fees and taxes.

The APC has taken a series of steps to increase local government accountability and effectiveness. Tinubu created the Office of State Auditor General which conducts financial audits of local governments and publishes critical assessments of financial management. In the 2011 audit, 22 of 57 local governments were labeled as not having their financial books in order - a binary measure. The local government chairmen who perform worst on these audits are called to testify before the Lagos State House of Assembly and might lose APC support in running for subsequent terms in office. The APC has employed carrots in addition to these sticks. The commissioners who headed state ministries often got their jobs by first proving themselves as effective local government chairmen. Total APC dominance in the state has allowed Tinubu to nominate chairmen candidates who he thought would be effective managers and not worry so much about selecting someone who had the best prospects electorally. 4

\footnotetext{
4 There have been some exceptions to this. APC discretion is constrained particularly when strong
} 
GRAPH INDICATING THE LEVEL OF EACH STATE'S FINANCIAL DEPENDENCE ON FEDERAL ALLOCATION (IN \% TERMS) - 2008

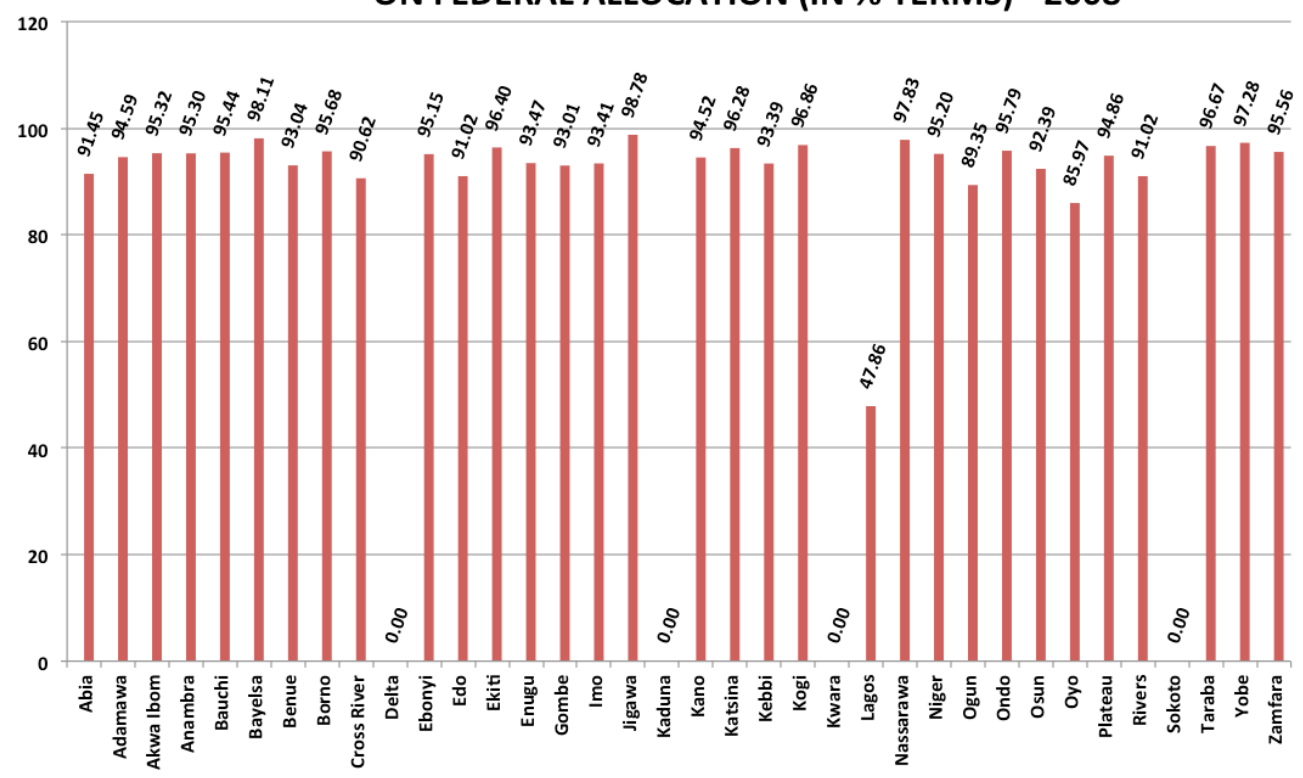

Note: Data not available in respect of Delta, Kaduna, Kwara and Sokoto States Source of Data: Joint Tax Board

A presentation by The Executive Chairman

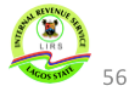

Figure 5.1: Lagos state has had recent success in decreasing dependency on federal allocations by increasing internally generated revenue. This image is a slide from a Lagos Internal Revenue Service presentation. Lagos' self-sufficiency is not due solely to the fact that it is the largest commercial area in the country. It is only over the past decade that the state has effectively increased internally generated revenue. From 2005 to 2014 internally generated revenue increased from 35 billion Naira to 245 billion Naira, a 700\% increase (Awam, 2014).

While the APC's efforts to improve local government accountability might seem unusual given the party's dominance in Lagos state, a large literature describes how authoritarian regimes exhibit responsiveness to citizens (e.g. Malesky and Schuler, 2010; Tsai, 2007; Weeks, 2008). More specifically, Meng, Pan, and Yang have shown that in China, a similarly non-electorally competitive, single party context, state offi-

traditional families predominate in a local government. 
cials evaluate local officials based in part on how responsive they are to citizen complaints (2014). Greif has observed that in medieval Europe, "'securing property rights from the grabbing hand of the state' was achieved through "merchant guilds" that shared information about [property rights] abuses, coordinated retaliatory responses, and held the sovereigns in check" (Markus 2015, 10 citing Greif 2006, 91).

\section{How the MMWA helps market associations check local government abuses}

The Market Men and Women Association, its interests aligned with the state government in the goal of limiting local government abuses, helps to further this objective. A state government official said that a principal goal of the MMWA's weekly meetings is to encourage market leaders to "compare notes. What are you enjoying in your local government that I'm not?'5 Though MMWA meetings are organized wholly by the association, state government officials often attend and encourage market leaders to acquire information that empowers them vis a vis local governments.

The MMWA provides other services to empower markets to check local government power that are not always aligned with state government interests. Many local governments are in the process of demolishing and re-building markets throughout the state. This is a strategy with strong state support. The state government has a "modernizing" mission, of which new markets that look like Western shopping plazas fit in well. Further, local governments usually award a contract to a developer to rebuild markets in exchange for the right of the developer to collect rent from traders for a set period of time. These contracts provide local governments with huge short-term boosts to internally generated revenue, a critical metric on which the APC evaluates local government chairmen. Renovating markets often improves safety as

\footnotetext{
5 Interview on January 22, 2015
} 
well. New markets usually have better lighting, and developers will destroy areas where thugs have historically congregated, furthering both state and local government interest in promoting security.

But market traders often vehemently oppose to these plans to create modern markets. A trader selling yams on a wooden table would almost certainly be priced out of a new market that only had lock-up shops. Further, rebuilding markets can take a long time, and even if traders were somehow able to afford a shop in the new market, they would be without a place to sell for months if not years. The MMWA helps to broker compromises. It helps market associations negotiate with developers to guarantee traders below-market rates for buying or renting shops in the new markets. It helps traders negotiate with the local government to find a temporary location where traders can sell while the market is being rebuilt. ${ }^{6}$

In addition to facilitating information sharing about local government policies and helping markets negotiate with local governments about market renovations, the MMWA also helps markets deal with another way in which local governments violate property rights, namely local government implicit encouragement of hawker presence. Traders who sell products without licenses, usually on the streets, take away business from market traders. Fashola made considerable efforts to remove hawkers, passing a law that explicitly banned them and creating the Kick Against Indiscipline (KAI) brigade to enforce this law. Yet local governments often permit hawkers to trade in their communities in exchange for illicit payments, a clear violation of property rights (Holland, 2014; Markus, 2015). The Market Men and Women Association serves as a channel through which markets can convey hawker problems to state agencies. A market leader might have trouble getting the attention of the

\footnotetext{
${ }^{6}$ Interview with Lagos state government official on January 22, 2015
} 
Ministry of Environment, the Lagos State Marketing Board, or KAI on her own, but if she brings the complaint to the MMWA, the MMWA will use their connections to ensure the problem gets the attention it needs. ${ }^{7}$

\subsection{The balance of power between the Market Men and Women Association and the Lagos state government}

In this section I first assess the extent of recent state government interventionism, finding that the state has repeatedly intervened in and negotiated with organized groups in society. I then assess the strength of the MMWA. Next I consider the MMWA's political power - the mechanism through which the balance of power would constrain state extortion. I find that the association is strong and has the ability to make credible political threats against the state government.

\subsubsection{Evidence of state interventionism}

In an attempt to separate state interventionism from societal power, I have defined an interventionist state as one with politicians who aim to intervene in locally salient private groups, either to extract money or to transform the group. Interventionist states are typically interventionist in an organized fashion, able to enter into credible negotiations with organized societal groups.

The Lagos state government has proven repeatedly that it is able to credibly bargain with societal groups. Efforts to reform public transport is one clear example. To reduce traffic, former governor Bola Tinubu launched a plan in 2004 to introduce high-capacity buses, some with their own dedicated bus lanes (de Gramont, 2014). This policy was expected to see huge opposition from the drivers of Lagos' 75,000

\footnotetext{
7 Interview with market developer on January 12, 2014
} 
small and mid-sized buses, most of whom operate under the very powerful National Union of Road Transport Workers (NURTW) (Lagos Urban Transport Project Implementation Completion and Results Report, 2011). The prospect of NURTW opposition was crippling; banks were reluctant to finance the purchase of these buses without evidence that the NURTW was on board (de Gramont, 2014, 74). Further, the APC did not want to risk losing the NURTW's political support. Tinubu and his successor Fashola invested in long, difficult, and creative negotiations with the union. Union officials were sent on trips to Latin America to see how bus lanes worked there (de Gramont, 2015). A union-affiliated cooperative was given the rights to operate the bus lanes. After more than five years of bargaining with the NURTW, the state government finally introduced the high capacity buses in $2007,{ }^{8}$ and the dedicated bus lanes in 2008.9

Public transport reform is just one example of the state government's recent efforts to negotiate with and intervene in organized societal groups. Another example is the strengthening of the Lagos Internal Revenue Service (LIRS) and LIRS negotiations with Lagos business associations to increase tax compliance, discussed further in section 5.5.1. The state government has also negotiated with groups of area boys, or thugs, and brought them off the streets by employing them into new state agencies including the Lagos State Traffic Management Authority (de Gramont, 2015). While this example might seem to be a case of state weakness - shouldn't a government be able to remove people from the streets who are engaged in illegal behavior without offering anything in return? - the organizational power of the area boys presented a formidable obstacle. The state government's ability to remove them through negotia-

\footnotetext{
${ }^{8}$ lagbus.com.ng

9 'Voices of Confusion on Lagos BRT Buses.' Daily Trust. 22 July 2008.
} 
tions is evidence of its interventionism.

\subsubsection{Evidence of MMWA strength}

There are a variety of ways to measure the strength of a group, and on all measures the MMWA scores highly. One way to measure MMWA strength is to look at the association's ability to communicate with traders. Effective communication is a necessary condition for control. When I look for evidence of communication, I find that the MMWA holds weekly meetings for market leaders at its headquarters. These meetings last several hours, and take place in the traffic-clogged state government secretariat neighborhood. For many market leaders attending these meetings is a full-day commitment. Yet these meetings are exceptionally well-attended. Only rarely, when the traffic is very bad, will some market leaders from the far outskirts of the city miss a MMWA meeting. ${ }^{10}$

\subsubsection{Evidence of MMWA mobilization ability}

Association strength is used to promote trade when the association needs the support of traders to be able to mobilize them against state threats. In this section I consider whether we see evidence of such mobilization.

According to my argument, in a balance of power equilibrium protest should be rare. Threats of protest should be credible, and mutually beneficial negotiations should be possible without the need to actually protest. For this reason it is difficult to observe directly whether the MMWA has the ability to collectively mobilize in protest against the state. What we can observe, however, are cases of the MMWA mobilizing collectively for other reasons. There have been several cases of the MMWA

\footnotetext{
${ }^{10}$ Interview with Lagos state government official on January 22, 2015
} 
requesting that all markets close down to mark the death of a notable person. When Abibat Mogaji, the long-time head of the MMWA died in June 2013, the MMWA ordered markets to close in Lagos for two days, and evidence suggests compliance was high. Newspaper articles and online forums ${ }^{11}$ quote individuals frustrated by their inability to buy or sell products. ${ }^{12}$ This Day reported that, "all major markets in the Lagos metropolis including Odo, the ever-busy Balogun market, Ilepo market in Iyana Ipaja, Aswani, Agege, Mile 12, Boundary, Mosafejo Suru-Alaba, Ajegunle, Ikotun, Ladipo market in Mushin, Oyingbo market in the Mainland, and the Ikeja market, among others, were shut in compliance with the directive. Even markets where spare parts are sold like the Trade Fair market were all shut down yesterday."

\subsection{Attributes of modern Lagos state did not cause MMWA strength: Tracing the organizational strength of the Lagos market women from the early 1900 s}

This section documents that the Lagos market traders association has been strong since the early 1900s, assuaging concerns that the strength of their association is a function of attributes of modern Lagos state.

\subsubsection{Antagonism between the market women and colonial administration}

Though the Lagos market women would occasionally organize themselves to address particular issues - such as to protest a water tax in 1908 (Johnson, 1982) - the origins of the Market Men and Women Association (MMWA) as an organization are more accurately traced back to the 1920s, when Madam Alimotu Pelewura, a fish trader, became head of Ereko Market, a prominent meat market on Lagos Island.

\footnotetext{
${ }^{11}$ nairaland.com/1328649/lagos-markets-closed-abibat-mogajis

12 thisdaylive.com/articles/mogaji-when-honouring-the-dead-inflicts-pain-on-the-living/150853/
} 
Pelewura led the market with actions that now resemble nascent forms of the strategies the MMWA uses so effectively today: she could shut down the markets to signal the market women's strength, and she collected three pence per week from traders, funds which were used to pay lawyers and clerks who served as intermediaries, translators, and letter-writers for interactions with colonial officials (Johnson, 1982). Pelewura led a market association that effectively communicated with, negotiated with, and pushed back against the colonial state.

Pelewura and the market women had a strong relationship with Herbert MacCaulay, an early nationalist leader who founded Nigeria's first political party, the Nigerian National Democratic Party (NNDP), in 1923. MacCauley spoke with the market women in Yoruba and showed respect toward their traditional leaders and Islamic associations (Johnson, 1978). He recognized Pelewura's popularity, and helped her to create the Lagos Market Women's Guild (Johnson 1978), foreshadowing a strong tradition of Lagos politicians allying with market leaders who had popular, grassroots support. The Guild would prove to be the financial backbone of the NNDP from the 1920 to the 1940 (Sklar, 2004).

While MacCaulay effectively collaborated with the Guild, the colonial administration saw the market women organization, and in particular the efficiently run Ereko Market, as a threat. Some colonial officials advocated that the market association provide more of a social function, and not collect fees and perform internal sanctioning functions (Johnson, 1978). But even social functions were not without controversy. When Pelewura was planning to close the markets so that the traders could perform a play, colonial officials tried to argue that Pelewura did not have the right to shut down the markets. The colonial administration correctly perceived Pelewura's strength as a threat, but her ability to mobilize traders was merely one manifestation 
of this strength, not a root cause. In any case, Pelewura simply responded that she could not guarantee she would not close the markets (Johnson, 1978).

In the 1930 Pelewura, serving as representative of sixteen markets, was appointed to the local Ilu committee, a committee of representatives of societal groups that reported to the $o b a$, or traditional king. While Nigerian politicians continued to work with the powerful market women, the colonial administration repeatedly proposed policies that alienated them. Pelewura successfully fought off colonial attempts to relocate Ereko market - a threat markets face even to this day, as "modernizing" state officials work to put traders into physically delimited areas for trading and allocate property in space-constrained Lagos.

In 1932 rumors circulated that the colonial administration planned to start taxing the Lagos market women. The market women met to discuss this, and sent representatives to colonial officials, who quickly assured them there was no truth to these rumors. In the late 1930s, however, in an effort to raise funds for World War II, the administration did indeed try to start taxing the women - in particular, women who made more than fifty pounds per year. By this point Pelewura was the clear head of the Lagos market women, and she led the fight against this tax.

In 1940, under the leadership of the iyalode (among the highest Yoruba traditional titles given to women) Rabiatu Alaso Oke and Pelewura, market women protested at the colonial commissioner office, arguing 1) that it went against local custom to tax women, 2) that unlike British women, who paid taxes, African women were poor, and 3) that the women had no vote in Lagos, and thus should not be asked to pay taxes. Traditional rulers in Lagos strongly supported the women's protest. When the commissioner disregarded their demands, the market women closed the markets. Closing the markets - a remarkable sign of strength - would become a strategy to 
credibly signal the strength of the association to the state. The protest largely succeeded. Bernard Henry Bourdillon, the governor at the time who was on close terms with the early nationalist leaders, agreed to tax only women who made more than 200 pounds per year, which was a very small portion of traders (Johnson, 1982).

The market women again effectively exercised their strength in fighting price controls. In 1939, at the start of World War II, a variety of factors, including men moving to the cities leading to less farm labor, contributed to a food shortage. In 1941 the colonial administration introduced the Pullen marketing scheme, an attempt to implement price controls for food products. Throughout the early 1940s Pelewura led the fight against the price controls, utilizing new strategies along with old strategies that had served her well in dealing with previous challenges. The first-order response was to simply not abide by the scheme, and the colonial administration was largely unable to enforce their policies. In October 1943 the colonial administration took a new approach, buying up large quantities of food and selling them at a set price, essentially subsidizing transport and other costs. In response the Lagos market women physically disrupted the trucks transporting this food and convinced producers to sell to the traders as opposed to government officials (Oyemakinde, 1973). Pelwura employed the strong support of MacCaulay, his NNDP, and the traditional rulers of Lagos. She threatened to shut down the markets. At one meeting with colonial officials Captain A. P. Pullen (the marketing scheme's namesake) tried to buy off Pelewura, offering her a monthly salary of more than seven pounds if she would assist in the price scheme implementation. She refused (Johnson, 1982).

Pelewura went on to secure a compromise on gari (a way of eating cassava), perhaps the most contentious issue under the price control. Pullen offered to remove gari price controls, but in return, Pelewura had to guarantee that the price of gari 
would be kept relatively low. Pelewura followed through on this promise, and resisted internal pressure to raise the price of gari.

The price scheme remained on the books until 1947, but it was rarely implemented effectively, with black markets flourishing throughout the city (Oyemakinde, 1973). In 1944 about two-thirds of Lagosians were buying food on the black market (Lindsay, 1999).

\subsubsection{The relationship between traders and early nationalist leaders}

The Guild remained strong after MacCaulay's death in 1946, transferring their support to the new oba of Lagos, Adeniji Adele II, and a coalition of the NCNC, NNDP, and Nigerian Labour Congress. Indeed, by backing both, they helped them win seats in the 1950 Lagos Town Council elections (Folami, 1982).

In 1958, two years before independence, the nascent Action Group, threatened by NCNC electoral success, began attempting to incorporate the markets into their party structure. Six market supervisors set up party structures inside markets (Sklar, 2004, 436). At this time, decisions were being made to transform two areas of Lagos Island into markets. While traders were working to understand the stall allocation process, the Town Council began to realize it had vastly underestimated the cost of making these low-lying areas suitable for trade. With the Town Council cash-strapped, the Action Group saw an opportunity. It began working in concert with the Lagos Town Council to make stall allocation conditional on Action Group membership (Rapson, 1959). The confusion about the allocation process and fees concerned the traders, presenting the first test of whether the market women could organize themselves in the absence of Pelewura, who had died in 1951.

In November 1958 the market women petitioned the governor through the NCNC 
and United Muslim Party to express their concern about (among other things) the politically-driven allocation of market stalls. The NCNC petition stated:

[...] for some time now, the most irregular thing has been happening in the Council. When the new Nylon Market was opened at Ereko, inspired by the Action Group, some women constituted themselves the custodian of the market and started to collect market dues from others. The strangest thing was that only women who pay through those women are guaranteed markets. And before any woman can be entered down for market allocation, she must in the first instance, enroll as a member of the Action Group and receive an Action Group Membership Card. What that has to do with market allocation beats our understanding (Rapson, 1959).

The petition went on to describe how the Town Council had admitted to receiving funds from this group of AG-allied women to delegate stall allocation. When the market women approached the Town Council Chairman about the matter, he feigned ignorance of the situation. The petition concluded that 'Markets should never be made the subject matter of political propaganda but that is the way of the Action Group-controlled Lagos Town Council' (Rapson, 1959).

In a report finalizing an inquiry into the matter, $\mathrm{R}$. N. Rapson, one of the colonial administrators, tried to find a middle ground. He wrote:

The petition from the N.C.N.C. stated that the Action Group were 'playing politics with the allocation of markets in Lagos.' I am of the opinion that this remark slightly over-states the case, but I consider Mr. Oshodi [an AG employee and also the 'secretary' of the AG women who were attempting to allocate stalls] did take full advantage of his dual position of working for the market leaders and the Action Group and obtained many additional members for his party. In this he was ably assisted by some market leaders who are also Action Group supporters (1959, 20).

Rapson ordered the system of stall allocation be returned to one that did not 
privilege any group, a win for the market women, but he did not order a substantial amount of funds refunded to the women.

The inquiry - the existence of the thorough, lengthy, and detailed investigation itself - was a sort of acknowledgement of the strength of the market women. At this time almost all of the traders belonged to one association - and the remainder belonged to no association, as opposed to a competing association (Rapson, 1959). The Town Clerk was holding productive meetings with the leaders of the market women (Rapson, 1959), evidence of the need to acknowledge their power.

Despite the controversy surrounding the AG's political mobilization of the market women, the party had the support of the market women after independence which helped them win the 1962 Lagos Town Council elections (Peil, 1991, 64). By 1964 the AG had party branches in all the main Lagos markets (Baker, 1974).

\subsubsection{The Lagos Market Women Association during a period of political instability}

In 1966 Nigeria experienced the first of what would become an extended series of military coups. The first period of military rule, which lasted until 1979, was disorganized. The military quickly dissolved the Lagos City Council, and put in place a new committee where 1 of the 25 seats would be reserved for a representative from the market women (Baker 1975). Temporary splits within the market women emerged as several groups of market women competed for the seat. The military ultimately picked a market leader from Tejuoso Market, Modupe Caxton-Martins, to fill the seat, but she conspicuously lacked representation on any of the Council committees most relevant to the markets (Gafari, 1996).

M. O. Gafari, a Nigerian scholar who wrote about the Lagos Market Women Association during this period, noted "the official omission of the Association from the 
committee making decision on markets" (1996, 75-76). Multiple divisions within the Lagos City Council (the Lagos Town Council's successor) had authority to manage and regulate the markets, leading to confusion over jurisdictional responsibility. Lagos City Council leadership lacked the political will to initiate pro-market policies. Without any organized threats from the state, the market association was not sufficiently incentivized to proactively promote pro-trade conditions. This is not to say the market women were no longer powerful. Their latent strength was made visible during occasional, and occasionally successful, petitions to the State Governor to advocate for minor infrastructural improvements and the removal of certain fees (Gafari, 1996). But the period of military rule was not one of great achievements for the Lagos Market Women Association.

\subsubsection{The emergence of the modern Market Men and Women Association}

Abibat Mogaji became leader of the Lagos Market Women Association from the 1980s, but was active in the association prior to this. She had a series of critical successes. A main success was in disrupting the dominance of European importers and Syrian and Lebanese wholesalers and retailers. In the 1960s Europeans controlled most of the importing. They had warehouses on Lagos Island, and in Apapa, near the port. Lebanese and Indians dominated one layer of the textile and provisions wholesale trade. Nigerians would buy wholesale from these wholesalers and re-sell to hawkers and street vendors (Mabogunje, 1964). Mogaji 'rallied Nigerians to tap into the lucrative retail trade in Lagos Island that was exclusively dominated by Greek and Lebanese merchants. She effectively mobilised indigenous traders and funded a few of them directly to ensure a level-playing field and halted the monopoly by 
Caucasians in her own country.'13

Mogaji's son, Ashiwaju Ahmed Bola Tinubu, would become the governor of Lagos following the return to democracy in 1999. But the market association, now called the Market Men and Women Association, would remain both independent and strong. Following Mogaji's death in 2013, her granddaughter, Bola Tinubu's daughter, Folashade Tinubu-Ojo, became the new Iya Loga General for Lagos. (Iya loga means mother of the market, and "general" connotes being the mother of multiple markets.) The process by which Tinubu-Ojo became the new Iya Loga General is unclear, but it is evident Bola Tinubu's All Progressives Congress party had been grooming Tiubu-Ojo to succeed her grandmother, as she had been serving as head of the Lagos Market Development Board and was thus known to the market traders. The Peoples Democratic Party (PDP), which controls the presidency but is in opposition in Lagos state, protested Tinubu-Ojo's appointment, citing it as evidence of what they claimed were the dictatorial tendencies of Babatunde Fashola, Lagos' governor at the time. ${ }^{14}$

This section has illustrated the strength of the Lagos market women association historically. The colonial state repeatedly attempted to co-opt the market leaders, and the market leaders repeatedly resisted, focusing instead on serving the interests of the group members. The strength of the traders' association has manifested itself frequently over the past century, with the market women bringing their preferred politicians to power and mobilizing traders to shut down markets when the need to protest arises.

\footnotetext{
13 allafrica.com/stories/201306240736.html

14 Interview with Lagos state PDP officials on July 1, 2013
} 


\subsection{Evidence contrary to presence of state-MMWA collusion}

A skeptic might describe the relationship between the Market Men and Women Association and the Lagos state government as one of collusion. After all, since the start of the 4th Republic in 1999 the MMWA's leader has been either the mother of Bola Tinubu (through 2013) or Tinubu's daughter (2013-today). The current MMWA head also heads the Lagos State Market Development Board, and it is not possible to point to a single instance of the MMWA vocally protesting against the state government on any issue in the past 15 years.

But the MMWA is not colluding with the state government. First, Bola Tinubu became governor in part due to the grassroots support of traders that his mother had. It is not the case that his mother became head of the MMWA because of Tinubu's political base. Second, in the literature on collusion in single-party regimes the goal of collusion is often acquiring support for the government from organized societal groups (Gandhi and Lust-Okar, 2009; Haber, 2006). When the group is an opposition party and the party leader is bought off in exchange for securing regime support, clearly that is collusion. But when a societal group has a set of interests that, ex ante, align with the interests of the state, evidence of cooperation does not imply collusion. In the case of the MMWA, support for the state government does not imply collusion.

Third, suggestive evidence for the independence of the MMWA comes from the fact that individual market associations pay the MMWA for recognition. When Sangrousse market, a traditional market on Lagos Island, split into two markets, New Sandgrousse market paid 100,00o Naira (\$414.94) for the "coronation" of the new market mother, and the same amount for the recognition of the new market father. When costs for ceremonial entertainment were included, the price tag for MMWA association recognition for the new market came to 400,000 Naira $(\$ 1,660)$. The MMWA 
asked for additional money for recognition of an assistant market mother and assistant market father, but the market declined. ${ }^{15}$ If the MMWA was truly colluding with the state government, it is unlikely a traditional market would be willing to pay such a large amount of money just for the association's recognition. ${ }^{16}$

Finally, as of 2015 only markets on public land belong to the MMWA. ${ }^{17}$ The state government is working on a policy that would require markets on private land to register with the state government. Practically, this would mean these markets would have to meet an assortment of safety and hygeine regulations, such as having a certain number of toilets. If this policy goes through, the leaders of the private markets have expressed their desire to join the MMWA. The plaza leaders perceive the MMWA as a potential channel for making their needs known to government. Given that markets need to pay substantial amounts of money to join the MMWA, the fact that private markets would want to join strongly suggests that when state-MMWA interests diverge the MMWA does not simply toe the government line.

\subsubsection{Meaningful compromises as evidence of the absence of collusion}

The ability of the MMWA and the state to credibly threaten the other leads to mutually beneficial and meaningful compromises, an observable implication of a balance of power. With a true balance of power, these compromises are reached before implicit threats become explicit. Without such a balance of power, agreements can theoretically be reached, but often they must involve simultaneous exchange and

\footnotetext{
15 Interview with trader at New Sandgrousse market on August 15, 2013

${ }^{16}$ I acknowledge that in a wholly corporatist system one might also observe groups paying an umbrella association for membership, as that might be the only way to access state benefits. This evidence, then, does not provide unequivocal support for the argument.

17 There are a handful of exemptions: not all public markets belong to the MMWA, and some markets on private land do belong to the MMWA.
} 
the scope of agreements that include such exchange are limited. The disarmament payment a post-conflict government provides to former rebels on receipt of a single weapon is an example of such simultaneous exchange; formal representation in exchange for demobilization would be preferable to both sides, but the commitments that would be required for this by each side are often not able to be made credible with an imbalance of power, usually favoring the victorious party.

Given that the MMWA is strong and the state interventionist, substantial compromises should be observed, and indeed that is what we see. Here I describe one compromise: negotiated tax rates during the Fashola administration.

Tinubu created the Lagos Internal Revenue Service as governor, and under Fashola LIRS has been made increasingly independent (de Gramont, 2014). The head of LIRS reports directly to the governor. LIRS has been a tool for the state government to accomplish the critical goal of becoming increasingly financially independent of the federal government. Given the visibility and perceived importance of Lagos' "informal" sector, targeting this sector was a priority. Not surprisingly, informal sector traders had concerns about this when the idea was first introduced. The MMWA's key victory can be observed in the tax rate they negotiated with LIRS. They negotiated an annual flat rate of 2,500 Naira (about US\$10.37) per year for most traders. This is exceptionally low. On average traders pay three times as much for the local government trade permit rate, the main local government tax, and some local governments have additional fees they levy on traders. ${ }^{18}$ Indeed LIRS acknowledges that at the moment LIRS is losing money on informal sector tax collection. ${ }^{19}$

LIRS, however, has seen several successes in these negotiations as well. Though

\footnotetext{
18 Analysis of 2013 survey data. This excludes traders who said they did not pay the trade permit rate. For these traders, the rate is often included in rent.

19 Interview with LIRS officials on October 23, 2012
} 
they are losing money on informal sector taxation, the APC's first-order goal is getting informal traders on the tax roll. In 2014400 of the 1,000 staff in the LIRS' Department of Special Duties were solely responsible for increasing informal sector compliance (de Gramont, 2014). LIRS has achieved relatively high levels of compliance. The 2013 survey data indicate that $48 \%$ of traders pay state taxes, ${ }^{20}$ and market leaders provide LIRS with lists of traders along with information about who is and is not paying (de Gramont, 2014). Today, LIRS says of all the sectors they interact with, the informal sector is the most compliant. ${ }^{21}$ Additionally, 40 markets have consented to have mini LIRS offices inside their markets. It is impressive that so many markets consented to this, as it gives the government a much better sense of the volume of trade taking place in the markets, information that could be used down the line to increase tax rates. In summary, LIRS/MMWA negotiations on taxation are a clear example of a mutually beneficial compromise being reached: the MMWA won a low tax rate and the state government won high compliance.

\subsection{Conclusion}

In this chapter I argued that the Market Men and Women Association is a group that promotes contractual economic exchange and works to protect the property rights of its members, and I presented suggestive evidence that this outcome is consistent with my argument for understanding group order. I showed that the MMWA has been strong for over a century, assuaging concerns that is is currently strong

\footnotetext{
20 To mitigate problems of social desirability bias, traders were asked whether they had a Lagos state taxpayer ID card, not whether they paid state taxes. Additionally, to 'create a perception of equal social legitimacy' (Samii, 2013, 6) I prefaced the question with the phrase 'I know that for many traders it is too difficult to get the Lagos State tax ID card.'

${ }^{21}$ Interview with LIRS officials on October 23, 2012
} 
because of attributes of the Lagos state government today.

Markus argues that when business associations are created by the state, the state either co-opts the association or creates the association so as to tie their own hands and give firms the power to organize collectively (2015). The history of the Market Men and Women Association suggests an alternative explanation for political involvement in a business association: early nationalist leaders in Nigeria encouraged the organization of market traders to create a group that would be able to enter into mutually beneficial arrangements with politicians - namely the exchange of political support for state policy that would represent the interests of traders. Ultimately the outcome was that politicians had tied their hands by bolstering the traders' organization, but this does not seem to have been the intent.

But what are "the interests of traders?" Do the interests of the traders who belong to the Market Men and Women Association overlap with the interests of traders who do not belong to the group, or the interests of society more broadly? In a recent review of research on Medieval guilds, Ogilvie offers a pessimistic conclusion: guilds "[secure] rents for guild members [...] then [transfer] a share of these rents to political elites in return for granting and enforcing the legal privileges that enabled guilds to engage in rent extraction" (2014). In this view, guilds not only do not benefit nongroup members, but impede general economic growth. Successful trading locations in Medieval Europe, Ogilvie argues, emerged with improvements in public security, not guild-based privileges.

On the most direct level, the MMWA sounds much like these guilds. Baker has observed that historically the MMWA has acted, "as a pressure group only when their vital interests are directly at stake. They have not agitated, for example, for lower taxes, better education, or increased public medical facilities, issues one might 
expect to be of special concern to them" (1974, 242). The MMWA negotiates for predictable and fair taxation specifically for its group members. They negotiate to cushion traders who might be dislocated by market renovations. These are certainly not public goods.

And yet, there are trickle-down effects of MMWA order that promotes economic growth for non-group members. To the extent that the MMWA promotes order at the market level, non-group consumers and retailers will be more likely to be able to buy products on credit in markets under the MMWA. Suppliers of traders in MMWA member markets will be willing to provide products on credit, as the prospect of repayment will be high. These contractual transactions are welfare enhancing for all parties, not just traders in MMWA markets. 


\section{CONCLUSION}

\subsection{The myth of spontaneous order}

Existing research on private governance focuses on groups that are characterized by sophisticated private ordering institutions. Scholars focus on describing the private

order institutions, and detailing precisely how these institutions promote trade (e.g. Stringham, 2015). Much of this body of work is functionalist, arguing that successful private groups will emerge to fill gaps in the public provision of social order. In fact, such groups are exceptional. Unsuccessful groups abound, they simply do not attract the attention of scholars. Nor do failing groups support the ideological leanings of the free market institutes - such as the Mercatus Center at George Mason University - that fund much of the work on private governance.

What results is a "myth of spontaneous order" (Bretherton, 2014), when in fact there are enormous hurdles to the provision of private order institutions. Groups leaders must be able to elicit information about dishonest traders, information that will be hard to come by in competitive business environments when traders may benefit from other traders being cheated. Further, something must check the power of group leaders who could otherwise extort.

Lagos markets are an ideal context to assess the conditions that make private good governance more likely. Lagos state has hundreds of markets spread across dozens of local governments, but the nature of traders' access to courts and police is held 
constant, as these are state and national institutions. Additionally, because a subset of these markets are on land that is designated for markets, I can see failing markets hold for much longer they might in other contexts.

In this project we saw that some markets are governed by associations that promote trade within the market. These associations often collect information about dishonest customers and suppliers, obtaining this information by helping traders resolve disputes. These associations then share this information among all of the traders so that opportunistic business partners can be avoided. These associations impartially resolve disputes, whether it is a dispute between traders in the market or a dispute between a trader and outside individual. Neutral dispute resolution services sometimes go against the short-term interests of group members, but these associations push ahead, and the result is an environment where a wide variety of individuals feel comfortable conducting business. Meanwhile, other markets are governed by associations that extort from their own members.

The results of this study affirm existing research showing that groups can enable economic exchange in contexts where the public institutional environment does not protect property rights. Indeed institutions in successful market associations in Lagos look remarkably similar to institutions in trading groups in medieval Europe (Greif, 2006) and prison gangs in America (Skarbek, 2014). But I have argued that the fact that group members would benefit from private pro-trade institutions does not explain their existence. I have introduced an argument about the conditions under which group associations will invest in these institutions to promote trade. When the government keeps its hands off the economy, group leaders extort. When the government threatens to intervene, leaders organize to resist. 


\subsection{Summary of argument and findings}

While much attention has been devoted to the consequences of self-enforcing internal group dynamics that protect property rights and enable contractual trade, this dissertation has focused on the politics that sustain these institutions. I have argued that when a government and a group can each credibly threaten the other, group order is more likely. Mutual threats lead to order for two reasons. First, an association needs internal support to keep threats credible, deterring predation by group leaders. Second, a strong association is motivated to police the behavior of members to limit intervention from meddling public officials.

The argument, counter-intuitively, is that even when predatory politicians work directly against the interest of traders, they unintentionally generate the private institutions that benefit the traders. I contribute to a literature that has found support for this surprising path to growth in other places and times. Looking at the emergence of credit markets in medieval England and colonial Uganda, Duggan found that "[i]ronically, the naissance of the formal credit sector was, largely, the result of the state's systematically disempowering lenders, rather than of powerful individuals making efforts to protect their capital" (Forthcoming).

The main finding is that among strong associations, those that face state threats are more likely to privately provide order. State threats can take many forms, but the threats I focused on here were being in an interventionist local government or on local government land. The survey data provide evidence consistent with a mechanism of associations needing trader support to mobilize against the state, and the case studies provide evidence that associations may invest in pro-trade institutions to reduce the likelihood that disputes attract state attention. The relationship, however, is not deterministic. One of the market case studies suggests that in rare instances 
collusion can occur, leading strong associations to predate jointly with interventionist local governments.

I empirically assessed a variety of additional factors that have been theorized to shape private order. First, I addressed an intuitive possibility: perhaps traders sort into trade-promoting markets. The implication would be in line with conventional wisdom that markets that are not conducive to trade would not attract traders. I found that, as might be expected, traders stay in well-governed markets slightly longer than badly governed markets. But I document a series of frictions that make relocating difficult, and the result is that even traders in badly governed markets stay for a while: on average traders stay in the worst governed markets for over five years. And there are challenges to sorting into trade-promoting markets in the first place: with survey data and the case studies I documented the hurdles to acquiring accurate information about market conditions. Another intuitive possibility was that when market leaders hold their position for life their incentives are aligned with incentives of the other traders, and this leads leaders to not extort and to invest in trade-promoting institutions. Using the survey data, I found that indeed when market leaders hold their position for life they are more likely to facilitate information sharing among traders. But they are no less likely to extort. A long time horizon is not sufficient for private order.

I considered explanations that individual-level dynamics should obviate the need for group-level institutions. Looking at data from thousands of transactions, I found that longer relationships with suppliers do not substantially reduce the likelihood of receiving products on credit. I also found no relationship between sharing an ethnic identity with a supplier and receiving products from the supplier on credit.

Then I considered explanations that emphasize the public institutional environ- 
ment. I found that attributes of the local government alone cannot explain variation in market association good governance. I documented wide variation in the quality of private governance within local governments. I also show that while there may be variation in the quality of governance across Lagos' 57 local governments, for the most part traders perceive local governments as corrupt and ineffective. The notion of a well-governed local government somehow improving private governance is unlikely in this context.

Finally, I expanded the scope of observation, testing the theory on the Market Men and Women Association, the umbrella group for markets in Lagos state. I found evidence that this association promotes trade among its member markets, and that MMWA trade-promoting institutions can be explained by the balance of power argument.

\subsection{Broader implications}

The most precise way to discuss the bounds of the argument is to say that it applies in contexts where the rule of law is weak but not absent. When laws are impartially and efficiently enforced, private associations are less critical. The activities they might undertake - impartial dispute resolution, for example - are less needed, as the presence of a neutral legal system backstops individual cooperation. Yet in the absence of any even partially formed legal system, state threats will be disorganized, and I do not expect disorganized state threats to motivate private order institutions.

The argument may extend to accounts of private policing in $19^{\text {th }}$ century California, where private police forces were developed as a response to predatory public police (Stringham, 2015). The argument may apply to claim clubs, informal governments of squatters on frontier land in the $19^{\text {th }}$ century American West. These informal 
governments existed in the face of severe threats from the government, namely state efforts to sell this publicly-owned land (Murtazashvili, 2013). The argument could shed light on informal minibus associations in Jamaica, where there is some member communication "[t]o reduce the incursion of the police on their activities" (Cervero and Golub, 2011, 508).

The current view that predominates of private governance - namely that if it is needed, it will emerge - leads to detrimental policies. In developing country contexts the policy implication would be for the state to keep its hands off the economy. Special economic zones that are in some ways outside the purview of the state are one example of this. Yet the data presented in this project suggest that in the absence of the threat of state interference, private leaders may extort. Through an antagonistic process of interchange, ineffective public officials may be effective in a generative way. This is not too suggest that the state should impose leaders on private groups, but the notion of an absentee state as promoting private good governance is misguided. Working within the structures of an organized state might be preferable - even if the organized state is predatory.

How does private group order shape the broader economy? There are some reasons to be pessimistic about the externalities of group order. As discussed in chapter 5 , research on medieval guilds suggests that guilds not only did not benefit non-group members, but impeded general economic growth by buying privileges from political elites that tilted the playing field (Ogilvie, 2014). But in the absence of strong rule of law, it is not clear that generalized economic growth is the counterfactual (North, Wallis and Weingast, 2009). Further, the beneficiaries of group order are many. In developing countries it is estimated that $41 \%$ of GDP comes from the informal sector (Schneider, 2005), and the associational structure of informal trade is a global 
phenomenon (e.g. Cross, 1998). Future research on the externalities of group order should consider questions such as whether a group lobbies for club goods or public goods, and whether the outcome of interest is growth or equitable growth.

This research has shed light on the inner workings of modern informal economies and introduced conditions under which we will observe pro-growth institutions in associations that govern informal trade, associations that encompass a vast amount of global economic output. 
APPENDIX

134 


\section{A. APPENDIX TO CHAPTER I}

Below is a list of associations represented in the 2013 and 2015 trader surveys.

15A Oremeji Street Plaza Association 34 Egbeda Shop Owner Association 5 Oshitelu Street Complex Association 6 Ola Ayeni Street

8 Idowu Lane Plaza Association

AB Plaza Association

Abia Plaza Association

Abule Ado Plank

Adebayo Market

Adesina Market

Agbajowo

Ajah Ultra Modern Community

Ajina

Akrape market aka Fafunke

Alarape Market

Allied Shopping Plaza Association

Amalgamated Association

Anamabra Traders Association

Anola Oniru

Araromi.Ojo

Aroso Market

Asogbo Market

Associated Footwear \& Allied Product

Association of Progressive Traders

Association of Salon \& Hairstayles

Association of Weave-On Traders/Kawa Union

Atunrase Market Association

Auto Spare Parts \& Machinery Dealers Association

Bakky Plaza Association

Balogun Business Association

Balogun Ladies Dress Association

Balogun Traders Association

Bauchi Shoe \& Sandal Association

Benue Plaza Association

Bolashodun Plaza Association

Borno Cluster Association
19 Opebi Road Association

34 Plaza Market Association

5 Otigba Street Plaza Association

7 Idowu Lane Shopping Complex

8 Ola Ayeni Street Plaza Association

Abeni Plaza Association

Abuja Plaza Association

Abule Layeni Market

Adekunle Market

Afijalo Market

Agidingbi Market

Ajao Plaza Association

Akoberu II Market

Alakoro Market Association

Alasho Association

Amalgamated

Ampanda Phone Accessories Association

Anikantamo Plank Market Association

AO Trader Association

Araromi.Oshodi

Asade Market

Asokobowa Market

Association of Cosmetic \& Hair Product

Association of Ready-Made Clothing

Association of Shoe Manufacturer \& Dealers

Aswani Market

Audio Video Sellers Association of Nigeria

Baale Night Market

Balogun Bags (Hang Bags) Association

Balogun Childrens Wears Association

Balogun Shoe Association

Bauchi Cluster Association

Bayelsa Association

Block B11A Plaza Association

Bonbata

Breadfruit Traders Association 
Brother Club Association

C11 Plaza Traders Association

CD Marketers/Producers Association

Christian Association

Corner Stone Block B Association

Delta Plaza Cluster Association

Designer Plaza Union in Gbajumo

Diamond Plaza Association

Dosunmo - Estate of Adeniyi Brothers

Dosunmo, Alhaji Rufai Ajala House

Ebonyi Plaza Association

Egbeda Market

Ekiti Plaza Cluster Association

Electrical Dealers Association

Electro-Textile Market Association

Enugu Youth Association

Euro-Asia Plaza Association

Fajol Complex Committee

Fancy Traders Association

Fashion \& Tailoring Materials Association

Finished Textiles Association

FSP Market Daniel Strret

Gateway Market Association

Gbajumo Shoe Trader Union

George \& Lace Dealers Association

God is Able Plaza Association

Good Hope

GSM Plaza Association (Lagos Island)

GTB Plaza Association

H Plaza Landlord Association

Hausa Union Association

Ibukunoluwa Lace Association

Idowu Lane Association

Ifelodun Market Association

Ifelodun Phone Accessories Association

Igbehinadun

Igbo Union Association

Ijaiye Gutter Lace Association

Ikorodu North Central

Ilasamaja Market

Importers Association of Nigeria

International Market Association Electronics Sector

Iporin Market

Ise Oluwa Plaza Market Association

Italian Set Association, Balogun Market

Iya Loga Onigele

Jeunola

Kajawole (ISAWO)

Kano Market Plaza

Kebbi Plaza 1 Association
C\&S Plaza Association

Carlous Plaza Association

Cherub Mall Association

Computer \& Allied Products Dealers Assoc. of Nigeria

De-Line Market Association

Demurin Market

Destiny Plaza Traders Association

Doherty Traders Association

Dosunmo Ebun Eko Book Sellers Association

Dosunmo/Obun Eko Market Association

Ebute Ero Market Community Association

Ejegun Egba market

Eko Plaza Association

Electrical/Electronics Association

Emab Union Association

Ereko Balogun Market Association

F Line Traders Association

Fancy Furniture Dealers Association

Farce

Fashion Designer Assoc./Balogun Fashion Wear Assoc.

Francine Dealer Association

G Line Section Association

Gbajumo Market Association

GBO Market Association

Gift Marketing Alliance

God's Favour Plaza

Great Nigeria Plaza Traders Association

GSM Plaza Association (Victoria Island)

H Line Association

Haggai Plaza Association

HAWAN

Idera Market Association

Ifelodun Bristol Traders/Market Association

Ifelodun Market Council B/Stop

Igbehin-Adun Market Association

Igbo elerin Temidire

Igbo Union Association (Oniru)

Ijesha Market

Ikota Shopping Complex Association

Imo Plaza Association

Industrial Market Association

International Market Electrical Association (IMEA)

Iron Dealers Association

Iseoyemi

Itire Awope Plank Market

Jakande Estate Low cost Retail Market

Kaduna Traders Association

Kajola Maket

Katsina Plaza Clusters

Kitchen Utensil Association 
KK Ventures

Kuje Auwo Maza Maza Market

Ladipo market

Lagoon Plaza Women Association

Leather Association

Maboreje

Maja Plaza Association

Multipurpose Market Igando

Niger 2 Plaza Association

Obadina Plaza Association

Odo Eran Matori Market

Ogooluwa Market

Oja Oba Plaza Association

Ojo International Traders Centre

Ojuemure

Oke Odo Market

Oladipupo Plank Market

Olojo Drive Association

Oluwole Union Shopping Mall Association

One Love Association

Oniru Market Association

Onyeaghana Nwanneya

Orija

Oseni Market

Owode Market

Owolowo Textile Market Association

Paul \& Mike Association

Pelewura

Phone Dealer Association

Plastic Dealers Association

Powa Plaza Phase 1 Association

Prince Plaza Traders Committee

Progressive Auto \& Article Dealers Association

Queen's Plaza Association

Rivers Cluster Association

Saliu Aliu Market Association

Sangotedo Traders Association

Sebuff Plaza Association

Shoe \& Bag Association

St. Peter Ibidoja Association

Sura Shopping Plaza Association

Technical Association

Topaz Plaza Association

Turner Market

Union Home Association

United People Plaza Association

Unity Plaza Association

Victory Plaza Association

Wine \& Beverages Association

Wuraola Dosumu Market
Kogi Cluster Association

Lacasadbils

Lagoon Plaza Association

Lagos Plaza Committee of Traders

MA Dallas United Federal Association

Magodo Market

Mandelas United Traders Association

Niger 1234 Cluster Association

Oba Elegushi Market Association

Obanibasiri Market

Ogba Retail Market

Ogungbe Market

Oja Oba Provision Association

Ojomu Royal Market Association

Oke Arin Market Association

Oko Awo Market Association

Oleleye market

Olorunsogo

Omenukho Market Association

Onipetesi Community

Oniru Market Provisions/Toiletries Association

Opticians Association

Oroyinyin Traders Association

Otigba Association

Owolewa Plaza Association

Oyo Cluster Meeting

Peace Plaza Association

Phone Accessories Association

Phone Union Association

Plateau Cluster Association

Powa Plaza Phase 3 Association

Progress Plaza Association

Qubest Plaza Union

Radio Nigeria Plaza Association

Sabo Market

Samuis Plaza Landlord/Caretaker Association

Scapular Plaza Association

Seriki Market Association

Sokoto Plaza Association

Stationary Dealers Association

Taiwo Plaza Association

Temidire Plank Market

Turkish Product Finished Dealer Association

Under Bridge Open Market Berger

United Island Business Association

United Trader Association

Victoria Island Traders Association

White House Association

Wowo Oni Pala Association

Yisa Market 
Ziba Shoe Plaza Association

138
Zone B17 Plaza Association

. 


\section{B. APPENDIX TO CHAPTER 4}

Below are survey questions used in analyses in this dissertation.

\section{Trader surveys}

What is the main market or plaza association that you belong to? (survey 2)

Does the market association represent your interests? (surveys 1 \& 2)

Does the market association account properly for the fees it collects? (surveys 1 \& 2)

Do the association executives warn traders about specific dubious customers? (survey 2)

Do local government officials ever make surprise visits to ask you for fees? (survey 2)

Which ethnic group do you belong to? (surveys 1 \& 2)

What is the highest level of education you have completed? (surveys 1 \& 2)

Has this association had any lawsuit with local government since 2000? (survey 2)

Does [main market association name pre-filled] have an elected leader?" (survey 2)

Does the leader hold their position for life? (survey 2)

Do the association executives hold regularly scheduled meetings for traders? (survey 2)

Do the traders here share any of your customers? (survey 2)

Has your main supplier provided you with anything on credit in the past 6

months? (survey 2)

Is your main supplier Nigerian? (survey 2)

Which ethnic group does your main supplier belong to? (survey 2)

\section{Market association official survey}

In the past 10 years, has a market leader ever been dethroned against their will?

Who owns the land that this market is on?

For these executives you mentioned, do these positions have term limits? Or can individuals hold the position for life?

\section{Local government revenue collector survey}

Does the local government chairman involve himself in market association

leadership disputes? 


\section{BIBLIOGRAPHY}

Acemoglu, Daron and Simon Johnson. 2005. "Unbundling Institutions." Journal of Political Economy 113(5).

Acemoglu, Daron, Tristan Reed and James A Robinson. 2014. "Chiefs: Economic development and elite control of civil society in Sierra Leone." Journal of Political Economy 122(2):319-368.

Awam, James. 2014. Heirs of a heritage: Unconventional leadership strategies in Lagos. The James \& Solomons Company.

Baker, George, Robert Gibbons and Kevin J Murphy. 2002. "Relational Contracts and the Theory of the Firm." Quarterly Journal of economics pp. 39-84.

Baker, Pauline H. 1974. Urbanization and political change: the politics of Lagos, 1917-1967. Cambridge University Press.

Barkan, Joel D, Alex Gboyega and Mike Stevens. 2001. "State and Local Governance in Nigeria." World Bank Report .

Bates, Robert H. 1988. "Contra contractarianism: some reflections on the new institutionalism." Politics $\mathcal{E}$ Society 16(2-3):387-401.

Bates, Robert H. 1998. Analytic narratives. Princeton University Press.

Bates, Robert H. and Da-Hsiang Donald Lien. 1985. "A note on taxation, development, and representative government." Politics and Society 14(1):53-70.

Benjamin, Nancy, Kathleen Beegle, Francesca Recanatini and Massimiliano Santini. 2014. "Informal Economy and the World Bank." World Bank Policy Research Working Paper.

Berman, Sheri. 1997. "Civil society and the collapse of the Weimar Republic." World Politics 49(03):401-429.

Brady, Henry E and David Collier. 2010. Rethinking social inquiry: Diverse tools, shared standards. Rowman \& Littlefield Publishers. 
Bretherton, Luke. 2014. Resurrecting Democracy. Cambridge University Press.

Centeno, Miguel Angel. 2003. Blood and debt: War and the nation-state in Latin America. Penn State Press.

Cervero, Rober and Aaron Golub. 2011. Informal public transport: A global perspective. In Urban transport in the developing world: A handbook of policy and practice, ed. Harry T. Dimitriou and Ralph Gakenheimer. Cheltenham, UK: Edward Elgar.

Cleary, Matthew R. 2007. "Electoral competition, participation, and government responsiveness in Mexico." American Journal of Political Science 51(2):283-299.

Collier, David. 2011. "Understanding process tracing." PS Political science and politics 44(4):823.

Cross, John Christopher. 1998. Informal politics: Street vendors and the state in Mexico City. Stanford University Press.

de Gramont, Diane. 2014. Constructing the Megacity: The dynamics of state-building in Lagos, Nigeria, 1999-2013. Unpublished masters thesis.

de Gramont, Diane. 2015. Governing Lagos: Unlocking the Politics of Reform. Technical report Carnegie Endowment for International Peace.

Doner, Richard F. 1992. "Limits of state strength: toward an institutionalist view of economic development." World Politics 44(03):398-431.

Duggan, Catherine. Forthcoming. The Institutional Foundations of Lending: Indirect Regulation and State-Building. Cambridge University Press.

Easterly, William and Ross Levine. 1997. "Africa's growth tragedy: policies and ethnic divisions." The Quarterly Journal of Economics 112(4):1203-1250.

Edwards, Jeremy and Sheilagh Ogilvie. 2012. "What Lessons for Economic Development can we Draw from the Champagne Fairs?" Explorations in Economic History 29(2):131-148.

Ellickson, Robert. 1991. Order Without Law: How Neighbors Settle Disputes. Harvard University Press.

Evans, Peter B. 1989. Predatory, developmental, and other apparatuses: a comparative political economy perspective on the third world state. In Sociological Forum. Vol. 4 Springer pp. 561-587.

Evans, Peter B. 1995. Embedded autonomy: States and industrial transformation. Cambridge University Press. 
Fafchamps, Marcel. 1996. "The enforcement of commercial contracts in Ghana." World Development 24(3):427-448.

Fearon, James D and David D Laitin. 1996. "Explaining interethnic cooperation." American Political Science Review pp. 715-735.

Folami, Takiu. 1982. A History of Lagos, Nigeria: The Shaping of an African City. Exposition Press.

Frye, Timothy. 2000. Brokers and bureaucrats: Building market institutions in Russia. University of Michigan Press.

Frye, Timothy and Andrei Yakovlev. 2016. "Elections and Property Rights A Natural Experiment From Russia." Comparative Political Studies p. 0010414015621074.

Gafari, M. O. 1996. Market Women Association in the Administration of Markets. Sico International.

Gambetta, Diego. 1996. The Sicilian Mafia: The business of private protection. Harvard University Press.

Gandhi, Jennifer and Ellen Lust-Okar. 2009. "Elections under authoritarianism." Annual Review of Political Science 12:403-422.

Geddes, Barbara. 1994. Politician's dilemma: Building state capacity in Latin America. University of California Press.

Goertz, Gary and James Mahoney. 2012. A tale of two cultures: Qualitative and quantitative research in the social sciences. Princeton University Press.

Greif, Avner. 1993. "Contract Enforceability and Economic Institutions in Early Trade: The Maghribi Traders' Coalition." The American Economic Review 83(3):pp. 525-548.

Greif, Avner. 2006. Institutions and the Path to the Modern Economy. Cambridge University Press.

Haber, Stephen. 2006. "Authoritarian government.".

Habyarimana, James P. 2009. Coethnicity: Diversity and the Dilemmas of Collective Action. Russell Sage Foundation.

Holland, Alisha C. 2014. "The Distributive Politics of Enforcement." American Journal of Political Science . 
Ivaldi, Marc, Bruno Jullien, Patrick Rey, Paul Seabright and Jean Tirole. 2007. The economics of tacit collusion: Implications for merger control. In The Political Economy of Antitrust, ed. Vivek Ghosal and Johan Stennek. Amsterdam, The Netherlands: Elsevier.

Johnson, Cheryl Jeffries. 1978. Nigerian Women and British Colonialism: The Yoruba Example with Selected Biographies PhD thesis Northwestern University.

Johnson, Cheryl P. 1982. "Grassroots Organizing: Women in Anticolonial Activity in Southwestern Nigeria." African Studies Review 25(2-3):137-157.

Kang, David C. 2002. Crony capitalism: Corruption and development in South Korea and the Philippines. Cambridge University Press.

Lagos Urban Transport Project Implementation Completion and Results Report. 2011.

LeBas, Adrienne. 2013. "Violence and urban order in Nairobi, Kenya and Lagos, Nigeria." Studies in Comparative International Development 48(3):240-262.

Leeson, Peter T. 2007. "An-arrgh-chy: The Law and Economics of Pirate Organization." Journal of Political Economy 115(6):1049-1094.

Levi, Margaret. 1989. Of rule and revenue. University of California Press.

Lindsay, Lisa A. 1999. "Domesticity and difference: Male breadwinners, working women, and colonial citizenship in the 1945 Nigerian General Strike." American Historical Review pp. 783-812.

Luong, Pauline Jones and Erika Weinthal. 2004. "Contra coercion: Russian tax reform, exogenous shocks, and negotiated institutional change." American Political Science Review 98(о1):139-152.

Mabogunje, Akin L. 1964. "The evolution and analysis of the retail structure of Lagos, Nigeria." Economic Geography pp. 304-323.

MacLeod, W Bentley. 2007. "Reputations, relationships, and contract enforcement." Journal of economic literature pp. 595-628.

Malesky, Edmund and Paul Schuler. 2010. "Nodding or needling: Analyzing delegate responsiveness in an authoritarian parliament." American Political Science Review 104(03):482-502.

Markus, Stanislav. 2012. "Secure Property as a Bottom-Up Process: Firms, Stakeholders, and Predators in Weak States." World Politics 64(2):242-277. 
Markus, Stanislav. 2015. Property, Predation, and Protection: Piranha Capitalism in Russia and Ukraine. Cambridge University Press.

Marx, Benjamin, Thomas M Stoker and Tavneet Suri. 2013. "The Political Economy of Ethnicity and Property Rights in Slums: Evidence from Kenya.".

McMillan, J. and C. Woodruff. 1999. "Dispute Prevention Without Courts in Vietnam." Journal of Law, Economics, and Organization 15(3):637-658.

Meng, Tianguang, Jennifer Pan and Ping Yang. 2014. "Conditional Receptivity to Citizen Participation Evidence From a Survey Experiment in China." Comparative Political Studies p. 0010414014556212.

Migdal, Joel S. 1988. Strong societies and weak states: state-society relations and state capabilities in the Third World. Princeton University Press.

Miguel, Edward and Mary Kay Gugerty. 2005. "Ethnic diversity, social sanctions, and public goods in Kenya." Journal of public Economics 89(11):2325-2368.

Milgrom, Paul, Douglass North and Barry Weingast. 1990. “The Role of Institutions in the Revival of Trade: The Law Merchant, Private Judges, and the Champagne Fairs." Economics and Politics 2(1):1-23.

Mitlin, Diana. 2008. "With and beyond the state: Co-production as a route to political influence, power and transformation for grassroots organizations." Environment and Urbanization 20(2):339-360.

Murtazashvili, Ilia. 2013. The political economy of the American frontier. Cambridge University Press.

North, Douglass Cecil, John Joseph Wallis and Barry R Weingast. 2009. Violence and social orders: a conceptual framework for interpreting recorded human history. Taylor \& Francis.

North, Douglass Cecil et al. 1981. "Structure and change in economic history.".

Office of State Auditor General. 2012. “2012 Audit report of Local Government and Local Council Development Areas in Lagos State.".

Ogilvie, Sheilagh. 2014. "The Economics of Guilds." The Journal of Economic Perspectives pp. 169-192.

Olson, Mancur. 200o. Power and prosperity: Outgrowing communist and capitalist dictatorships. Basic Books. 
Ostrom, Elinor. 1990. Governing the commons: The evolution of institutions for collective action. Cambridge university press.

Oyemakinde, Wale. 1973. "The Pullen Marketing Scheme: A Trial in Food Price Control in Nigeria, 1941-1947." Journal of the Historical Society of Nigeria pp. 413423 .

Peil, Margaret. 1991. Lagos: The city is the people. GK Hall.

Polanyi, Karl. 1944. The great transformation: The political and economic origins of our time. Beacon Press.

Prag, Ebb. 2010. “Entrepot Politics: Political Struggles over the Dantokpa Marketplace in Cotonou, Benin." Danish Institute for International Studies Working Paper.

Rapson, R. N. 1959. Report of an Inquiry by Mr. R. N. Rapson, M.V.O., into alleged irregularities by the Lagos Town Council in connection with the collection of money and the issue of permits and the allocation of market stalls in respect of proposed temporary markets at Ereko and Oko-Awo. Technical report Federation of Nigeria.

Richman, Barak D. 2006. "How community institutions create economic advantage: Jewish diamond merchants in New York." Law E Social Inquiry 31(2):383-420.

Robinson, Amanda. 2015. "Internal Borders: Ethnic Diversity and Market Segmentation in Malawi." Working Paper .

Samii, Cyrus. 2013. "Who wants to forgive and forget? Transitional justice preferences in postwar Burundi." Journal of Peace Research p. 0022343312463713.

Schaeffer, Emily C. 2008. "Remittances and reputations in hawala money-transfer systems: Self-enforcing exchange on an international scale." Journal of Private Enterprise 24(Fall 2008):95-117.

Schneider, Friedrich. 2005. "Shadow economies around the world: what do we really know?" European Journal of Political Economy 21(3):598-642.

Shleifer, Andrei and Robert W Vishny. 1993. "Corruption." The Quarterly Journal of Economics 108(3):599-617.

Skarbek, David. 2014. The social order of the underworld: How prison gangs govern the American penal system. Oxford University Press.

Sklar, Richard L. 2004. Nigerian political parties: Power in an emergent African nation. Africa World Press. 
Stringham, Edward Peter. 2015. Private governance: Creating order in economic and social life. Oxford University Press.

Taylor, Curtis R and Steven N Wiggins. 1997. "Competition or compensation: Supplier incentives under the American and Japanese subcontracting systems." The American Economic Review pp. 598-618.

Thachil, Tariq. 2015. "Does Police Repression Increase Cooperation between Migrants? A Study of Informal Urban Marketplaces in India." A Study of Informal Urban Marketplaces in India (August 13, 2015).

Tilly, Charles. 1992. Coercion, capital, and European states, AD 990-1992. Blackwell Oxford.

Tsai, Lily L. 2007. Accountability without democracy: Solidary groups and public goods provision in rural China. Cambridge University Press.

Uzzi, Brian. 1996. "The sources and consequences of embeddedness for the economic performance of organizations: The network effect." American Sociological Review pp. 674-698.

Weeks, Jessica L. 2008. "Autocratic audience costs: Regime type and signaling resolve." International Organization 62(01):35-64.

Weingast, Barry R. 1995. "The economic role of political institutions: marketpreserving federalism and economic development." Journal of Law, Economics, $\mathcal{E}$ Organization pp. 1-31.

Williamson, Oliver E. 1983. "Credible commitments: Using hostages to support exchange." The American Economic Review pp. 519-540.

World Bank. 2007. "World Bank Enterprise Surveys.".

World Bank. 2010. “Guatemala Enterprise Informal Survey Implementation Note.".

World Bank. 2014. "Doing Business 2015: Going Beyond Efficiency.". 